Portland State University

PDXScholar

$12-18-2020$

\title{
Pharmaceuticals and Personal Care Products in Pacific Northwest Coastal Ecosystems: Spatial Variation, Organism Effects, and Consumer Perspectives
}

Amy Lynne Ehrhart

Portland State University

Follow this and additional works at: https://pdxscholar.library.pdx.edu/open_access_etds

Part of the Environmental Health Commons, Environmental Sciences Commons, and the Toxicology Commons

Let us know how access to this document benefits you.

\section{Recommended Citation}

Ehrhart, Amy Lynne, "Pharmaceuticals and Personal Care Products in Pacific Northwest Coastal Ecosystems: Spatial Variation, Organism Effects, and Consumer Perspectives" (2020). Dissertations and Theses. Paper 5661.

https://doi.org/10.15760/etd.7533

This Dissertation is brought to you for free and open access. It has been accepted for inclusion in Dissertations and Theses by an authorized administrator of PDXScholar. Please contact us if we can make this document more accessible: pdxscholar@pdx.edu. 
Pharmaceuticals and Personal Care Products in Pacific Northwest Coastal Ecosystems:

Spatial Variation, Organism Effects, and Consumer Perspectives

by

Amy Lynne Ehrhart

A dissertation submitted in partial fulfillment of the requirements for the degree of

Doctor of Philosophy

in

Earth, Environment and Society

Dissertation Committee:

Elise F. Granek, Chair

Catherine de Rivera

Elena Nilsen

Steven S. Rumrill

Amy Lubitow

Portland State University

2021 


\begin{abstract}
Anthropogenic pollution poses a threat to marine organisms and ecosystems worldwide. Common chemical pollutants that enter the marine environment include legacy contaminants, which are well known and heavily regulated or banned pollutants, and emerging contaminants, which are more recently recognized as pollutants and often lack regulatory limits for their use and discharge. Wastewater treatment plant (WWTP) effluent is a major source of various contaminants of concern, particularly pharmaceutical and personal care products (PPCPs) that are not fully removed during treatment. PPCPs exist at low concentrations in the environment and may have unknown and subtle effects on marine life. Data gaps exist on occurrence, effects, and remediation options, especially in coastal areas with low surrounding populations. Additionally, few studies focus on environmentally relevant conditions and organism, population and ecosystem level impacts.

The overarching goal of my dissertation research is to examine unexplored aspects of PPCP occurrence, effects, and pollution reduction in the Pacific Northwest. Through a field experiment, I compared PPCP accumulation in and health of Pacific oysters transplanted near WWTP outfalls and aquaculture areas in OR and WA. I also examined small-scale spatial variation in PPCP occurrence and effects along a pollution gradient near those outfalls. To identify organismal effects of PPCP mixtures on oysters, I designed and carried out a lab experiment exposing oysters to environmentally relevant concentrations of effluent from two OR coastal WWTPs. I measured growth, health, and feeding rate over a 12-week exposure period. I also compared PPCP detections and
\end{abstract}


concentrations in effluent from both WWTPs and oyster tissues after effluent exposure. Lastly, I explored a potential opportunity for reducing pharmaceutical pollution with improved drug disposal practices through use and establishment of drug take-back boxes in pharmacies. I conducted surveys with pharmacy customers, interviews with pharmacists, and a focus group with other pharmacy professionals regarding drug disposal behaviors, recommendations, and obstacles.

In the field experiment, two pharmaceuticals (miconazole and virginiamycin M1) and four alkylphenols (NP1EO, NP2EO, NP and OP) were detected at low concentrations relative to other studies. Alkylphenols and virginiamycin were detected at one oyster aquaculture site indicating potential for human exposure. Oyster condition was highest at one aquaculture site, compared to other aquaculture and wastewater sites. During the 12week lab experiment, effluent exposure had some effects on oyster growth and feeding rate, but concentration level $(10 \%, 25 \%, 50 \%)$ did not drive these differences. Three alkylphenols and 30 PPCPs were detected in effluent, and four alkylphenols and 13 PPCPs were detected in oyster tissues. Despite the lack of effects observed, oysters accumulated several PPCPs in their tissues. Through customer surveys I found awareness and use of drug take-back boxes was low, but marginally improved at locations with an onsite dropbox. Pharmacist recommendations at locations with drug take-back boxes were more consistent and safe compared to locations without dropboxes. Focus group participants emphasized the importance of increasing drug take-back box locations in OR through legislative action to address improper disposal. This research fills important data 
gaps on PPCP occurrence in WWTP effluent and accumulation in shellfish, organismal effects of PPCP mixtures, and possible pollution reduction options. 


\section{Acknowledgements}

I have many people to thank for their support during the past five years. First of all, I would like to thank my advisor, Dr. Elise Granek, for mentorship, recommendations, networking, and contributions to study design, data collection, draft editing, and publishing of my research. I would like to acknowledge the encouragement, patience, and ample feedback from my committee: Dr. Elise Granek, Dr. Cat de Rivera, Dr. Elena Nilsen, Dr. Steve Rumrill, and Dr. Amy Lubitow. These incredibly intelligent and dedicated individuals challenged and supported me and were a crucial part of framing and improving my dissertation studies. They helped me become a better scientist and I am forever grateful for this.

My research resulted from a collaborative effort and I am beholden to several research partners who assisted with study design and field/lab work. I would like to thank staff from Oregon Department of Fish and Wildlife, the South Slough National Estuarine Research Reserve, and the Whiskey Creek Shellfish Hatchery for consultation on study design, grant collaboration, boat transportation, and providing lab space. This research would not have been possible without the help of these partners, and the many field and lab volunteers that assisted with my research. In particular, I would like to thank Sabra Comet, Ashley Vizek, Patrick Blanchard, Marko Bradley, Anna Bolm, Corinne Heath, Kat Maloney, Abie Ilias, Arlene Amaya and Clare Homer who all helped for multiple long days in the field and lab, trudging through mudflats, doing tank water changes, and recording endless oyster dimensions. I would like to thank Lauren McKinney-Wise for using her awesome GIS skills to make maps of my field sites. Lastly, I thank current and 
former members of the Applied Coastal Ecology lab for feedback on all aspects of my research.

During my time as a student in the Portland State University Environmental Science and Management (ESM) department, I have received a lot of help from staff and faculty. I would like to thank Emma Spadaro and Sherie Huffman for answering countless questions and requests in person and via email. Kale Clauson fixed lab equipment that allowed me to complete experimental work in the lab, which I greatly appreciate. Dr. Becca Wilson-Ounekeo assisted with equipment coordination so I could finish my last year of lab work. Many faculty members provided advice and mentorship that improved my research, especially Dr. Yangdong Pan who gave feedback on data analysis, Dr. Cat de Rivera who had an open door to discuss research ideas and let me use her lab equipment, and Dr. Max Nielsen-Pincus who provided essential social science expertise for chapter 4. The ESM department provided four years of graduate teaching assistant funding that allowed me to focus on my studies without seeking outside employment and teach many graduate and undergraduate students, which was the most rewarding part of my $\mathrm{PhD}$ experience. I would like to thank the many teaching mentors that helped me become a better educator: Dr. Arick Rouhe, Dr. Yangdong Pan, Dr. Kelly Gleason, Dr. Amy Larson, Jaime Wood, and others.

Completing a $\mathrm{PhD}$ takes a village, and I am forever grateful to my graduate student peers, friends, and family for their support. The first years of my $\mathrm{PhD}$ were particularly difficult as I navigated the heavy workload and multiple obligations of adjusting to graduate school and figuring out my path for the next several years. I would 
like to thank Casey Lewis for trudging through those early years by my side and encouraging me to maintain work life balance. I would like to thank the $\mathrm{PhD}$ students that provided both sage advice and emotional support, particularly Dr. Tim Elder, Dr. Monica Mogilewsky, Dr. Britta Baechler, and Dorothy Horn. I would like to thank the Association of Environmental Science Students (AESS) for giving me a non-research avenue to volunteer and have fun (e.g, AESS softball team, happy hours, etc.). Thanks to the graduate student peers who made some of the hardest years of my life include the best memories and friendships. Along with those listed above, I thank Jaclyn Teixeira, Brian McGann, Whitney McClees, Crysta Gantz, Alex Bienko, Amy Hemingway, Bryn Hudson, Kaegan Scully-Engelmeyer and many others. I want to thank my friends and family for always being an anchor in the non-academic world and reminding me who I am outside of my academic accomplishments, especially my mom, Marsha Christoffersen, my dad, Brien Christoffersen, my aunt, Cori Facer, and my dear friends, Jackie Pendleton and Ashley Kerbs.

Lastly, I want to extend the most gratitude to my husband, Blaine Ehrhart, for his unwavering support, patience, and love. I wouldn't be where I am today without him. 


\section{Table of Contents}

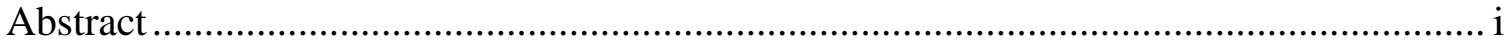

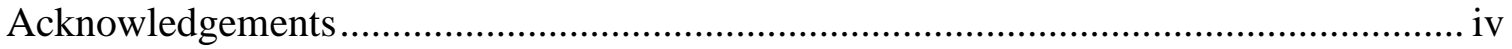

List of Tables .................................................................................................. ix

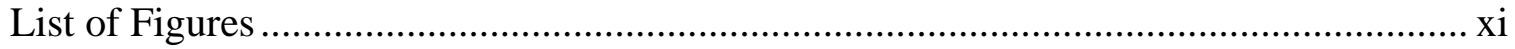

Preface

Chapter 1: Introduction .......................................................................................... 1

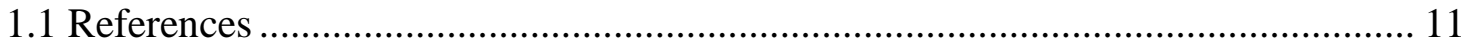

Chapter 2: Pharmaceuticals and alkylphenols in transplanted Pacific oysters (Crassostrea gigas): spatial variation and growth effects .................................................................. 18

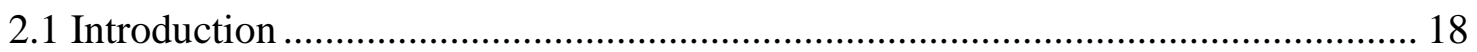

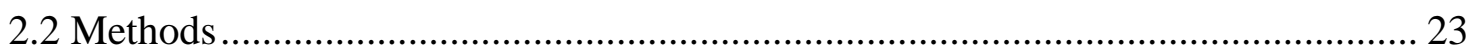

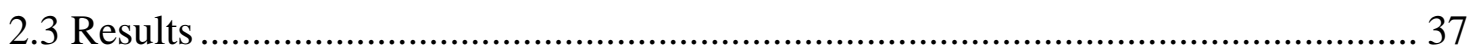

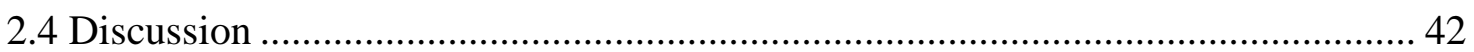

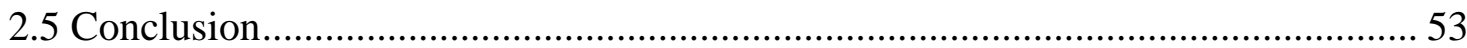

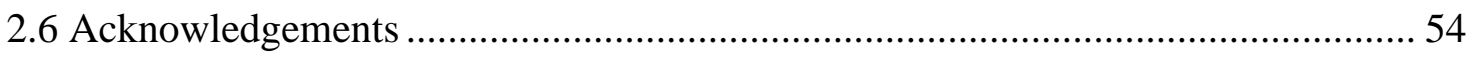

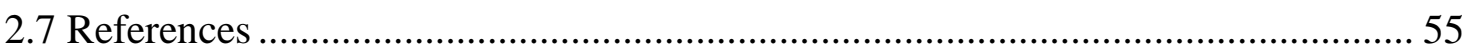

Chapter 3: PPCPs in coastal wastewater treatment plant effluent and effects on Pacific

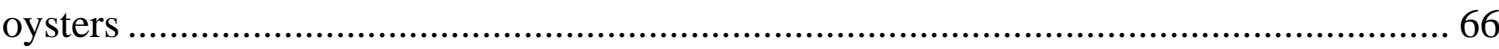

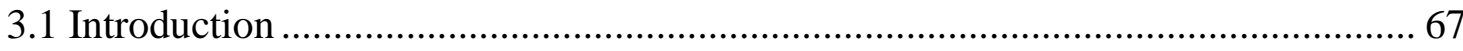

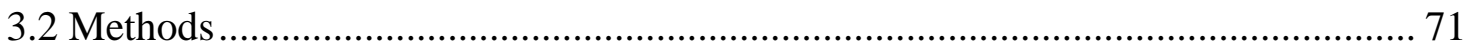

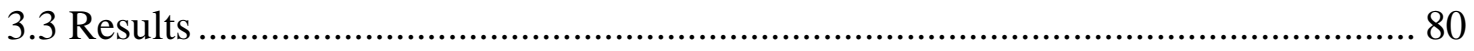

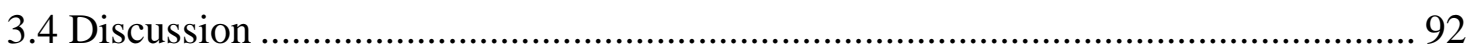

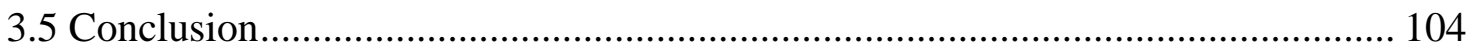

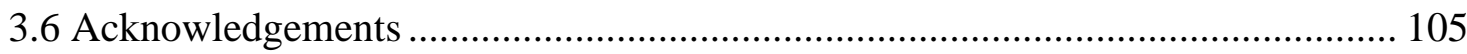

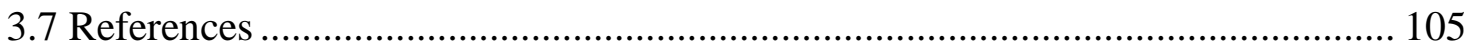

Chapter 4: Leftover drug disposal: customer behavior, pharmacist recommendations, and obstacles to drug take-back box implementation........................................................ 120

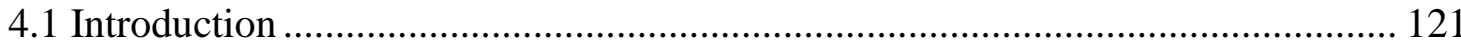

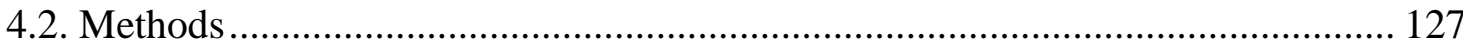

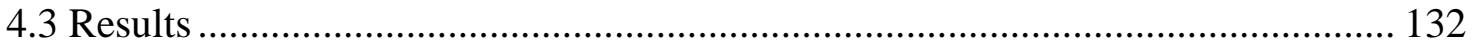

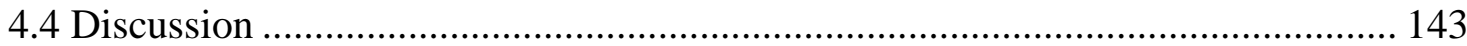

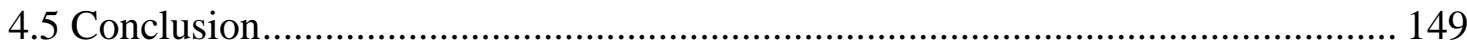

4.6 Acknowledgements ................................................................................. 150 


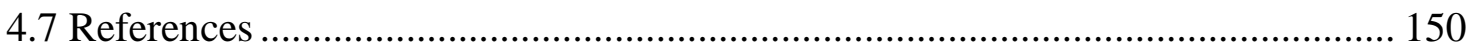

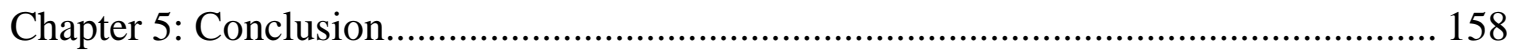

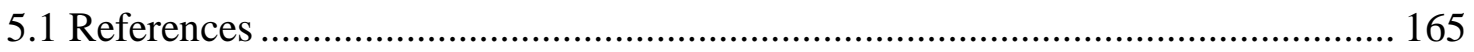

Appendix A: Supporting tables, figures, and information for chapter 2 ..................... 167

Appendix B: Supporting tables, figures, and information for chapter 3 ..................... 175

Appendix C: Supporting tables, figures, and information for chapter 4 ....................... 178

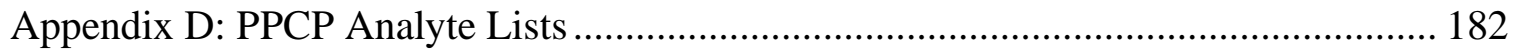




\section{List of Tables}

Chapter 2 Tables

Table 2.1 Characteristics of study estuaries in OR and WA 24

Table 2.2 Wastewater treatment plant characteristics at study sites in Coos Bay and North

Bend...... 26

Table 2.3 Concentrations of pharmaceuticals detected in April 2017 oyster tissues at wastewater sites (Coos, North Bend) and oyster growout sites (Westport, Netarts, Valino Island)

Table 2.4 Concentration of alkylphenols detected in July 2017 oyster tissues at all sites sampled: wastewater (Coos, North Bend) and oyster growout (Westport, Netarts, Valino Island)

Table 2.5 Summary of condition index and oyster dimensions for 50 randomly selected oysters from all racks within each site.

Table 2.6 Summary of condition index and oyster dimensions for one-year transplanted Pacific oysters collected in July 2017 41

Table 2.7 Concentrations of pharmaceuticals and alklyphenols in marine organism tissues reported in recent literature in nanograms per gram on a wet weight basis (ng/g ww).... 44

Chapter 3 Tables

Table 3.1 Summary statistics (mean and standard deviation) of oyster dimensions for each treatment at three sampling dates

Table 3.2 Summary statistics (mean and standard deviation) for change in oyster mass

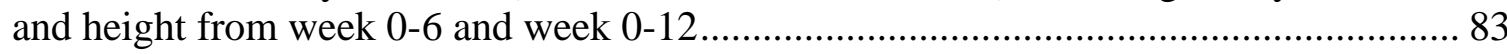

Table 3.3 Statitistical summary for two-way mixed ANOVA on oyster growth, wet tissue weight, and condition index 83

Table 3.4 Statistical summary for one-way ANOVA and t-tests on oyster feeding rate at each sampling week among treatments (control, 10\%, 25\%, 50\% (grab) effluent) ........ 84

Table 3.5 Concentrations of PPCPs and alkylphenols detected in composite wastewater treatment plant effluent.

Table 3.6 Concentrations of pharmaceuticals and alkylphenols detected in freeze-dried oyster tissues from controls and $25 \%$ effluent exposures from both treatment plants after 12 weeks of exposure 
Table 3.7 Results of power analysis for each variable from WWTP1 and WWTP2 based on three treatments $(0 \%, 10 \%$, and $25 \%$ effluent $)$

\section{Chapter 4 Tables}

Table 4.1 Pharmaceutical disposal recommendations from federal agencies in the United

States

Table 4.2 Demographic information of survey respondents.................................... 132

Table 4.3 Responses to multiple-choice customer survey questions at locations with and without dropboxes.

Table 4.4 Pharmacist responses to open-ended phone interview question regarding pros and cons of drug take-back programs at locations with $(n=9)$ and without $(n=20)$

dropboxes. 140 


\section{List of Figures}

\section{Chapter 2 Figures}

Figure 2.1 Map of estuaries on the OR and WA coast where study sites were set up (indicated by circles and large labels)

Figure 2.2 Schematic of field design for sites with a wastewater treatment plant outfall and picture of oyster racks with bags of juvenile oysters settled on nonliving oyster shells

Figure 2.3 Map of study sites and set up of oyster racks at each wastewater and oyster growout site

Figure 2.4 Condition index of one-year transplanted Pacific oysters collected in July 2017 compared at all sites (A), and at racks within each site for Coos Bay (B), North Bend (C), Valino Island (D), Netarts Bay (E), and Westport, WA (F) ..................................... 42

\section{Chapter 3 Figures}

Figure 3.1 Schematic of experimental design for effluent exposure lab study where oysters were exposed to composite (c) and grab (g) samples of effluent at concentrations of 10,25 , and $50 \%$ effluent.

Figure 3.2 Boxplots of change in oyster mass and shell height after exposure to effluent $(10 \%, 25 \%, 50 \%)$ from two wastewater treatment plants and a seawater control $(0 \%)$ from 0-6 weeks and 0-12 weeks

Figure 3.3 Boxplots of oyster wet tissue weight and condition index after exposure to effluent from two wastewater treatment plants and a seawater control $(0 \%)$, sampled at three time points $(0,6$, and 12 weeks $)$

Figure 3.4 Boxplots of oyster feeding rates (measured as algal clearance) after exposure to effluent from two wastewater treatment plants and a seawater control $(0 \%)$, sampled at three time points $(6,7$ and 12 weeks)

\section{Chapter 4 Figures}

Figure 4.1 Percent of pharmacists that recommended each type of disposal method to customers at locations with $(n=9)$ and without $(n=20)$ dropboxes 


\section{Preface}

Chapters 2, 3, and 4 will be submitted to or have been published in peer-reviewed journals and therefore may contain some repetition of introductory material. To comply with journal expectations, I use "we" in these chapters to include partners and co-authors. Personal reflections on field and lab experiences are included in Appendix A4 and B2. 


\section{Chapter 1: Introduction}

Coastal ecosystems provide a multitude of benefits to both humans and marine species yet are among the most heavily impacted marine environments (Millennium Ecosystem Assessment 2005). Human populations near the ocean are consistently growing and approximately $10 \%$ of the global population resides in coastal zones below

$10 \mathrm{~m}$ of elevation (Neumann et al. 2015). In the United States, $40 \%$ of people live within 60 miles of the coast (NOAA Office for Coastal Management 2016). With growing populations, human impacts from habitat loss, eutrophication, fisheries, pollution and global climate change are having negative and potentially irreversible effects on marine environments (Crain et al. 2009). All of these factors can impact organisms and ecosystems as stressors, defined as environmental influences that interfere with the function of an ecosystem (Breitburg and Riedel 2005) and/or impair structure and function of organisms resulting in reduced fitness (Calow 1989). Organisms and ecosystems respond to stress in one of two ways: resistance, defined as the ability to withstand disturbance/stress, and resilience, the capacity to recover from and return to a stable state (Pimm 1984). Given that many of these variables occur simultaneously, it is important to consider the cumulative effects of multiple stressors, which may be additive $($ effect $=A+B)$, synergistic $($ effect $>A+B)$, or antagonistic $($ effect $<A+B)($ Folt et al. 1999).

Pollution is considered one of the top threats to coastal ecosystems (Crain et al. 2009). For centuries the ocean has served as a sink for solid waste, sewage, chemical discharge, excess nutrients, oil, and other pollutants. Two major categories of chemical 
contaminants are found in marine environments: legacy and emerging contaminants. Legacy contaminants include compounds that are currently banned, or heavily regulated but continue to persist in the environment, such as polychlorinated biphenyls (PCBs), heavy metals, and legacy pesticides such as dichlorodiphenyltrichloroethane (DDT). In contrast, contaminants of emerging concern (CECs) are more recently recognized as pollutants and have little regulation in their use or discharge (US EPA 2008). Some examples include pharmaceutical and personal care products (PPCPs), polybrominated diphenyl ethers (PBDEs), endocrine disrupting chemicals (EDCs), and most current use pesticides (US EPA 2008). In the United States (US), contaminants are regulated by the 1976 Toxic Substances Control Act (TSCA) which allows the US Environmental Protection Agency to prevent environmental pollution by requiring and overseeing evaluation of risks of these substances (Schierow 2009). If a chemical is deemed potentially harmful to humans or the environment, the EPA may require the manufacturer to test the chemical for environmental impacts (Schierow 2009). With tens of thousands of chemicals on the market, only a few are heavily scrutinized. In addition, most CECs, such as drugs and personal care products, are not included in this legislation and therefore are not subject to assessment of environmental risks before or after production and release into the market (Schierow 2009).

There are many sources of contaminants to the coastal marine environment. Wastewater treatment plant (WWTP) and industrial effluent contain various CECs, particularly PPCPs, as most are not removed during the treatment process (Lara-Martín et al. 2014). Contaminants that readily bind to sediments during wastewater treatment may 
be redistributed when sludge is applied as fertilizer in agricultural settings, which frequently occurs with PPCPs (Gaw et al. 2014). Hospitals, veterinary facilities, and pharmaceutical manufacturers can be an important source of PPCPs to the environment as well (Daughton and Ternes 1999). CECs can leach into groundwater from failing or inadequately maintained septic systems which are commonly used in rural coastal areas (Gaw et al. 2014). Stormwater and agricultural runoff are large sources of CECs such as veterinary pharmaceuticals and pesticides. Landfill leachate can be a source of pharmaceuticals and other chemicals that are thrown away, especially if the landfill lacks proper lining and maintenance. Many chemicals bind to sediments in aquatic and marine environments and may be resuspended when perturbed, thus becoming a secondary source of contamination (Gaw et al. 2014).

Contaminants in the marine environment have the potential for bioaccumulation in organisms, or an increase in concentration within an organism. For some compounds, biomagnification may also occur, where organisms higher in the food chain (e.g., apex predators) contain elevated concentrations of contaminants from trophic transfer (Dodder et al. 2014). Many factors can affect the bioaccumulation and biomagnification potential of compounds, including individual chemical properties, surrounding environmental factors (e.g., $\mathrm{pH}$, salinity, temperature), and organism behavior, habitat, and trophic level. Compounds that are more hydrophobic/lipophilic tend to bioaccumulate more readily, while hydrophilic/lipophobic compounds are less likely to accumulate in organism tissues, though there are many exceptions to these general predictions and hydrophilic compounds can negatively affect organisms (e.g., (Oliveira et al. 2017). Higher pH 
values can increase the lipophilic nature of some chemicals (e.g., pharmaceuticals) by decreasing the amount that can ionize and dissociate in the surrounding water, indicating marine organisms may have a higher potential for bioaccumulation (Fabbri and Franzellitti 2016). At higher salinities, some chemicals bind to sediment more readily, which could make this a more significant source of contamination to the marine environment (Fabbri and Franzellitti 2016). Sessile and benthic organisms may have higher exposure to chemical contaminants due to inability to move long distances from sources and proximity to the sediment, indicating high potential for bioaccumulation. Organisms at higher trophic levels that consume benthic organisms are at highest risk for bioaccumulation, particularly those living in estuaries and nearshore environments. For example, (Gu et al. 2016) found higher concentrations of 4-nonylphenol, a surfactant with demonstrated endocrine disruption, in benthic mollusks compared to fish, and higher concentrations of other alkylphenols in fish that consumed benthic organisms compared to fish that do not consume benthic organisms.

PPCPs were first identified as environmental pollutants in the 1970s (e.g., (Hignite and Azarnoff 1977), but research on their occurrence and effects was not prominent in the literature until the late 1990s and early 2000s, when analytical methods were developed and improved to detect concentrations in the ng-ug/L range (Daughton and Ternes 1999). In 1999, Daughton and Ternes wrote the first publication calling for scientists to increase research focused on presence, effects, and potential environmental risk of PPCPs. Since then, hundreds of studies have characterized the occurrence of PPCPs in effluent, surface water, sediments, and animal tissues. Though fewer studies 
have focused on PPCPs in marine environments compared to freshwater (Mezzelani et al. 2018), research is increasing in this area with approximately 233 PPCPs being investigated worldwide in seawater, sediment, and animal tissue as of 2016 (Arpin-Pont et al. 2016). A more recent review of pharmaceuticals and their metabolites in seawater reported a total of 151 drugs detected in marine waters worldwide (Madikizela et al. 2020). Regionally, four studies on the U.S. West coast detected over 50 PPCPs in fish and bivalve tissues (Dodder et al. 2014; Granek et al. 2016; Meador et al. 2016; James et al. 2020). In general, PPCPs have lower bioaccumulative potential due to their high ionization properties and low lipophilicity yet are frequently found to accumulate in tissues of marine organisms. Higher $\mathrm{pH}$ and salinity in marine environments, along with other chemical and environmental factors, may contribute to this pattern. While most PPCPs are less persistent in the environment than legacy contaminants, consistent discharge from multiple sources leads to a constant presence of contaminants at low concentrations. This continual replenishment, or pseudo-persistence, exposes biota to a suite of potentially toxic compounds on a regular basis (Daughton and Ternes 1999). While consumer excretion has received the most attention as a source of pharmaceuticals in wastewater, household disposal of leftover medications can also contribute to the environmental presence of these compounds (Bound and Voulvoulis 2005). In the US, current recommendations for leftover drug disposal include flushing down the drain, throwing in the trash, and taking to semi-annual drug take-back events. The first two options pose environmental contamination risks, while the third presents a public health issue as stored drugs can end up being consumed by unintended users 
through illegal usage or accidental ingestion, potentially leading to overdose. Efforts to improve proper disposal of pharmaceuticals can alleviate public health concerns and partially address the issue of environmental contamination.

PPCPs are of particular concern in the marine environment due to their yearround use, widespread occurrence in populated coastal areas, and designed use in eliciting a biological response in organisms (Daughton and Ternes 1999; Fabbri and Franzellitti 2016). PPCPs are expected to have effects on organisms due to their modes of action (MOA), or specific pathways of producing a therapeutic effect in humans (Fabbri and Franzellitti 2016). Some receptors (e.g., tissues, organs, biomolecules) targeted by the MOA of certain drugs in humans exist in other vertebrates, with the majority of known targets identified in fish (Fent et al. 2006). It is expected that drugs would have similar effects on organisms with these pathways, which can be useful in predicting effects and designing ecotoxicological experiments. However, several drugs have multiple target pathways or unknown therapeutic mechanisms, making it difficult to use this approach (Daughton and Ternes 1999). Additionally, information about target pathways for human drugs is largely unknown in invertebrates (Fent et al. 2006).

Toxic effects of contaminants on organisms are typically identified by examining acute (short duration) and chronic (extended duration) toxicity endpoints and dose response curves that identify the lowest observed effect concentration (LOEC) and/or the concentration that results in 50\% mortality in a single exposure (LC50). Because they are present at such low concentrations (e.g., ng/L), traditional toxicity endpoints are not applicable to PPCPs (Daughton and Ternes 1999). The LOECs for pharmaceuticals tend 
to be in the $\mathrm{mg} / \mathrm{L}$ range, which is much higher than typical concentrations detected in wastewater effluent (Fent et al. 2006). Therefore, effects are more likely to be sublethal after chronic exposure to low levels for longer periods of time (Fent et al. 2006). Some effects have been observed in both freshwater and marine organisms under chronic exposure to environmentally relevant concentrations, but there is a paucity of research addressing the sublethal chronic effects of multiple PPCPs on marine organisms (Mezzelani et al. 2018).

A few PPCPs and many other CECs have been identified as endocrine disruptors (e.g., triclosan), or chemicals that interact with hormone receptors (Fagin 2012). Many of these compounds do not demonstrate a traditional dose response curve with more pronounced effects at higher concentrations and instead have non-monotonic responses where the curve changes from negative to positive or vice versa at some point during the exposure (Fagin 2012). In many cases, lower or mid-range concentrations have worse effects than high concentrations (e.g., Hayes et al. 2002; Jenkins et al. 2011). This pattern is emerging in more studies, including pharmaceuticals that are not considered endocrine disruptors. For example, two experiments that evaluated molecular and cellular level effects of pain medication (ibuprofen and acetaminophen) on Pacific oysters found more pronounced effects in the lowest concentrations of these drugs (Serrano et al. 2015; Bebianno et al. 2017), demonstrating the importance of including low, environmentally relevant concentrations of PPCPs in toxicological experiments.

Reducing PPCP pollution in marine and aquatic environments will require various interventions. For pharmaceuticals, there are several options to address both excretion 
and disposal. Studies have shown that adding tertiary treatment to wastewater treatment plants can improve the removal of PPCPs (Rout et al. 2021, Castiglioni et al. 2006; Ternes et al. 2003). These improvements to wastewater treatment technologies would likely be the most effective solution, but are the most impractical given the costs of adding them to facilities. Medical professionals can play a large role in reducing the amounts of drugs that are consumed, excreted, and disposed. For example, implementing sustainable prescription practices, which refers to prescribing the lowest effective dosage, choosing drugs types that degrade more readily, and considering the duration of treatment (Daughton and Ruhoy 2013) can play a role. Additionally, development of "green pharmaceuticals," or drugs that degrade quickly in the environment, is underway for a handful of drug types (Kummerer 2019), and could be effective if manufacturers are incentivized to participate (Straub 2016). Lastly, to address disposal of leftover drugs, convenient disposal options, such as drug take-back boxes in pharmacies, need to be implemented on a broader scale (Ehrhart et al. 2020). For personal care products, changes to public usage patterns may be helpful in reducing these loadings. Requirements for listing ingredients and risks on personal care and cleaning products, or including certifications that they are environmentally benign, such as the EPA Safer Choice label (US EPA 2020), combined with consumer education could reduce some chemical pollution from these products.

Several regional data gaps exist in the occurrence, effects and remediation of PPCPs in the marine environment. In the Pacific Northwest, there is a lack of occurrence data for PPCPs, particularly in coastal areas with small human populations, which 
represent most of the OR and WA coastlines. Additionally, Pacific Northwest estuaries have high tidal influence, short residence times, and are affected by seasonal upwelling in the summer (Lee II and Brown 2009), which may impact contaminant occurrence. Bioaccumulation and effects of direct exposure to effluent in bivalves has not been explored with effluent from WWTPs that serve small coastal populations. Lastly, the effectiveness of remediation strategies for disposed pharmaceuticals remains unknown. The research in this dissertation aims to fill some of these gaps by focusing on PPCP occurrence in estuaries in OR and WA, chronic effects on organisms, and leftover drug disposal practices and recommendations. In chapter 2, I investigated PPCP occurrence and small scale spatial variation near wastewater sources. To do this, I conducted a field experiment comparing PPCP accumulation in Pacific oysters transplanted near WWTP outfalls and oyster aquaculture. In chapter 3, I examined uptake and effects of PPCPs in coastal wastewater treatment plant effluent on oysters under environmentally relevant conditions. I conducted a lab experiment where oysters were exposed to low concentrations of effluent containing a complex mixture of PPCPs for 12 weeks. I measured organism level effects and concentrations of PPCPs in effluent and oyster tissue. In chapter 4, I explored the role of drug take-back boxes in proper drug disposal among consumers. I administered surveys to customers and interviewed pharmacists regarding disposal practices and recommendations, and compared results from pharmacy locations with and without drug take-back receptacles.

The results of this research show that PPCPs are present in marine environments with low coastal populations, oysters accumulate toxins in their tissues following 
exposure but show minimal organism-level effects, and drug take-back boxes in pharmacies may reduce pharmaceutical pollution from disposal. In chapter 2, I found that oysters in OR and WA accumulated two pharmaceuticals and four alkylphenols, but with fewer detections and lower concentrations compared to studies with higher surrounding populations. Concentrations were similar among sites indicating that proximity to wastewater did not drive differences at small spatial scales. In chapter 3, I also observed that oysters accumulated PPCPs from effluent, but at a higher rate than in the field. Specifically, there were 30 PPCPs detected in effluent, with 13 of those detected in the tissue. In chapters 2 and 3, exposure to wastewater had subtle effects on oysters. Oysters transplanted near wastewater had lower condition index than oysters at aquaculture sites. In the lab, oysters exposed to wastewater from one treatment plant experienced suppressed shell growth. In chapter 4, customers reported high rates of storing drugs at home and low awareness of drug take-back boxes, but this was marginally improved at locations with drug take-back boxes. Additionally, pharmacists at drug take-back box locations gave consistent and safe disposal recommendations, indicating that presence of a dropbox can improve drug disposal messaging to consumers. These results support legislative and funding efforts to increase drug take-back box presence in pharmacies for safe and convenient year-round disposal. Overall, the findings from my research address data gaps in occurrence, effects, and remediation options for PPCP pollution in the Pacific Northwest by reporting concentrations near sources in OR and WA, effects on and accumulation by bivalves, and consumer and pharmacist behaviors regarding drug disposal. 


\subsection{References}

Arpin-Pont L, Bueno MJM, Gomez E, Fenet H. 2016. Occurrence of PPCPs in the marine environment: a review. Environ Sci Pollut Res 23:4978-4991; doi:10.1007/s11356-014-3617-x.

Bebianno MJ, Mello ACP, Serrano MAS, Flores-Nunes F, Mattos JJ, Zacchi FL, et al. 2017. Transcriptional and cellular effects of paracetamol in the oyster Crassostrea gigas. Ecotoxicology and Environmental Safety 144:258-267; doi:10.1016/j.ecoenv.2017.06.034.

Bound JP, Voulvoulis N. 2005. Household Disposal of Pharmaceuticals as a Pathway for Aquatic Contamination in the United Kingdom. Environmental Health Perspectives 113:1705-1711; doi:10.1289/ehp.8315.

Breitburg DL, Riedel GF. 2005. Multiple stressors in marine systems. In: Marine Conservation Biology: the Science of Maintaining the Sea's Biodiversity. Island Press: Washington, DC. 167-182.

Calow P. 1989. Proximate and ultimate responses to stress in biological systems. Biol J Linn Soc 37:173-181; doi:10.1111/j.1095-8312.1989.tb02101.x.Castiglioni S, Bagnati R, Fanelli R, Pomati F, Calamari D, Zuccato E. 2006. Removal of Pharmaceuticals in Sewage Treatment Plants in Italy. Environmental Science \& Technology 40:357-363; doi:10.1021/es050991m. 
Crain CM, Halpern BS, Beck MW, Kappel CV. 2009. Understanding and Managing Human Threats to the Coastal Marine Environment. Annals of the New York Academy of Sciences 1162:39-62; doi:10.1111/j.1749-6632.2009.04496.x.

Daughton CG, Ternes TA. 1999. Pharmaceuticals and personal care products in the environment: agents of subtle change? Environ Health Perspect 107: 907-938.

Daughton C, Ruhoy I. 2013. Lower-dose prescribing: Minimizing "side effects" of pharmaceuticals on society and the environment. Science of The Total Environment 443:324-337; doi:10.1016/j.scitotenv.2012.10.092.

Dodder NG, Maruya KA, Lee Ferguson P, Grace R, Klosterhaus S, La Guardia MJ, et al. 2014. Occurrence of contaminants of emerging concern in mussels (Mytilus spp.) along the California coast and the influence of land use, storm water discharge, and treated wastewater effluent. Marine Pollution Bulletin 81:340-346; doi:10.1016/j.marpolbul.2013.06.041.

Ehrhart AL, Granek EF, Nielsen-Pincus M, Horn DA. 2020. Leftover drug disposal: Customer behavior, pharmacist recommendations, and obstacles to drug take-back box implementation. Waste Management 118:416-425; doi:10.1016/j.wasman.2020.08.038.

Fabbri E, Franzellitti S. 2016. Human pharmaceuticals in the marine environment: Focus on exposure and biological effects in animal species. Environ Toxicol Chem 35:799-812; doi:10.1002/etc.3131.

Fagin D. 2012. Toxicology: The learning curve. Nature News 490:462; doi:10.1038/490462a. 
Fent K, Weston AA, Caminada D. 2006. Ecotoxicology of human pharmaceuticals. Aquatic Toxicology 76:122-159; doi:10.1016/j.aquatox.2005.09.009.

Folt CL, Chen CY, Moore MV, Burnaford J. 1999. Synergism and antagonism among multiple stressors. Limnology and Oceanography 44:864-877; doi:10.4319/1o.1999.44.3_part_2.0864.

Gaw S, Thomas KV, Hutchinson TH. 2014. Sources, impacts and trends of pharmaceuticals in the marine and coastal environment. Philosophical Transactions of the Royal Society B: Biological Sciences 369:2013057220130572; doi:10.1098/rstb.2013.0572.

Granek EF, Conn KE, Nilsen EB, Pillsbury L, Strecker AL, Rumrill SS, et al. 2016. Spatial and temporal variability of contaminants within estuarine sediments and native Olympia oysters: A contrast between a developed and an undeveloped estuary. Science of The Total Environment 557-558:869-879; doi:10.1016/j.scitotenv.2016.03.043.

Gu Y, Yu J, Hu X, Yin D. 2016. Characteristics of the alkylphenol and bisphenol A distributions in marine organisms and implications for human health: A case study of the East China Sea. Science of The Total Environment 539:460-469; doi:10.1016/j.scitotenv.2015.09.011.

Hayes TB, Collins A, Lee M, Mendoza M, Noriega N, Stuart AA, et al. 2002. Hermaphroditic, demasculinized frogs after exposure to the herbicide atrazine at low ecologically relevant doses. PNAS 99:5476-5480; doi:10.1073/pnas.082121499. 
Hignite C, Azarnoff DL. 1977. Drugs and drug metabolites as environmental contaminants: Chlorophenoxyisobutyrate and salicylic acid in sewage water effluent. Life Sciences 20:337-341; doi:10.1016/0024-3205(77)90329-0.

James CA, Lanksbury J, Khangaonkar T, West J. 2020. Evaluating exposures of bay mussels (Mytilus trossulus) to contaminants of emerging concern through environmental sampling and hydrodynamic modeling. Science of The Total Environment 709:136098; doi:10.1016/j.scitotenv.2019.136098.

Jenkins S, Wang J, Eltoum I, Desmond R, Lamartiniere C. 2011. Chronic Oral Exposure to Bisphenol A Results in a Nonmonotonic Dose Response in Mammary Carcinogenesis and Metastasis in MMTV-erbB2 Mice. Environmental Health Perspectives 119:1604-1609; doi:10.1289/ehp.1103850.

Kümmerer K. 2019. From a problem to a business opportunity-design of pharmaceuticals for environmental biodegradability. Sustainable Chemistry and Pharmacy 12:100136; doi:10.1016/j.scp.2019.100136.

Lara-Martín PA, González-Mazo E, Petrovic M, Barceló D, Brownawell BJ. 2014. Occurrence, distribution and partitioning of nonionic surfactants and pharmaceuticals in the urbanized Long Island Sound Estuary (NY). Marine Pollution Bulletin 85:710-719; doi:10.1016/j.marpolbul.2014.01.022.

Lee II H, Brown CA. 2009. Classification of Regional Patterns of Environmental Drivers and Benthic Habitats in Pacific Northwest Estuaries. 
Madikizela LM, Ncube S, Tutu H, Richards H, Newman B, Ndungu K, et al. 2020.

Pharmaceuticals and their metabolites in the marine environment: Sources, analytical methods and occurrence. Trends in Environmental Analytical Chemistry 28:e0104; doi:10.1016/j.teac.2020.e00104.

Meador JP, Yeh A, Young G, Gallagher EP. 2016. Contaminants of emerging concern in a large temperate estuary. Environmental Pollution 213:254-267; doi:10.1016/j.envpol.2016.01.088.

Mezzelani M, Gorbi S, Regoli F. 2018. Pharmaceuticals in the aquatic environments: Evidence of emerged threat and future challenges for marine organisms. Marine Environmental Research 140:41-60; doi:10.1016/j.marenvres.2018.05.001. Millennium Ecosystem Assessment, ed. 2005. Ecosystems and human well-being: synthesis. Island Press:Washington, DC.

Neumann B, Vafeidis AT, Zimmermann J, Nicholls RJ. 2015. Future Coastal Population Growth and Exposure to Sea-Level Rise and Coastal Flooding - A Global Assessment. PLoS ONE 10:1-34; doi:10.1371/journal.pone.0118571.

NOAA Office for Coastal Management. 2016. Economics and Demographics. Fast Facts: Economics and Demographics. Available: http://coast.noaa.gov/states/fastfacts/economics-and-demographics.html [accessed 27 October 2020].

Oliveira P, Almeida Â, Calisto V, Esteves VI, Schneider RJ, Wrona FJ, et al. 2017. Physiological and biochemical alterations induced in the mussel Mytilus galloprovincialis after short and long-term exposure to carbamazepine. Water Research 117:102-114; doi:10.1016/j.watres.2017.03.052. 
Pimm SL. 1984. The complexity and stability of ecosystems. Nature 307:321-326; doi:10.1038/307321a0.

Schierow L-J. 2009. The Toxic Substances Control Act (TSCA): Implementation and New Challenges.

Serrano MA, S, Gonzalez-rey M, Mattos JJ, Flores-nunes F, Mello ÁC, et al. 2015. Differential gene transcription, biochemical responses, and cytotoxicity assessment in Pacific oyster Crassostrea gigas exposed to ibuprofen. Environmental Science and Pollution Research International; Heidelberg 22:17375-17385; doi:http://dx.doi.org.proxy.lib.pdx.edu/10.1007/s11356-0144023-0.

Straub JO. 2016. Reduction in the environmental exposure of pharmaceuticals through diagnostics, Personalised Healthcare and other approaches. A mini review and discussion paper. Sustainable Chemistry and Pharmacy 3:1-7; doi:10.1016/j.scp.2015.12.001.

Ternes TA, Stüber J, Herrmann N, McDowell D, Ried A, Kampmann M, et al. 2003. Ozonation: a tool for removal of pharmaceuticals, contrast media and musk fragrances from wastewater? Water Research 37:1976-1982; doi:10.1016/S00431354(02)00570-5.

US EPA. 2008. White Paper: Aquatic Life Criteria for Contaminants of Emerging Concern Part 1: General Challenges and Recommendations. Available: https://www.epa.gov/sites/production/files/201508/documents/white_paper_aquatic_life_criteria_for_contaminants_of_emerging_ 
concern_part_i_general_challenges_and_recommendations_1.pdf [accessed 29

October 2020].

US EPA. 2020. Learn About the Safer Choice Label. US EPA. Available:

https://www.epa.gov/saferchoice/learn-about-safer-choice-label [accessed 29

October 2020]. 


\title{
Chapter 2: Pharmaceuticals and alkylphenols in transplanted Pacific oysters (Crassostrea gigas): spatial variation and growth effects
} Under review in the peer-reviewed journal, Marine Pollution Bulletin.

\begin{abstract}
Pharmaceutical and personal care products in wastewater discharge can be stressors to estuarine species and ecosystems. We transplanted newly settled juvenile Pacific oysters (Crassostrea gigas) to sites near wastewater treatment plant outfalls and oyster aquaculture to assess small scale spatial variation in pharmaceutical and alkylphenol occurrence and oyster condition. Oysters were transplanted in July 2016 to sites in Coos and Netarts Bays, OR and Grays Harbor, WA, then collected after 9 (April) and 12 (July) months. Two pharmaceuticals (miconazole and virginiamycin M1) were detected in April samples and four alkylphenols (NP1EO, NP2EO, NP and OP) were detected in July samples, but concentrations were low relative to other studies. Both alkylphenols and virginiamycin were detected at one oyster growout site indicating potential for human exposure. Oyster condition was highest at another oyster growout site. This research fills important data gaps on contaminant accumulation in shellfish at sites exposed to wastewater discharge.
\end{abstract}

\subsection{Introduction}

Pharmaceutical and personal care products (PPCPs) include prescription, over the counter, and illicit drugs, antimicrobials, fragrances, preservatives, and surfactants (Lara- 
Martín et al. 2014). PPCPs are frequently detected in marine and aquatic environments worldwide and can enter the environment from multiple sources (Arpin-Pont et al. 2016). When pharmaceuticals are consumed, they are rarely fully metabolized by the body and therefore traces of medicines are excreted in human waste (Jjemba 2006). Leftover drugs are often disposed of by flushing down the sink or toilet (Ruhoy and Daughton 2007). Personal care products that are applied to the skin and washed off and surfactants in detergents and cleaners are commonly rinsed down the drain. Current wastewater treatment plant technologies do not fully remove most PPCPs (Vieno et al. 2007) resulting in regular discharge to the environment and continuous exposure of organisms to multiple chemical stressors. Other sources of PPCPs include veterinary facilities, hospitals, stormwater and industrial discharges, septic leakage, landfill leachate, and agricultural runoff (Gaw et al. 2014), but wastewater is considered the most prominent source of pharmaceuticals to aquatic and marine environments (Hughes et al. 2013). Pharmaceuticals are unique contaminants because they are designed to elicit a biological or therapeutic response in humans or other mammals at low doses (Fabbri and Franzellitti 2016). Due to potential biological effects, pharmaceutical presence in the environment is cause for particular concern. The pathway of a drug in the body, known as the mode of action, may be similar to humans for some aquatic species containing similar receptors or symbionts; for example, there are some known overlapping receptors present in fish (Fent et al. 2006). For other species, particularly invertebrates with very different physiological functions, potential effects of pharmaceuticals may be less clear (Fent et al. 2006). In general, pharmaceuticals have low risk for acute toxicity to marine organisms, 
but show effects under chronic exposure to low concentrations (Prichard and Granek 2016). For example, caffeine increases production of heat shock proteins, a sign of stress, in California mussels after 10-30 days of exposure (Rodriguez del Rey et al. 2011).

The US Food and Drug Administration (FDA) regulates environmental assessment of pharmaceuticals through the approval process of new drugs (US FDA 1998). An environmental assessment based on expected environmental concentrations, physical and chemical properties and mechanisms of breakdown of the drug is submitted by the manufacturer with the application (US FDA 1998). Many drugs qualify for an exclusion, particularly if the expected environmental concentration is below $1 \mathrm{ug} / \mathrm{L}$ (US FDA 1998). Once approved there are no federal water quality criteria or regulations in place to limit the environmental presence of pharmaceuticals and current policies do not evaluate or regulate mixtures of drugs entering the environment.

Alkylphenols are used as surfactants in a variety of household and industrial products, such as cleaners, detergents, soaps, paints, and cosmetics (US EPA 2010). The primary components of these products, alkylphenol ethoxylates, break down rapidly during wastewater treatment and biodegradation in the environment (US EPA 2010). The breakdown products (e.g., nonylphenol and octylphenol) are persistent in the environment and toxic to aquatic life (US EPA 2010). Unlike most PPCPs, water quality criteria exist for nonylphenol (NP). For example, the acute and chronic maximum allowed concentrations for 4-nonylphenol in marine waters is $7 \mathrm{ug} / \mathrm{L}$ and $1.7 \mathrm{ug} / \mathrm{L}$, respectively (US EPA 2010). As a group, alkylphenols act as estrogen mimics and endocrine disruptors and have adverse effects on exposed organisms, including reduced 
growth, increased stress, and altered reproductive activity (Christensen et al. 1999; Ashfield et al. 1998; Granmo et al. 1989).

Several factors influence the concentrations of pharmaceuticals and alkylphenols in the environment, including proximity to wastewater, type of wastewater treatment, population size and product usage patterns, land use, hydrodynamics and residence time, wastewater dilution and mixing, and individual chemical properties (Daughton and Ternes 1999; Gaw et al. 2014; Fabbri and Franzellitti 2016). Since municipal wastewater is a large source of PPCPs, it is expected that concentrations would be highest near wastewater discharges. However, previous studies have shown inconsistent results regarding wastewater proximity as a predictor of pharmaceutical concentration. Dodder et al. (2014) found that pharmaceutical concentrations in mussels collected from 68 marine sites distributed along the entire California coast showed no variation based on land use (urban vs. agricultural) or proximity to municipal discharge. Bayen et al. (2013) had similar results indicating that distance to WWTP did not influence the concentration of pharmaceuticals and endocrine disruptors in seawater from eight sites with different flushing patterns surrounding the island of Singapore. Instead, sites with lowest flushing potential had the highest concentrations, indicating that residence time and hydrodynamics are more important (Bayen et al. 2013). Conversely, Krogh et al. (2017) found that in marine waters off the coast of Victoria, British Columbia, pharmaceutical concentrations in mussel tissues decreased steeply with increasing distance from the nearest WWTP outfall. Similarly, Biel-Maeso et al. (2018) observed pharmaceutical concentrations in estuarine water collected downstream from a WWTP in the Gulf of 
Cadiz, Spain were double the concentration of samples collected further away from the treatment plant, but still within the estuary. With these opposing findings at different geographic locations, questions remain about variation in occurrence of PPCPs at small spatial scales.

The likelihood of a compound to accumulate in organism tissues and sediments can be described using the octanol-water partitioning coefficient $\left(\log \mathrm{K}_{\mathrm{ow}}\right.$ ), or the ratio of the concentration of a compound in octanol and in water. This measures hydrophobicity, with higher values indicating greater potential for accumulation. Although most pharmaceuticals have low $\log \mathrm{K}_{\text {ow }}$ values, they are frequently detected in tissues of marine organisms (e.g., Dodder et al., 2014; Granek et al., 2016; Meador et al., 2016). Alkylphenols are more bioaccumulative than pharmaceuticals and have been detected at concentrations of $66.51-1560.0 \mathrm{ng} / \mathrm{g}$ wet weight in bivalve shellfish (Gu et al. 2016). Therefore, bivalves are a suitable option for measuring local contaminant occurrence for both pharmaceuticals and alkylphenols.

Transplanted bivalves are frequently used to monitor accumulation of contaminants and compare among sites over a specified time period (Hunt and Slone 2010). This allows for better comparison among sites as resident organisms may be more adapted to contaminant stress in their home location than at other sites (Smolders et al. 2003). Pacific oysters are an important commercial bivalve species grown using ground and suspended culture in Oregon and Washington estuaries. Similar to the native Olympia oysters that have been mostly extirpated, Pacific oysters have the potential to provide ecosystem services, such as improving water quality and providing habitat for 
other organisms (Dumbauld et al. 2009; Groth and Rumrill 2009). They are suitable for transplanting because they are sessile filter feeders that can survive a wide range of environmental conditions (Pauley et al. 1988) and their health or condition can be assessed using condition indices (Lucas and Beninger 1985).

Previous work has shown that PPCPs are abundant in highly urbanized estuaries (e.g., (Nilsen et al. 2014; Meador et al. 2016) and in adult native organisms (e.g., Granek et al., 2016) in the Pacific Northwest. However, few studies have examined PPCP presence in organisms transplanted close to wastewater sources and in areas with small human populations. In this study, we examine PPCP accumulation and ecologically relevant effects in Pacific oysters in areas with low human populations. Additionally, we investigate small-scale spatial variation in concentrations and organism health near wastewater treatment plant outfalls using transplanted juvenile oysters collected from a hatchery. Specifically, we address the following research questions:

1. How do transplanted oyster contaminant types and concentrations vary based on proximity to wastewater treatment plant outfalls?

2. Does transplanted oyster health (condition index) vary based on proximity to wastewater treatment plant outfalls?

\subsection{Methods}

\subsubsection{Study Sites}

This study was conducted in three estuaries in Oregon and Washington with significant oyster growing operations and variable pollution inputs: Coos Bay, OR, 
Netarts Bay, OR, and Grays Harbor, WA (Figure 2.1). Sites within these estuaries were classified as either wastewater sites, areas in close proximity to a WWTP outfall (2451500 meters), or oyster growout sites, areas near oyster aquaculture and at least $7 \mathrm{~km}$ from the nearest WWTP outfall. Specific estuary characteristics are reported in Table 2.1.

Table 2.1 Characteristics of study estuaries in OR and WA. Sources: (1) Lee II and Brown 2009, (2) Cortright et al. 1987, (3) US Census Bureau 2019, (4) Souder 2016, (5) Shirzad et al. 1988, (6) Follansbee et al. 1999, (7) WA DOE 2015, (8) Sutherland and O’Neill 2016, (9) Glanzman et al. 1971, (10) Grays Harbor County 2016, (11) NOAA NERRS 2020, (12) Barton et al. 2015.

\begin{tabular}{|c|c|c|c|}
\hline & Coos Bay, OR & Netarts Bay, OR & Grays Harbor, WA \\
\hline $\begin{array}{l}\text { Estuary } \\
\text { Classifications }\end{array}$ & $\begin{array}{l}\text { Tide-dominated; } \\
\text { drowned river } \\
\text { mouth; deep } \\
\text { draft } \\
\text { development }\end{array}$ & $\begin{array}{l}\text { Tide-dominated; } \\
\text { well-mixed; bar built }\end{array}$ & $\begin{array}{l}\text { Tide-dominated; well- } \\
\text { mixed; drowned river mouth }\end{array}$ \\
\hline Area $\left(\mathbf{k m}^{2}\right)$ & 54.9 & 10.43 & 262.7 \\
\hline $\begin{array}{l}\text { Major Freshwater } \\
\text { Input }\end{array}$ & Coos River & Small creeks & Chehalis River \\
\hline Residence Time & $\begin{array}{l}7-16 \text { days (wet } \\
\text { season); } 11-48 \\
\text { days (dry season) }\end{array}$ & $\begin{array}{l}4 \text { days (freshwater } \\
\text { retention time) }\end{array}$ & Not found \\
\hline $\begin{array}{l}\text { Water Temp. } \\
\text { (degrees C) }\end{array}$ & $6-18$ & $9-18$ & $10-18$ \\
\hline Salinity (ppt) & $5-33$ & $25-33$ & $20-33$ \\
\hline pH & $7.7-8.4^{1}$ & $7.6-8.1^{2}$ & $7.4-8.1^{3}$ \\
\hline Major Urban Centers & $\begin{array}{l}\text { Coos Bay, North } \\
\text { Bend }\end{array}$ & Netarts & $\begin{array}{l}\text { Westport, Aberdeen, } \\
\text { Hoquiam, Cosmopolis }\end{array}$ \\
\hline $\begin{array}{l}\text { Approximate } \\
\text { Surrounding } \\
\text { Population }\end{array}$ & 26,180 & 744 & 28,600 \\
\hline Land Uses & $\begin{array}{l}\text { Forest, } \\
\text { residential, } \\
\text { farmland, } \\
\text { industry }\end{array}$ & $\begin{array}{l}\text { Forest, rural } \\
\text { residential }\end{array}$ & Forest, industry, residential \\
\hline \# of WWTPs & 3 & 0 & 4 \\
\hline Sources & $1,2,3,4,8,11$ & $1,5,6,9,12$ & $1,7,10$ \\
\hline
\end{tabular}

${ }^{1}$ Data from summer 2009 at Valino Island station.

${ }^{2}$ Data from summer 2009 monitoring following acidification event in 2008

${ }^{3}$ Data from summer 2009 monitoring in Westport, WA. 


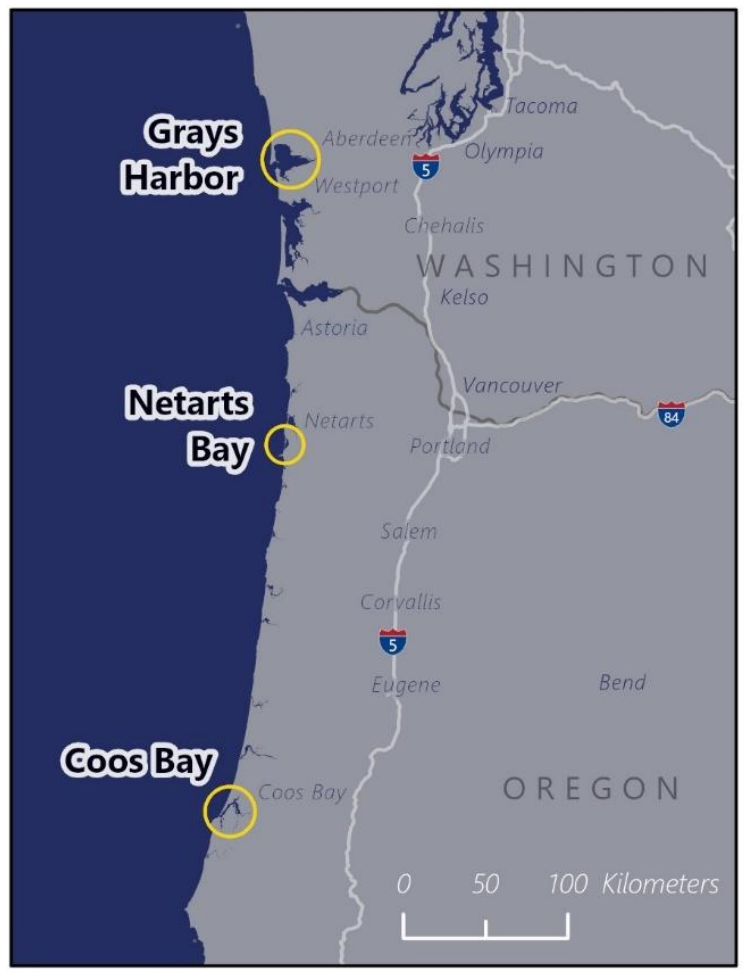

Figure 2.1 Map of estuaries on the OR and WA coast where study sites were set up (indicated by circles and large labels). Cartographic State Boundaries and Highway lines retrieved from Census Tiger Geographic Database; Major Washington cities retrieved from Washington Data Portal; Major Oregon cities retrieved from Oregon Geospatial Data Library in June 2020.

Coos Bay is the largest estuary in Oregon and is located in the Southern coast region. While the surrounding population is small for a city center, it is large compared to other Oregon coast cities and therefore is expected to have moderate PPCP inputs (Table 2.1). Three study sites were chosen within the Coos Estuary: two wastewater sites and one oyster growout site. Sites were chosen based on presence of an outfall, habitat suitability for oysters, and accessibility. There are three WWTPs that discharge into the bay and are located near Empire, North Bend, and the city of Coos Bay. The one closest to the mouth of the bay in Empire is surrounded by sandy habitat, which is not suitable 
for Pacific oysters, which are typically grown on muddy tide flats. The other two treatment plants, in North Bend and the city of Coos Bay, had adjacent accessible mudflat areas so sites were set up near these two plants. Individual treatment plant characteristics are presented in Table 2.2. An area of mudflat to the Southeast of Valino Island near Long Island Point was chosen as an oyster growout site since oyster aquaculture operations were nearby. This area is located in the South Slough National Estuarine Research Reserve and is mainly used for environmental monitoring by the reserve staff. This recreational area with low surrounding population and no direct wastewater inputs has had historical water quality issues, such as shellfish detections of tributyltin (TBT), an antifouling compound used in boat paints (Elgethun et al. 2000) and storm driven increases in bacterial loadings from cattle grazing, failing septic systems, and landfill leachate (Juza 2000) at several sites throughout the slough. While restoration and pollution remediation efforts have improved water quality, it is not considered a pristine area.

Table 2.2 Wastewater treatment plant characteristics at study sites in Coos Bay and North Bend. Discharges are reported in million gallons per day (mgd). Source: (US FDA 2015).

\begin{tabular}{lllll}
\hline Location & $\begin{array}{l}\text { Population } \\
\text { Served }\end{array}$ & $\begin{array}{l}\text { Highest Level of } \\
\text { Treatment }\end{array}$ & $\begin{array}{l}\text { Discharge } \\
\text { Capacity (mgd) }\end{array}$ & $\begin{array}{l}\text { Actual Average } \\
\text { Discharge (mgd) }\end{array}$ \\
\hline North Bend & 9,800 & $\begin{array}{l}\text { Secondary (activated } \\
\text { sludge and chlorine } \\
\text { disinfection) }\end{array}$ & $2.0-5.0$ & 1.0 (dry season); \\
Coos Bay & 11,000 & $\begin{array}{l}\text { Secondary (activated } \\
\text { sludge and chlorine } \\
\text { disinfection) }\end{array}$ & $2.0-5.0$ & 1.6 (dry season); \\
\hline
\end{tabular}

Netarts Bay is a small estuary located on the Northern Oregon coast with low freshwater inputs and high ocean exchange (Lee II and Brown 2009) (Table 2.1). For example, in one tidal cycle, $75 \%$ of the water in the bay is renewed, leaving only $25 \%$ 
residual water at low tide (McCallum 1977). There is no direct municipal or industrial sewage input to Netarts Bay, but septic systems from surrounding homes and a campground south of the bay could be potential sources of wastewater contamination (Glanzman et al. 1971). The closest wastewater treatment plant outfall is located approximately $2 \mathrm{~km}$ north of the mouth of the estuary off the coast of Oceanside, OR. The study site was set up at the south end of Netarts Bay in the Oregon Department of Fish and Wildlife Shellfish Preserve. This site was classified as an oyster growout site due to nearby oyster aquaculture operations and lack of direct wastewater inputs.

Grays Harbor is located on the southern Washington coast and receives $80 \%$ of its freshwater input from the Chehalis River (WA DOE 2015) (Table 2.1). The cities of Westport, Aberdeen, Hoquiam and Cosmopolis comprise the populated areas surrounding Gray's Harbor and have a combined population similar to the Coos Estuary. With the exception of Westport, all of these cities are on the east side of the bay, which is the most heavily populated area and contains heavy industry. Oyster growing takes place mainly in the sparsely populated areas in the north and south, including in Westport which has a lower population than other Grays Harbor cities (WA DOE 2015). There are four wastewater treatment plants with discharges into Gray's Harbor. Two of these are located on the populated east side and two are on the west, just inside the mouth of the estuary. Most of Gray's Harbor is considered uncontaminated, but TMDLs have been developed for fecal coliform, temperature, copper, nutrients, and a dioxin (WA DOE 2015). An oyster growout site was set up in Westport, WA on the property of an oyster grower. The 
closest wastewater treatment plant was approximately $8 \mathrm{~km}$ North along the shoreline towards the mouth of the estuary.

\subsubsection{Oyster Transplantation}

In July 2016, juvenile Pacific oysters ( 1 week old spat) settled on nonliving oyster shells were collected from Whiskey Creek Shellfish Hatchery in Netarts, OR. Oyster shells with spat were placed in mesh growout bags that were tied closed on each end with approximately 20 shells per bag. These juvenile oysters were transplanted to wastewater and oyster growout sites. At each site, three oyster bags were attached with zip ties to PVC racks that elevated the oysters about $1 \mathrm{ft}$ above the mudflat at an approximately $-1.0 \mathrm{ft}$ low tide (Figure 2.2). At the sites with WWTP outfalls, racks were placed along a hypothesized pollution gradient, with one rack as close as possible to the outfall, and remaining racks at increasing distances downstream (Figure 2.2). 


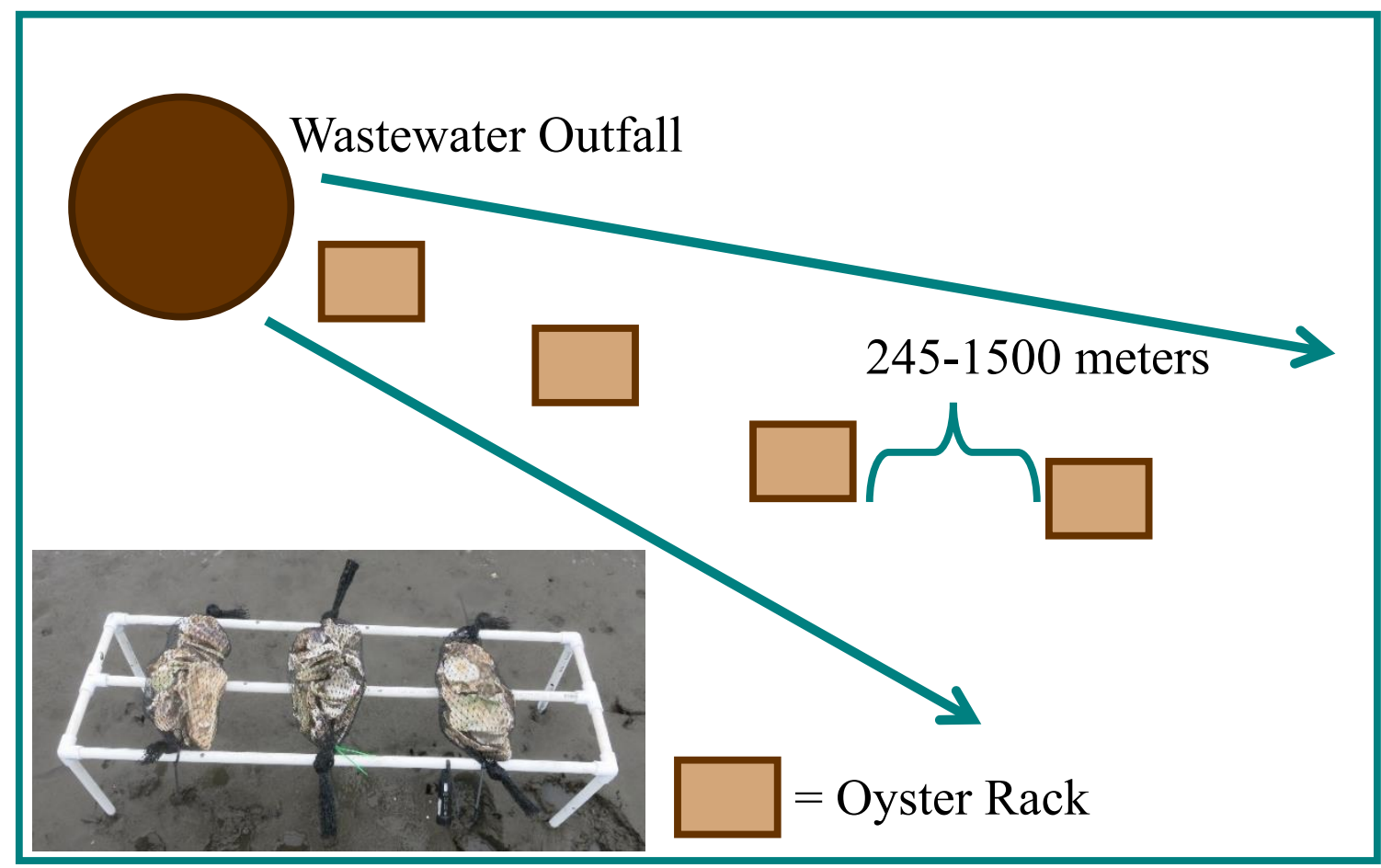

Figure 2.2 Schematic of field design for sites with a wastewater treatment plant outfall and picture of oyster racks with bags of juvenile oysters settled on nonliving oyster shells (inset photo).

The study was designed with the intent of placing four racks per site at a distance of 250 $\mathrm{m}$ apart to examine small-scale spatial variation. The number of racks and distances were adjusted based on accessibility and habitat conditions at each site. In the Coos Bay area, the shoreline is populated with businesses and industry along a single roadway (Tremont Ave) that runs parallel to the shore with no area to pull over. There are limited access points along the road to pull into and park a car. Several sections of the shore are inaccessible to the public due to the road design and business locations. Additionally, the mudflat sediment is very unstable, thus it was not feasible to access sites by walking long distances on the mudflat while carrying equipment. The outfall pipe was located at a 
section of road with no access points and the closest parking area approximately 250 meters upstream of the outfall. The first rack (COOSa) was placed at this site (Figure 2.3). Due to tidal influence and based on a dye study conducted by the Oregon Department of Agriculture in 2011 showing that effluent is reaching this area (US FDA 2015), we assumed that wastewater would reach these oysters upstream of the effluent pipe. The second $(\mathrm{COOSb})$ and third $(\mathrm{COOSc})$ racks were placed at the two closest access points downstream of the outfall, which were 750 and 1,500 meters from the outfall, respectively (Figure 2.3). We were unable to identify a suitable fourth site in this area. In North Bend, racks were placed on a section of mudflat that runs parallel to the airport runway at the Southwest Oregon Regional Airport (Figure 2.3). The WWTP outfall discharges in the middle of the channel to the north of the mudflat. This site was accessed via boat and racks were placed along the mudflat approximately 250 meters apart. Because the outfall was within the channel, the distances from each site to the outfall were $245 \mathrm{~m}(\mathrm{NBc}), 265 \mathrm{~m}(\mathrm{NBb}), 465 \mathrm{~m}(\mathrm{NBa})$, and $480 \mathrm{~m}(\mathrm{NBd})$. The sites closest and furthest from the outfall were on the edge of the accessible mudflat and therefore represent the outer spatial distribution of that area. The aforementioned dye study evaluated discharges from the North Bend outfall and reported dye movement both up- and downstream following discharge, confirming this configuration captures the theoretical plume (US FDA 2015).

At oyster growout sites, racks were placed at distances ranging from 50-250 meters apart to account for environmental variability. Three racks were placed 25 meters apart on a mudflat to the Southeast of Valino Island (VALa, VALb, VALc) (Figure 2.3). 
While there was additional mudflat area available, staff at the South Slough National Estuarine Research Reserve requested that we only use a small space to minimize disturbance of the area due to previous restoration and ongoing monitoring activities. Oyster growing activities were taking place in close proximity to this area on nearby mudflat.

In Netarts Bay, racks were set up at the South end of the bay, in the Oregon Department of Fish and Wildlife designated shellfish preserve. There was ample space and sites were easily accessible so racks were placed 250 meters apart with NETa, NETb, and NETc placed South to North (Figure 2.3). NETa was directly adjacent to an oyster grower. There were originally five sites placed in Netarts, but the two sites north of NETc were missing at the first sampling. In Westport, WA, two racks were placed 25 meters apart on a mudflat on the property of an oyster grower (WESTa, WESTb) (Figure 2.3). The space was very limited so only two racks would fit with a short distance between them. 

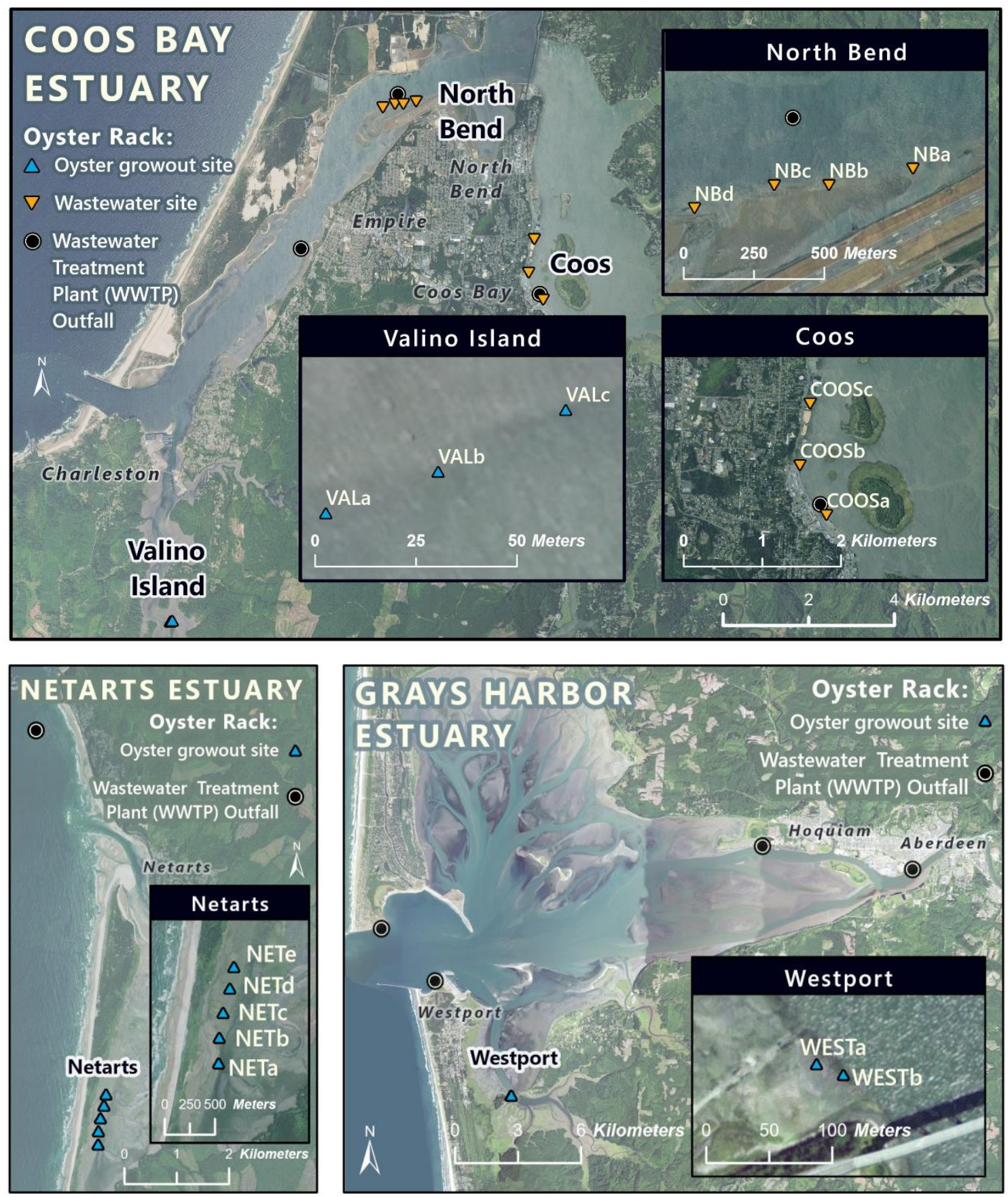

Figure 2.3 Map of study sites and set up of oyster racks at each wastewater and oyster growout site (inset panels): Coos (wastewater site), North Bend (wastewater site), Valino Island (oyster growout site), Netarts (oyster growout site) and Westport, WA (oyster growout site). Imagery provided by National Agricultural Imagery Program (NAIP) under contract for the United States Department of Agriculture (USDA), for the Farm Service Agency’s (FSA) Oregon Imagery Framework Implementation Team. 


\subsubsection{Oyster Measurements}

Oysters were collected from each rack in April 2017 (9-month spring sample) and July 2017 (12-month summer sample). Oysters were brought to the Applied Coastal Ecology lab at Portland State University in bags to be counted and measured. In the April sample, one oyster bag was collected from each rack. At this sampling, oysters were small and tightly clumped together, and it was not possible to separate them without breaking the shells of the oysters. Therefore, oysters were kept in clumps for measurements. Oyster dimensions were recorded based on the methods of (Galtsoff 1964) where the height is described as the distance between the umbo and the top of the shell and the length is the maximum distance across the shell parallel to the hinge. Total abundance was counted, and length and height were measured in millimeters for $50 \%$ of the oysters in the bag. A sample of eight oysters from each rack was shucked and frozen for contaminant analysis.

In the July sample, the remaining two oyster bags from each rack were collected and transported to the lab. The furthest Coos Bay site (COOSc) was missing when July samples were collected, but all others were undisturbed. Oysters were counted and clumps in each bag were broken apart as much as possible. Oyster mass, length, width, and height were measured for $50 \%$ of the oysters, or 100 oysters if the total count was above 200. A sample of ten oysters from each rack was shucked and frozen for contaminant analysis. Samples of 32 oysters per site (16 per bag) were frozen for analysis of condition index (CI), the ratio of dry tissue weight to dry shell weight (Rainer and Mann 1992). This index examines the physiological state of a bivalve with lower values 
indicating stress from unfavorable environmental conditions and is recommended because it is easily standardized and removes bias from moisture content in wet tissue weight measurements (Lucas and Beninger 1985).

Equation 1: $C I=$ dry tissue weight $\times 100 /$ dry shell weight

In summer of 2019, these oysters were thawed, shucked and weighed (tissue weight). Individual oyster tissues were placed in porcelain crucibles and dried for 48-96 hours to constant weight at $105^{\circ} \mathrm{C}$ (Mo and Neilson 1994). Shells were air dried for 24 hours. Dry tissue and shell weights were used to calculate condition index in Microsoft Excel.

\subsubsection{Contaminant Analysis}

In June 2017, ten April samples were sent to AXYS Analytical in British Columbia to be analyzed for 46 pharmaceuticals (Figure D1): all three racks at Coos Bay (WWTP outfall sites), all four racks at North Bend (WWTP outfall sites), and one rack from Valino Island, Netarts Bay, and Westport, WA (oyster growout sites). Funding was inadequate to analyze all racks and therefore we prioritized racks near wastewater to examine small scale spatial variation. July samples were analyzed for a different set of 12 pharmaceuticals (Figure D2), and four alkylphenols at AXYS. The change in analyzed compounds was due to the low detection rate of pharmaceuticals in the April sample and funding constraints. The alkylphenols were broken into two groups: two nonylphenol ethoxylates (NPEs), nonylphenolmonoethoxylate (NP1EO) and nonylphenoldiethoxylate (NP2EO), and two breakdown products, 4-nonylphenol (4-NP) and 4-n-octylphenol (4-n- 
OP). Since we did not see a strong pattern based on proximity to wastewater, one rack per site was chosen for analysis (five samples total) in August 2017.

At AXYS Analytical, pharmaceuticals and alkylphenols were analyzed using liquid chromatography tandem mass spectrometry (LC-MS/MS). Before analysis, pharmaceutical samples were adjusted to a $\mathrm{pH}$ of 2 , spiked with surrogate standards, and extracted by sonication with aqueous buffered and pure acetonitrile. They were then cleaned up using solid phase extraction and analyzed for concentrations using LCMS/MS with electrospray ionization (LC/ESI-MS/MS) in positive ionization mode. Alkylphenol samples were prepared by dispersion in water and addition of labeled surrogate standards and extracted into isooctane by steam distillation. Samples were cleaned up with solid phase extraction and analyzed with LC/ESI-MS/MS in negative ion model for 4-NP and 4-n-OP and positive ion mode for NP1EO and NP2EO. Reporting limits are included in Tables 3 and 4.

\subsubsection{Data Analysis}

Oysters were sampled at different seasons to look at seasonal variation in oyster growth and contaminants, but due to budget constraints and inability to extract whole oysters in the April sample, we were not able to make this comparison. Therefore, April and July sample results were analyzed and summarized separately. The mean and standard deviation were calculated at each rack for oyster height and length in April samples and for all oyster dimensions (height, length, width, and whole oyster mass) in July samples. Due to the variable nature of oyster shape, shell dimensions may yield 
misleading results regarding oyster growth. Instead, condition index was used to compare oyster growth and fitness across racks and sites. Within each site (Coos Bay, North Bend, Valino Island, Netarts, Westport), condition index was compared at each rack, representing distance, using a one-way ANOVA or a two sample T-test with rack and condition index as factors. Tukey’s Honestly Significant Difference post-hoc test was used to determine which racks were different among each site. To compare oyster condition at wastewater (Coos, North Bend) and aquaculture (Valino Island, Netarts, Westport) sites overall, a sample of 50 oysters was randomly selected from all of the racks at each site. With sample sizes ranging from 64 to 128 , this number was chosen to ensure a robust even sample size without sampling more than $80 \%$ of the oysters from a given site. Combining oysters from racks at different distances could potentially violate the independence assumption of parametric statistics. However, due to the substantial distance between sites $(9-400 \mathrm{~km})$ compared to the distance between racks $(25-1500$ meters), we assumed that any differences between racks would be negligible in comparison to differences at an estuary scale. Therefore, we proceeded with a parametric ANOVA. All other assumptions of ANOVA were met (residual normality and equal variance). We ran a post hoc power analysis to determine if this sample size was adequate with the following parameters: effect size calculated as Cohen's f value from the ANOVA output (Ialongo 2016), alpha of 0.05 , and power of 0.80. All analyses were performed in $\mathrm{R}$ version 3.4.1. 


\subsection{Results}

\subsubsection{PPCP Concentrations}

In the April sample, two out of 46 pharmaceuticals were detected in oyster tissues: virginiamycin M1 and miconazole (Table 2.3). Virginiamycin was detected at all wastewater sites, and one oyster growout site (Westport, WA) at an overall range of 1.9$3.83 \mathrm{ng} / \mathrm{g}$ wet weight. The highest concentration $(3.98 \mathrm{ng} / \mathrm{g})$ was at the North Bend rack placed 265 meters from the outfall $(\mathrm{NBb})$ and the lowest concentration was at the Coos Bay rack placed 1,500 meters from the outfall (COOSc). At North Bend, concentrations of virginiamycin at each rack are very similar (difference of less than $1 \mathrm{ng} / \mathrm{g}$ ) but do show slight variation based on distance from the outfall. Concentrations were higher at racks that were in mid-range distances from the outfall, and lowest at the closest and furthest racks, with the furthest rack (NBd, $480 \mathrm{~m}$ ) having the lowest concentration. A similar pattern is evident at the Coos Bay racks with the highest concentration at the middle rack $(\mathrm{COOSb}, 750 \mathrm{~m})$ and the lowest concentration at the furthest rack (COOSc, 1,500 m), but these differences are within $0.50 \mathrm{ng} / \mathrm{g}$ of each other. The concentration at Westport, WA was $2.77 \mathrm{ng} / \mathrm{g}$, intermediate between the concentrations at Coos Bay and North Bend. Miconazole was only detected in oysters at the Coos Bay site at concentrations of 0.87 and $0.63 \mathrm{ng} / \mathrm{g}$ at racks $250(\mathrm{COOSa})$ and 1,500 (COOSc) meters from the outfall, respectively. The concentration was higher closer to the outfall, but it is important to note that these concentrations are very low and close to the detection limit.

Table 2.3 Concentrations of pharmaceuticals detected in April 2017 oyster tissues at wastewater sites (Coos, North Bend) and oyster growout sites (Westport, Netarts, Valino Island) reported in nanograms/gram (ng/g) wet weight. Distance from the nearest wastewater treatment plant outfall is listed in meters $(\mathrm{m})$ for each oyster rack at the 
wastewater sites. For the oyster growout sites, there were no WWTPs in close proximity. The shoreline distance to the nearest outfall was 7,500 meters or greater at each oyster growout site. Westport, WA has two upstream wastewater treatment plants $>18 \mathrm{~km}$ away. Each sample is a composite of 8 oysters. ${ }^{\wedge}$ denotes concentration less than $2 \mathrm{x}$ lab blank or reporting limit. $\mathrm{ND}=$ not detected $\mathrm{RL}=$ reporting limit.

\begin{tabular}{|c|c|c|c|c|c|}
\hline Site & Rack & Site Type & $\begin{array}{l}\text { Distance to } \\
\text { nearest WWTP } \\
\text { Outfall }\end{array}$ & $\begin{array}{l}\text { Virginiamycin } \\
\text { M1 (RL) }\end{array}$ & $\begin{array}{l}\text { Miconazole } \\
\text { (RL) }\end{array}$ \\
\hline Coos Bay & COOSa & Wastewater & $250 \mathrm{~m}$ & $2.22^{\wedge}(1.20)$ & $0.87^{\wedge}(0.60)$ \\
\hline Coos Bay & COOSb & Wastewater & $750 \mathrm{~m}$ & $2.38^{\wedge}(1.21)$ & ND \\
\hline Coos Bay & COOSc & Wastewater & $1,500 \mathrm{~m}$ & $1.9^{\wedge}(1.24)$ & $0.63^{\wedge}(.59)$ \\
\hline North Bend & $\mathrm{NBc}$ & Wastewater & $245 \mathrm{~m}$ & $3.83(1.21)$ & ND \\
\hline North Bend & $\mathrm{NBb}$ & Wastewater & $265 \mathrm{~m}$ & $3.98(1.21)$ & ND \\
\hline North Bend & $\mathrm{Nba}$ & Wastewater & $465 \mathrm{~m}$ & $3.84(1.20)$ & ND \\
\hline North Bend & $\mathrm{NBd}$ & Wastewater & $480 \mathrm{~m}$ & $3.28(1.20)$ & ND \\
\hline Valino Island & VALa & $\begin{array}{l}\text { Oyster } \\
\text { Growout }\end{array}$ & N/A & ND & ND \\
\hline Netarts Bay & NETc & $\begin{array}{l}\text { Oyster } \\
\text { Growout }\end{array}$ & N/A & ND & ND \\
\hline Westport & WESTa & $\begin{array}{l}\text { Oyster } \\
\text { Growout }\end{array}$ & N/A & $2.77(1.22)$ & ND \\
\hline
\end{tabular}

All four alkylphenols were detected in oyster tissues in July 2017 (Table 2.4), but none of the 12 pharmaceuticals were present. NP1EO was detected at Coos Bay and Westport at concentrations of 4.24 and $15.4 \mathrm{ng} / \mathrm{g}$, respectively. NP2EO was detected at all sites, at a range of 0.61-1.92 ng/g, with the highest concentration at Westport, WA. Nonylphenol (4-NP) was detected at all sites, and had the highest overall concentration compared to other alkylphenols ranging from 12.2-43.8 ng/g, with the highest concentration at Westport, WA. Octylphenol (4n-OP) was found at all sites except for Netarts, at a range of 1.61-3.94 ng/g, with the highest concentration at Valino Island. Overall, alkylphenols were widespread throughout the sites, regardless of distance to wastewater, except Netarts Bay which had fewer detections and lower concentrations (Table 2.4). 
Table 2.4 Concentration of alkylphenols detected in July 2017 oyster tissues at all sites sampled: wastewater (Coos, North Bend) and oyster growout (Westport, Netarts, Valino Island) reported in nanograms/gram (ng/g) wet weight. Distance from the nearest wastewater treatment plant outfall is listed in meters $(\mathrm{m})$ for each oyster rack. Each sample is a composite of 10 oysters. ${ }^{\wedge}$ denotes concentration less than $2 \mathrm{x}$ lab blank or reporting limit. $\mathrm{ND}=$ not detected. $\mathrm{RL}=$ reporting limit.

\begin{tabular}{|c|c|c|c|c|c|c|c|}
\hline Site & Rack & Site Type & $\begin{array}{l}\text { Distance to } \\
\text { WWTP } \\
\text { Outfall }\end{array}$ & $\begin{array}{l}\text { NP1EO } \\
\text { (RL) }\end{array}$ & $\begin{array}{l}\text { NP2EO } \\
\text { (RL) }\end{array}$ & $\begin{array}{l}\text { 4-NP } \\
\text { (RL) }\end{array}$ & $\begin{array}{l}\text { 4n-OP } \\
\text { (RL) }\end{array}$ \\
\hline Coos Bay & COOSa & Wastewater & $250 \mathrm{~m}$ & $\begin{array}{l}4.24 \\
(1.87)\end{array}$ & $\begin{array}{l}1.47 \\
(0.47)\end{array}$ & $\begin{array}{l}15.9 \\
(0.76)\end{array}$ & $\begin{array}{l}1.61 \\
(0.52)\end{array}$ \\
\hline North Bend & $\mathrm{NBb}$ & Wastewater & $265 \mathrm{~m}$ & ND & $\begin{array}{l}1.35 \\
(0.48)\end{array}$ & $\begin{array}{l}14.7 \\
(0.48)\end{array}$ & $\begin{array}{l}2.38 \\
(0.61)\end{array}$ \\
\hline $\begin{array}{l}\text { Valino } \\
\text { Island }\end{array}$ & VALc & Oyster Growout & $10,000 \mathrm{~m}$ & ND & $\begin{array}{l}1.15 \\
(0.47)\end{array}$ & $\begin{array}{l}14.4 \\
(.67)\end{array}$ & $\begin{array}{l}3.94 \\
(0.98)\end{array}$ \\
\hline Netarts Bay & NETc & Oyster Growout & $8,900 \mathrm{~m}$ & ND & $\begin{array}{l}0.61^{\wedge} \\
(0.50)\end{array}$ & $\begin{array}{l}12.2 \\
(0.71)\end{array}$ & ND \\
\hline Westport & WESTa & Oyster Growout & $8,110 \mathrm{~m}$ & $\begin{array}{l}15.4 \\
(1.0)\end{array}$ & $\begin{array}{l}1.92 \\
(.47)\end{array}$ & $\begin{array}{l}43.8 \\
(0.53)\end{array}$ & $\begin{array}{l}1.95 \\
(0.52)\end{array}$ \\
\hline
\end{tabular}

\subsubsection{Oyster Size and Condition}

Oyster size was highly variable among sites and racks. The mean (and standard deviation) of shell height for oysters at all sites was 35.24 (11.26) mm among April samples (Table A1) and 44.54 (13.38) among July samples, and the mean whole oyster weight was 11.98 (7.33) g among July samples (Table A2). The number of oysters per bag ranged from 55-402 in April samples and 47-578 in July samples. In April, oysters at Valino Island were larger, but this pattern was not evident in July. A summary of oyster dimensions and abundance for each rack, as well as fouling organisms within oyster bags, is provided in the Appendix (Table A1, A2, and A3).

Oyster condition index was relatively similar across four sites (Coos Bay, North Bend, Netarts Bay, Westport), but significantly higher at Valino Island (Table 2.5, Figure 
2.4A)(One-Way ANOVA: $\left.\mathrm{p}<.001, \mathrm{~F}_{4,245}=28.017\right)$. The power analysis showed that a sample size of six oysters would be adequate, therefore we conclude that our sample size of 50 per site here was enough to detect significant differences among sites. When comparing rack distance at individual sites, differences in oyster condition were only observed at oyster growout sites with racks spaced along an environmental gradient (Table 2.6, Figure 2.4). At wastewater sites, mean condition index did not differ between racks placed at varying distances from a wastewater outfall (Coos Bay: two sample t-test: $\mathrm{p}=.68, \mathrm{t}_{61}=.41$, Figure 2.4B; North Bend: one-way ANOVA: $\mathrm{p}=.26, \mathrm{~F}_{3,123}=1.35$, Figure 2.4C). At Valino Island, condition index at the most downstream site, VALa, was significantly higher than VALb, but not VALc, the upstream site (one-way ANOVA: $\mathrm{p}=.02, \mathrm{~F}_{2,93}=3.91$, Figure 2.4D). At Netarts Bay, the most downstream site, NETc had significantly lower condition index than the other two upstream Netarts Bay racks (NETa and NETb) (one-way ANOVA: $\mathrm{p}<.001, \mathrm{~F}_{2,93}=19.84$, Figure 2.4D). At Westport, condition index was similar between both racks, WESTa and WESTb (two sample t-test: $\mathrm{p}=.17, \mathrm{~T}_{62}=1.38$, Figure $\left.2.4 \mathrm{~F}\right)$.

Table 2.5 Summary of condition index and oyster dimensions for 50 randomly selected oysters from all racks within each site. Avg = average, $\mathrm{SD}=$ standard deviation, $\mathrm{g}=$ grams, $\mathrm{mm}=$ millimeters.

\begin{tabular}{llllll}
\hline & $\begin{array}{l}\text { Avg Condition } \\
\text { Index (SD) }\end{array}$ & $\begin{array}{l}\text { Avg Wet } \\
\text { Tissue Weight } \\
\text { (g) (SD) }\end{array}$ & $\begin{array}{l}\text { Avg Shell } \\
\text { Height }(\mathbf{m m}) \\
\text { (SD) }\end{array}$ & $\begin{array}{l}\text { Avg Shell } \\
\text { Length (mm) } \\
\text { (SD) }\end{array}$ & $\begin{array}{l}\text { Avg Shell } \\
\text { Width (mm) } \\
\text { (SD) }\end{array}$ \\
\hline Coos Bay & $6.71(1.71)$ & $3.42(1.47)$ & $52.82(10.83)$ & $36.64(7.1)$ & $14.37(4)$ \\
North Bend & $6.27(2.1)$ & $2.14(1.66)$ & $45.77(10.28)$ & $32.26(9.54)$ & $11.74(2.73)$ \\
Valino Island & $10.63(2.66)$ & $5.19(1.97)$ & $56.66(10.07)$ & $36.84(8.69)$ & $15.03(3.94)$ \\
Netarts Bay & $7.34(2.36)$ & $3.33(1.62)$ & $50.07(10.41)$ & $34.39(5.97)$ & $13.05(3.54)$ \\
Westport & $7.34(2.57)$ & $3.3(1.66)$ & $51.16(11.98)$ & $34.97(10.05)$ & $12.4(3.42)$ \\
\hline
\end{tabular}


Table 2.6 Summary of condition index and oyster dimensions for one-year transplanted Pacific oysters collected in July 2017. Samples of 32 oysters were randomly chosen from each rack; $\mathrm{Avg}=$ average, $\mathrm{SD}=$ standard devation, $\mathrm{g}=$ grams, $\mathrm{mm}=$ millimeters.

\begin{tabular}{|c|c|c|c|c|c|c|c|}
\hline Site & Rack & $\begin{array}{l}\text { Distance } \\
\text { to } \\
\text { WWTP } \\
\text { Outfall } \\
\text { (m) }\end{array}$ & $\begin{array}{l}\text { Avg } \\
\text { Condition } \\
\text { Index } \\
\text { (SD) } \\
\end{array}$ & $\begin{array}{l}\text { Avg Wet } \\
\text { Tissue } \\
\text { Weight } \\
\text { (g) (SD) } \\
\end{array}$ & $\begin{array}{l}\text { Avg Shell } \\
\text { Height } \\
(\mathbf{m m})(\mathrm{SD})\end{array}$ & $\begin{array}{l}\text { Avg Shell } \\
\text { Length } \\
(\mathrm{mm})(\mathrm{SD})\end{array}$ & $\begin{array}{l}\text { Avg Shell } \\
\text { Width } \\
\text { (mm) } \\
\text { (SD) }\end{array}$ \\
\hline Coos Bay & COOSa & 250 & $\begin{array}{l}6.98 \\
(1.64)\end{array}$ & $\begin{array}{l}3.31 \\
(1.52)\end{array}$ & $\begin{array}{l}51.98 \\
(12.75)\end{array}$ & $\begin{array}{l}36.42 \\
(6.65)\end{array}$ & $\begin{array}{l}13.98 \\
(4.25)\end{array}$ \\
\hline Coos Bay & COOSb & 750 & $\begin{array}{l}6.79 \\
(1.82)\end{array}$ & $\begin{array}{l}3.50 \\
(1.25)\end{array}$ & $\begin{array}{l}53.54 \\
(7.79)\end{array}$ & $\begin{array}{l}36.64 \\
(6.88)\end{array}$ & $\begin{array}{l}14.73 \\
(3.29)\end{array}$ \\
\hline North Bend & $\mathrm{NBc}$ & 245 & $\begin{array}{l}7.00 \\
(2.60)\end{array}$ & $\begin{array}{l}2.47 \\
(2.10)\end{array}$ & $\begin{array}{l}41.17 \\
(13.15)\end{array}$ & $\begin{array}{l}36.37 \\
(13.05)\end{array}$ & $\begin{array}{l}12.21 \\
(2.64)\end{array}$ \\
\hline North Bend & $\mathrm{NBb}$ & 265 & $\begin{array}{l}5.83 \\
(2.76)\end{array}$ & $\begin{array}{l}1.43 \\
(0.75)\end{array}$ & $\begin{array}{l}40.12 \\
(10.32)\end{array}$ & $\begin{array}{l}32.14 \\
(8.92)\end{array}$ & $\begin{array}{l}11.93 \\
(2.76)\end{array}$ \\
\hline North Bend & $\mathrm{Nba}$ & 465 & $\begin{array}{l}6.06 \\
(2.62)\end{array}$ & $\begin{array}{l}2.11 \\
(1.43)\end{array}$ & $\begin{array}{l}45.39 \\
(10.98)\end{array}$ & $\begin{array}{l}32.64 \\
(9.18)\end{array}$ & $\begin{array}{l}12.39 \\
(3.33)\end{array}$ \\
\hline North Bend & NBd & 480 & $\begin{array}{l}6.11 \\
(1.87)\end{array}$ & $\begin{array}{l}2.35 \\
(1.70)\end{array}$ & $\begin{array}{l}48.74 \\
(9.96)\end{array}$ & $\begin{array}{l}34.32 \\
(7.76)\end{array}$ & $\begin{array}{l}11.08 \\
(2.44)\end{array}$ \\
\hline Valino Island & VALa & N/A & $\begin{array}{l}11.30 \\
(2.69)\end{array}$ & $\begin{array}{l}5.63 \\
(2.41)\end{array}$ & $\begin{array}{l}57.56 \\
(8.82)\end{array}$ & $\begin{array}{l}38.02 \\
(8.13)\end{array}$ & $\begin{array}{l}14.24 \\
(3.63)\end{array}$ \\
\hline Valino Island & VALb & N/A & $\begin{array}{l}9.17 \\
(2.92)\end{array}$ & $\begin{array}{l}4.54 \\
(2.85)\end{array}$ & $\begin{array}{l}56.78 \\
(12.24)\end{array}$ & $\begin{array}{l}36.64 \\
(9.90)\end{array}$ & $\begin{array}{l}13.54 \\
(3.75)\end{array}$ \\
\hline Valino Island & VALc & N/A & $\begin{array}{l}10.30 \\
(3.43)\end{array}$ & $\begin{array}{l}5.05 \\
(1.86)\end{array}$ & $\begin{array}{l}58.80 \\
(12.70)\end{array}$ & $\begin{array}{l}37.08 \\
(8.25)\end{array}$ & $\begin{array}{l}14.23 \\
(3.80)\end{array}$ \\
\hline Netarts Bay & NETa & N/A & $\begin{array}{l}7.32 \\
(2.41)\end{array}$ & $\begin{array}{l}2.93 \\
(1.53)\end{array}$ & $\begin{array}{l}50.27 \\
(6.89)\end{array}$ & $\begin{array}{l}33.34 \\
(5.58)\end{array}$ & $\begin{array}{l}12.52 \\
(3.63)\end{array}$ \\
\hline Netarts Bay & NETb & N/A & $\begin{array}{l}8.39 \\
(2.21)\end{array}$ & $\begin{array}{l}4.10 \\
(1.72)\end{array}$ & $\begin{array}{l}51.86 \\
(10.10)\end{array}$ & $\begin{array}{l}33.67 \\
(6.31)\end{array}$ & $\begin{array}{l}15.09 \\
(4.35)\end{array}$ \\
\hline Netarts Bay & NETc & N/A & $\begin{array}{l}5.14 \\
(1.63)\end{array}$ & $\begin{array}{l}2.21 \\
(1.11)\end{array}$ & $\begin{array}{l}45.99 \\
(11.36)\end{array}$ & $\begin{array}{l}33.21 \\
(6.26)\end{array}$ & $\begin{array}{l}11.66 \\
(2.65)\end{array}$ \\
\hline Westport & WESTa & N/A & $\begin{array}{l}7.54 \\
(2.35)\end{array}$ & $\begin{array}{l}3.18 \\
(1.45)\end{array}$ & $\begin{array}{l}49.96 \\
(14.71)\end{array}$ & $\begin{array}{l}37.15 \\
(10.02)\end{array}$ & $\begin{array}{l}12.75 \\
(3.37)\end{array}$ \\
\hline Westport & WESTb & N/A & $\begin{array}{l}6.70 \\
(2.49)\end{array}$ & $\begin{array}{l}3.30 \\
(1.54)\end{array}$ & $\begin{array}{l}53.38 \\
(9.21)\end{array}$ & $\begin{array}{l}32.58 \\
(8.99)\end{array}$ & $\begin{array}{l}11.88 \\
(2.91)\end{array}$ \\
\hline
\end{tabular}



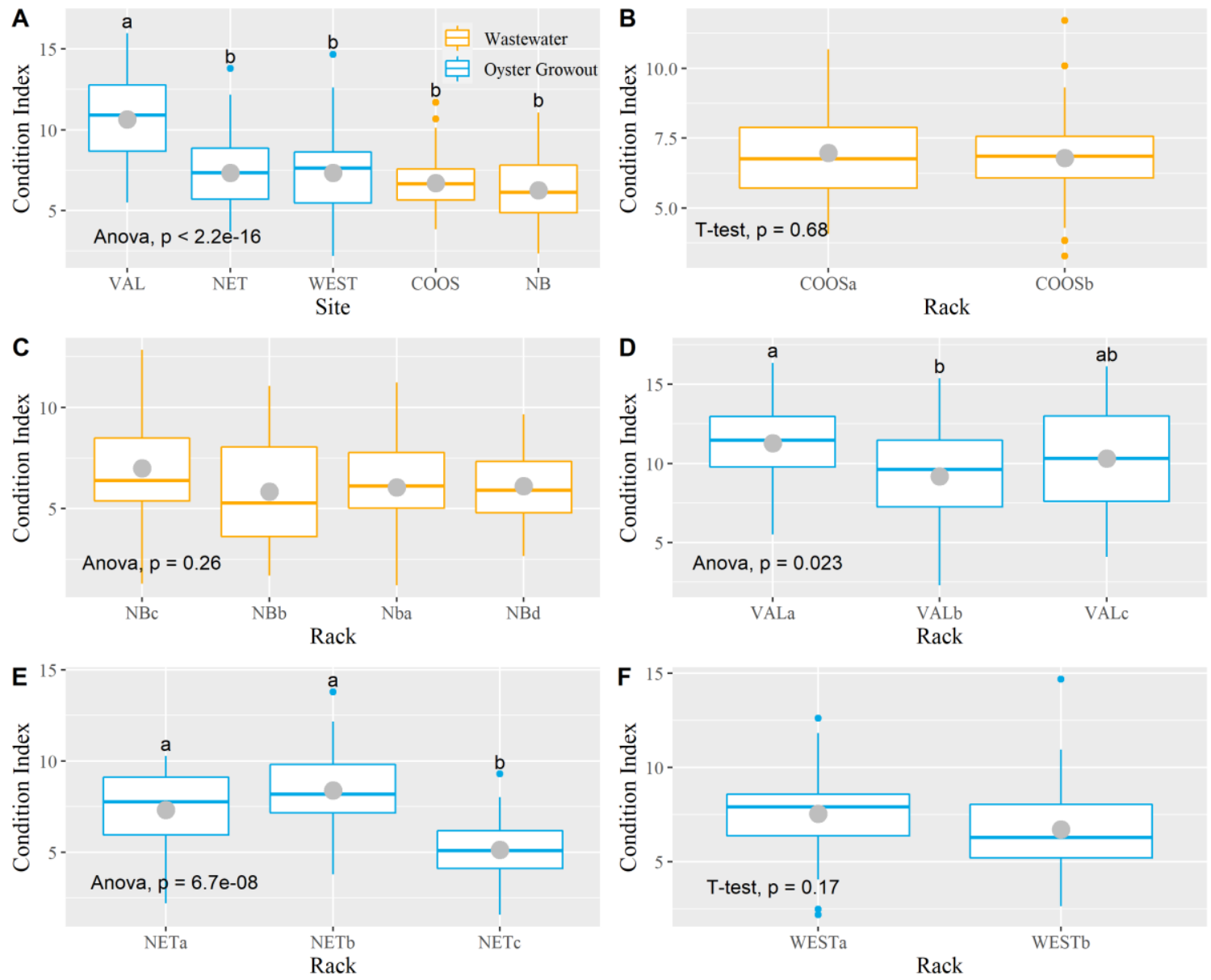

Figure 2.4 Condition index of one-year transplanted Pacific oysters collected in July 2017 compared at all sites (A), and at racks within each site for Coos Bay (B), North Bend (C), Valino Island (D), Netarts Bay (E), and Westport, WA (F). Coos Bay and North Bend are wastewater sites and racks are listed based on proximity to wastewater from left to right. P-values and letters above bars based on results of one-way ANOVA and two-sample ttests comparing condition index at each site and rack. Gray dots represent the mean for each group.

\subsection{Discussion}

Pharmaceuticals were detected in oyster tissues in OR and WA at the two wastewater sites, Coos Bay and North Bend, and one oyster growout site, Westport. Virginiamycin and miconazole were the only pharmaceuticals found out of the 58 examined in this study, indicating that risk of exposure could be lower in low population 
areas. Virginiamycin is an antibiotic used to reduce microbial contamination in ethanol production (Hynes et al. 1997) and as a growth promoter in livestock farming in the United States (Dumonceaux et al. 2006; Dzhavakhiya et al. 2016). Miconazole is a human over the counter drug for treating fungal infections such as athlete's foot (e.g., Lotrimin powder). The concentrations reported in this study are low for virginiamycin and within a comparable range for miconazole relative to other reported concentrations in marine animal tissues (Table 2.7). For example, higher concentrations of virginiamycin were detected in fish in Puget Sound, WA (Meador et al. 2016) and Atlantic salmon advertised as "antibiotic free" in the southwestern US (Done and Halden 2015), and similar concentration were found in oysters in Netarts Bay, Oregon (Granek et al. 2016).

Four alkylphenols targeted in this study (4-NP, 4-n-OP, NP1E0, and NP2EO) were detected in oyster tissues with at least one compound detected at every site. These compounds have been detected in marine animal tissues in several other studies (e.g., Maruya et al., 2012; Klosterhaus et al., 2013; Dodder et al., 2014; Gu et al., 2016; Granek et al., 2016; Meador et al., 2016). The concentrations reported in this study are similar to detections in marine animal tissue the Pacific Northwest (Granek et al. 2016; Meador et al. 2016), slightly lower than urban areas of the U.S. west coast (Maruya et al. 2012; Klosterhaus et al. 2013), and notably lower than those reported in a heavily populated area in China (Gu et al. 2016) (Table 2.7). For NP1EO and NP2EO, our concentrations are similar to the low ranges reported in Puget Sound fish tissues (Meador et al. 2016), but were approximately 2-12 ng/g higher for NP1EO and 1 ng/g higher for NP2EO than Olympia Oysters in Netarts Bay and Coos Bay (Granek et al. 2016). For nonylphenol (4- 
NP), concentrations were relatively similar to Pacific Northwest studies, but the Westport site concentration was higher than in both Netarts and Coos Bay in Granek et al. (2016). Concentrations of 4-NP were lower than some reports in flatfish in Southern California (Maruya et al. 2012) and mussels in the San Francisco Bay (Klosterhaus et al. 2013). One study in China detected much higher concentrations of 4-nonylphenol in marine mollusks (Gu et al. 2016). Only one other study (Granek et al. 2016) reported concentrations of 4$\mathrm{n}-\mathrm{OP}$ in marine animal tissues and the concentrations were similar to those in this study.

Table 2.7 Concentrations of pharmaceuticals and alklyphenols in marine organism tissues reported in recent literature in nanograms per gram on a wet weight basis ( $\mathrm{ng} / \mathrm{g} \mathrm{ww})$. Ehrhart and Granek 2020 refers to this study.

\begin{tabular}{lllll}
\hline Compound & $\begin{array}{l}\text { Concentration } \\
\text { (ng/g ww) }\end{array}$ & Organism & Location & Source \\
\hline Virginiamycin & $1.9-3.98$ & $\begin{array}{l}\text { Pacific oyster } \\
\text { (Crassostrea gigas) }\end{array}$ & $\begin{array}{l}\text { Coos Bay, OR; } \\
\text { Grays Harbor, } \\
\text { WA }\end{array}$ & $\begin{array}{l}\text { Ehrhart and Granek } \\
(2020)\end{array}$ \\
& $8-34$ & $\begin{array}{l}\text { Pacific staghorn } \\
\text { sculpin (Leptocottus } \\
\text { armatus) }\end{array}$ & $\begin{array}{l}\text { Puget Sound, } \\
\text { WA }\end{array}$ & Meador et al. (2016) \\
& 5.2 & $\begin{array}{l}\text { Atlantic salmon } \\
\text { (Salmo salar) }\end{array}$ & $\begin{array}{l}\text { Farmed seafood } \\
\text { purchased in US } \\
\text { originating from }\end{array}$ & (Done and Halden \\
Scotland
\end{tabular}




\begin{tabular}{|c|c|c|c|c|}
\hline & 41.2 & $\begin{array}{l}\text { Ribbed horsemussel } \\
-(\text { Geukensia } \\
\text { demissa })\end{array}$ & $\begin{array}{l}\text { San Francisco } \\
\text { Bay, CA }\end{array}$ & $\begin{array}{l}\text { Klosterhaus et al. } \\
\text { (2013) }\end{array}$ \\
\hline \multirow[t]{6}{*}{ NP2EO } & $0.61-1.92$ & $\begin{array}{l}\text { Pacific oyster } \\
\text { (Crassostrea gigas) }\end{array}$ & $\begin{array}{l}\text { Coos Bay, OR; } \\
\text { Netarts Bay, OR; } \\
\text { Grays Harbor, } \\
\text { WA }\end{array}$ & $\begin{array}{l}\text { Ehrhart and Granek } \\
(2020)\end{array}$ \\
\hline & $1.4-51$ & $\begin{array}{l}\text { Chinook salmon } \\
\text { (Oncorhynchus } \\
\text { tshawytscha) }\end{array}$ & $\begin{array}{l}\text { Puget Sound, } \\
\text { WA }\end{array}$ & Meador et al. (2016) \\
\hline & $1.9-17$ & $\begin{array}{l}\text { Pacific staghorn } \\
\text { sculpin (Leptocottus } \\
\text { armatus) }\end{array}$ & $\begin{array}{l}\text { Puget Sound, } \\
\text { WA }\end{array}$ & Meador et al. (2016) \\
\hline & $0.533-0.879$ & $\begin{array}{l}\text { Olympia oysters } \\
\text { (Ostrea lurida) }\end{array}$ & Netarts Bay, OR & Granek et al. (2016) \\
\hline & $0.861-0.935$ & $\begin{array}{l}\text { Olympia oysters } \\
\text { (Ostrea lurida) }\end{array}$ & Coos Bay, OR & Granek et al. (2016) \\
\hline & 192 & $\begin{array}{l}\text { Ribbed horsemussel } \\
-(\text { Geukensia } \\
\text { demissa })\end{array}$ & $\begin{array}{l}\text { San Francisco } \\
\text { Bay, CA }\end{array}$ & $\begin{array}{l}\text { Klosterhaus et al. } \\
\text { (2013) }\end{array}$ \\
\hline \multirow[t]{8}{*}{ 4-NP } & $12.2-43.8$ & $\begin{array}{l}\text { Pacific oyster } \\
\text { (Crassostrea gigas) }\end{array}$ & $\begin{array}{l}\text { Coos Bay, OR; } \\
\text { Netarts Bay, OR; } \\
\text { Grays Harbor, } \\
\text { WA }\end{array}$ & $\begin{array}{l}\text { Ehrhart and Granek } \\
(2020)\end{array}$ \\
\hline & $30-76$ & $\begin{array}{l}\text { Chinook salmon } \\
\text { (Oncorhynchus } \\
\text { tshawytscha) }\end{array}$ & $\begin{array}{l}\text { Puget Sound, } \\
\text { WA }\end{array}$ & Meador et al. (2016) \\
\hline & $7.7-35$ & $\begin{array}{l}\text { Pacific staghorn } \\
\text { sculpin (Leptocottus } \\
\text { armatus) }\end{array}$ & $\begin{array}{l}\text { Puget Sound, } \\
\text { WA }\end{array}$ & Meador et al. (2016) \\
\hline & 31.6 & $\begin{array}{l}\text { Olympia oysters } \\
\text { (Ostrea lurida) }\end{array}$ & Netarts Bay, OR & Granek et al. (2016) \\
\hline & $19.5-20.0$ & $\begin{array}{l}\text { Olympia oysters } \\
\text { (Ostrea lurida) }\end{array}$ & Coos Bay, OR & Granek et al. (2016) \\
\hline & $25-290$ & $\begin{array}{l}\text { Hornyhead turbot } \\
\text { (Pleuronichthys } \\
\text { verticalis) }\end{array}$ & Southern CA & (Maruya et al. 2012) \\
\hline & 94.5 & $\begin{array}{l}\text { Ribbed horsemussel } \\
-(\text { Geukensia } \\
\text { demissa })\end{array}$ & $\begin{array}{l}\text { San Francisco } \\
\text { Bay, CA }\end{array}$ & $\begin{array}{l}\text { Klosterhaus et al. } \\
(2013)\end{array}$ \\
\hline & $66.51-1560.0$ & $\begin{array}{l}\text { Marine molluscs } \\
\text { (Bullacta exarata, } \\
\text { Cyclinas inensis, } \\
\text { Sinonovacula sp.) }\end{array}$ & $\begin{array}{l}\text { Yangtze River } \\
\text { Delta, China }\end{array}$ & (Gu et al. 2016) \\
\hline 4-n-OP & $1.61-3.94$ & $\begin{array}{l}\text { Pacific oyster } \\
\text { (Crassostrea gigas) }\end{array}$ & $\begin{array}{l}\text { Coos Bay, OR; } \\
\text { Grays Harbor, } \\
\text { WA }\end{array}$ & $\begin{array}{l}\text { Ehrhart and Granek } \\
(2020)\end{array}$ \\
\hline
\end{tabular}


Pharmaceutical occurrence was more frequent at wastewater sites with Westport, WA being the only oyster growout site with detections. However, there was little variation in pharmaceutical concentration within these sites based on proximity to wastewater outfalls. Though racks were spaced to examine small scale variation in concentration, no prominent pattern was observed among racks within the site pollution gradient for Coos Bay and North Bend. Concentrations across racks were very similar and close to the detection limit. Trends in concentrations and detections, or lack thereof, could be due to various factors, including local hydrodynamics and individual chemical properties. A study in Coos Bay evaluated hydrodynamics of effluent plumes in the winter from both WWTPs by tracking dye released from the treatment plants over 12-19 hours (US FDA 2015). Results from this study show that under high flow conditions, the effluent plume in North Bend would travel across our entire study area in approximately $30 \mathrm{~min}$. Therefore, effluent exposure can be considered ubiquitous around the racks which could explain the lack of variability in virginiamycin concentration in North Bend. A similar pattern was observed for Coos Bay. The dye study also found that dilution did not increase linearly with distance from the outfalls, which could explain the slightly higher concentration of virginiamycin at the COOSb rack that was in the middle of the closest and furthest racks from the outfall. Miconazole and virginiamycin have log $\mathrm{K}_{\mathrm{ow}}$ coefficients of 6.1 and 1.52 , respectively, indicating that miconazole would be more likely to accumulate than virginiamycin. Yet we found virginiamycin at more sites and at 
higher concentrations, emphasizing that $\log \mathrm{K}_{\mathrm{ow}}$ is only one of many factors that affect bioaccumulation.

Virginiamycin was detected at an oyster growout site (Westport, WA), despite the increased distance from wastewater influences. To our knowledge, no ethanol production takes place in Grays Harbor and livestock rearing operations were not identified in close proximity to the site. The closest farms are upstream along the Chehalis River, which are likely too far away to be the major source of this compound in Westport. The surrounding area is mainly residential. Several studies have identified traces of virginiamycin and other antibiotics in a byproduct of fuel ethanol production called distiller grains, which are commonly used in animal feeds, including pet food (Olendorff et al. in press, Bischoff et al. 2016, Compart et al. 2013). Therefore, farm and household animal feeding could constitute a more widespread source of this antibiotic. Additionally, ethanol is added to all gasoline in OR and WA and if traces of antibiotics are present in the final ethanol product, surface runoff and boat motors could be other potential sources. However, only one study tested ethanol for virginiamycin and it was not detected (Hamdy et al. 1996). This study was conducted prior to analytical advances that would allow for detections at the ng/L and ug/L level and therefore could underestimate presence in ethanol. More research is needed to identify antibiotics in ethanol given the widespread use in ethanol production, presence in byproducts, and environmental occurrence.

Other studies have identified virginiamycin detections in animal tissues without a known or suspected source. In two recent studies, virginiamycin was found in marine 
animals in close proximity to a wastewater outfall, but was not detected in the effluent or surrounding water (Meador et al. 2016; Krogh et al. 2017). Krogh et al. (2017) found an increase in virginiamycin concentrations in marine mussels with distance to a wastewater outfall and reported concentrations of $67.4,70.1$, and $87.1 \mathrm{ng} / \mathrm{g}$ dry weight next to the outfall, $200 \mathrm{~m}$ from the outfall, and at a reference site greater than $5000 \mathrm{~m}$ from the outfall, respectively (Krogh et al. 2017). Similarly, James et al. (2020) found virginiamycin in mussels at a reference site in Puget Sound and suggest that it may be from a naturally occurring source, such as bacteria in marine sediments. Bacterial isolates with gene sequences closely related to Streptomyces virginiae, the bacteria that produces virginiamycin, have been identified in marine sediments in the Bahamas indicating the potential for natural synthesis (Hodges et al. 2012). Detections at the Westport site provide some evidence for naturally occurring sources of this antibiotic in the marine environment.

Alkylphenol detections were widespread throughout the sites and did not have a strong pattern with proximity to wastewater. Four of the sites contained at least three of the four alkylphenols (Coos Bay, North Bend, Valino Island, and Westport) and concentrations were relatively similar across sites, except for Westport which had notably higher concentrations of NP1EO, and 4-NP. Widespread concentrations could be due to multiple sources, high usage of products in both household and industrial settings, and the bioaccumulative nature of the compounds. Septic systems, stormwater discharge and industrial activities can be significant sources of alkylphenols and at least one is present near each of these sites. Alkylphenols have higher $\log \mathrm{K}_{\text {ow }}$ values (e.g., 5.76 for 4-NP) 
than most pharmaceuticals and are therefore very likely to accumulate in tissues over time. The high detections and concentrations at Westport specifically could be due to higher inputs of compounds from upstream industrial activities and multiple wastewater treatment plants. The city of Hoquiam which is located approximately $19 \mathrm{~km}$ upstream of Westport supports several types of industrial production. There are also four wastewater treatment plants that discharge into the estuary and the Chehalis River. One of these is located just inside the mouth of the bay to the North of the study site. Grays Harbor has high tidal influence, especially near the mouth, which could be pushing effluent towards the site. There are also roads in close proximity to the site that could increase exposure to stormwater runoff. These factors could contribute overall to higher contamination in this estuary, but a specific source for the high concentration of 4-NP could not be easily identified.

The other two growout sites had lower levels of alkylphenols. Despite the lack of wastewater inputs at Valino Island, concentrations of NP2EO, 4-NP, and 4N-OP were comparable to those at wastewater sites (North Bend and Coos Bay). Residences with septic systems and low flushing rate could be reasons for similar detections. One growout site, Netarts Bay, had only two alkylphenol detections (NP2EO and 4-NP) and the lowest concentrations among all of the sites (Table 2.4). Netarts Bay is mainly surrounded by forestland, has a small surrounding population, a high flushing rate, and lacks a dominant freshwater input. These factors likely contribute to lower contamination at the Netarts site. 
In this study, we found that oyster condition did not vary based on wastewater proximity on a small spatial scale. At the two wastewater sites (North Bend and Coos Bay), there was no significant difference in oyster condition index across the racks placed at different distances from a wastewater outfall. However, at two oyster growout sites (Valino Island and Netarts) with racks spaced to account for environmental variability, we detected significant differences in oyster condition. This indicates that variability in environmental factors (e.g., nutrient availability, flow, sedimentation) at a small spatial scale could be a significant driver at these sites. Since differences in condition index were not apparent within wastewater sites, we hypothesize that effluent could be spanning a broader spatial scale than expected and affecting oysters within the range of the plume. This is further emphasized by results of condition index at the site level (Coos, North Bend, Valino Island, Netarts, Westport), where we found that wastewater sites had lower condition index than growout sites (Figure 2.4A). However, the weak pattern at wastewater exposed sites indicates that oysters may not show strong negative effects at the organism level when exposed to wastewater. Pacific oysters can thrive in variable environmental conditions (Pauley et al., 1988) and therefore may be able to adapt to poor conditions, including pollution exposure. This has implications for aquaculture since oyster condition is commonly used to determine oyster quality for consumption, and oysters may appear to be in good condition despite ambient pollution exposure. Additionally, suspended culture may reduce exposure to contaminants bound to sediments, which can be a secondary source of pharmaceuticals and alkylphenols, especially those with higher $\log \mathrm{K}_{\mathrm{ow}}$ values (Gaw et al. 2014). When the sediment is 
disrupted, compounds bound to the sediments can be released in the surrounding water. Therefore, oysters suspended above the ground would have less exposure to these resuspended compounds.

While we did not see strong effects on oysters in this study, PPCP effects on organisms have been documented in other research. Though previous research has not focused specifically on virginiamycin or miconazole, other antibiotics have been the focus of some experiments. For example, Teixeira and Granek (2017) showed that the antibiotic agents sulfamethoxazole and trimethoprim reduce marine microalgal growth in three weeks. Alkylphenols are endocrine disruptors and several studies have demonstrated their negative effects on aquatic and marine organisms. Nonylphenol, octylphenol and NP1EO can reduce body weight and length of juvenile female Rainbow trout (Oncorhynchus mykiss) when exposed to environmentally relevant concentrations of each compound individually (Ashfield et al. 1998). Other effects include feminization and decreased liver protein in adult male flounders (Platichthys flesus) (Christensen et al. 1999) and reduced byssus thread strength in Bay mussels (Mytilus edulis) (Granmo et al. 1989).

There may be concerns among the public about human health effects of consuming trace amounts of PPCPs in oysters. Generally, the amounts found in seafood are orders of magnitude lower than prescribed doses, thus therapeutic and/or associated side effects are unlikely to occur. The US FDA and Department of Agriculture (USDA) place strict regulations on the use of veterinary antibiotics in livestock farming and have set allowable levels of antibiotics in edible tissue, which are typically 100- to 1000-fold 
lower than no effect concentrations (Donoghue 2003). The levels reported here are significantly lower than the safe consumption level ( $250 \mathrm{mg} / \mathrm{kg}$ of body weight) and allowable level in meat (100 ng/g) (US FDA 2019), indicating that consumption of oysters with trace amounts of antibiotics does not pose a health risk. Additionally, nonylphenol concentrations in this study were well below the no effect levels for humans which range from 13-100 mg/kg of body weight per day (EPA 2010), again suggesting consumption of oysters with trace chemical levels is safe. Lastly, although these compounds were found in oysters near aquaculture sites, they originate from land-based sources, primarily household use, and are not associated with the oyster aquaculture industry. Therefore, these data to not indicate that consumption of farmed seafood is harmful to humans based on the contamination levels reported here.

This study had several limitations that should be considered for interpretation of results and future work. First of all, replication at the site level (wastewater vs. oyster growout) was low and uneven, with two wastewater sites and three oyster growout sites. Secondly, distances separating racks at both site types were inconsistent among sites and a lack of data pertaining to environmental variables at each rack limited conclusions about effects on oyster health. Lastly, due to funding limitations, PPCP analysis was limited to only a few samples and compounds, and was inconsistent among seasons (spring and summer). A better resourced research setup could focus on higher replication at the site level by identifying all possible wastewater exposed and aquaculture sites in OR and WA, and randomly choosing an even number of each type to compare, with higher replication than this study. We found that wastewater sites had slightly lower 
oyster condition and more pharmaceutical detections than oyster growout sites, therefore more replication of those site types could elucidate a stronger pattern, if it exists. To examine differences in contaminants and oyster health along a pollution gradient, we recommend placing oyster racks at consistent distances from wastewater outfalls among sites, and measuring covariates to account for environmental variability at all site types. We found that environmental variability was likely important at individual sites, but were unable to describe the specific drivers of these differences. Lastly, analyzing samples collected at different seasons for the same contaminants would be helpful in determining seasonal differences. We detected few compounds in the spring samples, but more may have been present in the summer when rain events were rare and PPCP inputs likely higher due to a heavy tourist season on the OR and WA coasts. Many of these challenges were driven by limited funding and resources, therefore increased funding to support larger scale studies is needed. Despite these limitations, this study reports useful data on PPCP occurrence and organism effects near wastewater at small spatial scales, with recommendations to inform future work.

\subsection{Conclusion}

Pacific oysters accumulated PPCPs in areas near wastewater and commercial production, with more detections and higher concentrations near wastewater sources. Concentrations were relatively low, and well below concerning levels for human consumption, indicating low PPCP occurrence in OR and WA estuaries with small human populations. We found that oyster condition was slightly lower at wastewater sites 
compared to oyster growout sites, thus pollution exposure may affect organism health. However, at a small spatial scale (among racks), oyster condition showed more variation at sites without wastewater influence, emphasizing the importance of environmental variability. We recommend that future studies expanding on this work increase replication at the site level, measure environmental covariates to more specifically characterize the role of environmental variability in PPCP occurrence and oyster health, and analyze multiple matrices (tissue, water, sediment) for more analytes.

\subsection{Acknowledgements}

We thank the Whiskey Creek Shellfish Hatchery for providing oyster spat, mesh, and a space to assemble the growout bags. We thank the oyster grower in Westport, WA for allowing us to place racks on the property. This research would not have been possible without A. Demarzo, A. Helms, and B. Yednock at the South Slough National Estuarine Research Reserve and T. D'Andrea and L. Perotti from Oregon Department of Fish and Wildlife who provided boat transportation, lab space, and access to sites at Valino Island and Netarts Bay. We thank S. Rumrill for key input on oyster rack design and assistance with field coordination. We thank the ACE lab for helpful feedback on an earlier draft, L. McKinney-Wise for creating site maps, and the many undergraduate and graduate student field and lab assistants. This work was supported by the National Science Foundation Integrative Graduate Education and Research Traineeship (IGERT) research funds and the Olive and Edward Bushby scholarship from Portland State University. 


\subsection{References}

Arpin-Pont L, Bueno MJM, Gomez E, Fenet H. 2016. Occurrence of PPCPs in the marine environment: a review. Environ Sci Pollut Res 23:4978-4991; doi:10.1007/s11356-014-3617-x.

Ashfield LA, Pottinger TG, Sumpter JP. 1998. Exposure of female juvenile rainbow trout to alkylphenolic compounds results in modifications to growth and ovosomatic index. Environmental Toxicology and Chemistry 17:679-686; doi:10.1002/etc.5620170423.

Barton A, Hales B, Waldbusser GG, Langdon C, Feely RA. 2012. The Pacific oyster, Crassostrea gigas, shows negative correlation to naturally elevated carbon dioxide levels: Implications for near-term ocean acidification effects. Limnol Oceanogr 57:698-710; doi:10.4319/10.2012.57.3.0698.

Bayen S, Zhang H, Desai MM, Ooi SK, Kelly BC. 2013. Occurrence and distribution of pharmaceutically active and endocrine disrupting compounds in Singapore's marine environment: influence of hydrodynamics and physical-chemical properties. Environ Pollut 182:1-8; doi:10.1016/j.envpol.2013.06.028.

Biel-Maeso M, Baena-Nogueras RM, Corada-Fernández C, Lara-Martín PA. 2018. Occurrence, distribution and environmental risk of pharmaceutically active compounds (PhACs) in coastal and ocean waters from the Gulf of Cadiz (SW Spain). Sci Total Environ 612:649-659; doi:10.1016/j.scitotenv.2017.08.279. 
Bischoff KM, Zhang Y, Rich JO. 2016. Fate of virginiamycin through the fuel ethanol production process. World J Microbiol Biotechnol 32:76; doi:10.1007/s11274016-2026-3.

Christensen LJ, Korsgaard B, Bjerregaard P. 1999. The effect of 4-nonylphenol on the synthesis of vitellogenin in the flounder Platichthys flesus. Aquatic Toxicology 46:211-219; doi:10.1016/S0166-445X(98)00129-5.

Compart DMP, Carlson AM, Crawford GI, Fink RC, Diez-Gonzalez F, DiCostanzo A, et al. 2013. Presence and biological activity of antibiotics used in fuel ethanol and corn co-product production1. Journal of Animal Science 91:2395-2404; doi:10.2527/jas.2012-5714.

Cortright R, Weber J, Bailey R. 1987. The Oregon Estuary Plan Book. Oregon Department of Land Conservation and Development: Oregon.

Daughton CG, Ternes TA. 1999. Pharmaceuticals and personal care products in the environment: agents of subtle change? Environ Health Perspect 107: 907-938.

Dodder NG, Maruya KA, Lee Ferguson P, Grace R, Klosterhaus S, La Guardia MJ, et al. 2014. Occurrence of contaminants of emerging concern in mussels (Mytilus spp.) along the California coast and the influence of land use, storm water discharge, and treated wastewater effluent. Marine Pollution Bulletin 81:340-346; doi:10.1016/j.marpolbul.2013.06.041.

Done HY, Halden RU. 2015. Reconnaissance of 47 antibiotics and associated microbial risks in seafood sold in the United States. Journal of Hazardous Materials 282:1017; doi:10.1016/j.jhazmat.2014.08.075. 
Donoghue D. 2003. Antibiotic residues in poultry tissues and eggs: human health concerns? Poultry Science 82:618-621; doi:10.1093/ps/82.4.618.

Dumbauld BR, Ruesink JL, Rumrill SS. 2009. The ecological role of bivalve shellfish aquaculture in the estuarine environment: A review with application to oyster and clam culture in West Coast (USA) estuaries. Aquaculture 290:196-223; doi:10.1016/j.aquaculture.2009.02.033.

Dumonceaux TJ, Hill JE, Hemmingsen SM, Kessel AGV. 2006. Characterization of Intestinal Microbiota and Response to Dietary Virginiamycin Supplementation in the Broiler Chicken. Appl Environ Microbiol 72:2815-2823;

doi:10.1128/AEM.72.4.2815-2823.2006.

Dzhavakhiya V, Savushkin V, Ovchinnikov A, Glagolev V, Savelyeva V, Popova E, et al. 2016. Scaling up a virginiamycin production by a high-yield Streptomyces virginiae VKM Ac-2738D strain using adsorbing resin addition and fed-batch fermentation under controlled conditions. 3 Biotech 6; doi:10.1007/s13205-0160566-8.

Elgethun K, Neumann C, Blake P. 2000. Butyltins in shellfish, finfish, water and sediment from the Coos Bay estuary (Oregon, USA). Chemosphere 41:953-964; doi:10.1016/S0045-6535(99)00560-3.

Fabbri E, Franzellitti S. 2016. Human pharmaceuticals in the marine environment: Focus on exposure and biological effects in animal species. Environ Toxicol Chem 35:799-812; doi:10.1002/etc.3131. 
Fent K, Weston AA, Caminada D. 2006. Ecotoxicology of human pharmaceuticals. Aquatic Toxicology 76:122-159; doi:10.1016/j.aquatox.2005.09.009.

Follansbee B, Mondragon J, Allen S, Mundell J. 1999. Netarts Watershed Assessment. Galtsoff PS. 1964. Morphology and structure of shell. Ch. 2. Fishery Bulletin of Fish and Wildlife Service 64: 16-47.

Gaw S, Thomas KV, Hutchinson TH. 2014. Sources, impacts and trends of pharmaceuticals in the marine and coastal environment. Philosophical Transactions of the Royal Society B: Biological Sciences 369:2013057220130572; doi:10.1098/rstb.2013.0572.

Glanzman C, Glenne B, Burgess F. 1971. Tidal Hydraulics, Flushing Characteristics and Water Quality of Netarts Bay.

Granek EF, Conn KE, Nilsen EB, Pillsbury L, Strecker AL, Rumrill SS, et al. 2016. Spatial and temporal variability of contaminants within estuarine sediments and native Olympia oysters: A contrast between a developed and an undeveloped estuary. Science of The Total Environment 557-558:869-879; doi:10.1016/j.scitotenv.2016.03.043.

Granmo A, Ekelund R, Magnusson K, Berggren M. 1989. Lethal and sublethal toxicity of 4-nonylphenol to the common mussel (Mytilus edulis L.). Environ Pollut 59:115127; doi:10.1016/0269-7491(89)90100-0.

Grays Harbor County. 2016. Water Quality. Available: http://www.co.graysharbor.wa.us/departments/public_services/MarineResourcesCommittee/MRCwate r_quality.php [accessed 14 December 2020]. 
Groth S, Rumrill S. 2009. History of Olympia Oysters (Ostrea lurida Carpenter 1864) in Oregon Estuaries, and a Description of Recovering Populations in Coos Bay. Journal of Shellfish Research 28:51-58; doi:10.2983/035.028.0111.

Gu Y, Yu J, Hu X, Yin D. 2016. Characteristics of the alkylphenol and bisphenol A distributions in marine organisms and implications for human health: A case study of the East China Sea. Science of The Total Environment 539:460-469; doi:10.1016/j.scitotenv.2015.09.011.

Hamdy MK, Toledo RT, Shieh CJ, Pfannenstiel MA, Wang R. 1996. Effects of Virginiamycin on fermentation rate by yeast. Biomass and Bioenergy 11:1-9; doi:10.1016/0961-9534(96)00007-4.

Hodges TW, Slattery M, Olson JB. 2012. Unique Actinomycetes from Marine Caves and Coral Reef Sediments Provide Novel PKS and NRPS Biosynthetic Gene Clusters. Mar Biotechnol 14:270-280; doi:10.1007/s10126-011-9410-7.

Hughes SR, Kay P, Brown LE. 2013. Global Synthesis and Critical Evaluation of Pharmaceutical Data Sets Collected from River Systems. Environ Sci Technol 47:661-677; doi:10.1021/es3030148.

Hunt CD, Slone E. 2010. Long-term monitoring using resident and caged mussels in Boston Harbor yield similar spatial and temporal trends in chemical contamination. Marine Environmental Research 70:343-357; doi:10.1016/j.marenvres.2010.07.002.

Hynes SH, Kjarsgaard DM, Thomas KC, Ingledew WM. 1997. Use of virginiamycin to control the growth of lactic acid bacteria during alcohol fermentation. Journal of 
Industrial Microbiology and Biotechnology 18:284-291;

doi:10.1038/sj.jim.2900381.

Ialongo C. 2016. Understanding the effect size and its measures. Biochem Med (Zagreb)

26:150-163; doi:10.11613/BM.2016.015.

James CA, Lanksbury J, Khangaonkar T, West J. 2020. Evaluating exposures of bay mussels (Mytilus trossulus) to contaminants of emerging concern through environmental sampling and hydrodynamic modeling. Science of The Total Environment 709:136098; doi:10.1016/j.scitotenv.2019.136098.

Jjemba PK. 2006. Excretion and ecotoxicity of pharmaceutical and personal care products in the environment. Ecotoxicology and Environmental Safety 63:113130; doi:10.1016/j.ecoenv.2004.11.011.

Juza H. 2000. Water Quality Model for South Slough, Coos Bay, Oregon.; doi:10.15760/etd.6922.

Klosterhaus SL, Grace R, Hamilton MC, Yee D. 2013. Method validation and reconnaissance of pharmaceuticals, personal care products, and alkylphenols in surface waters, sediments, and mussels in an urban estuary. Environment International 54:92-99; doi:10.1016/j.envint.2013.01.009.

Krogh J, Lyons S, Lowe CJ. 2017. Pharmaceuticals and Personal Care Products in Municipal Wastewater and the Marine Receiving Environment Near Victoria Canada. Front Mar Sci 4; doi:10.3389/fmars.2017.00415.

Lara-Martín PA, González-Mazo E, Petrovic M, Barceló D, Brownawell BJ. 2014. Occurrence, distribution and partitioning of nonionic surfactants and 
pharmaceuticals in the urbanized Long Island Sound Estuary (NY). Marine Pollution Bulletin 85:710-719; doi:10.1016/j.marpolbul.2014.01.022.

Lee II H, Brown CA. 2009. Classification of Regional Patterns of Environmental Drivers and Benthic Habitats in Pacific Northwest Estuaries.

Lucas A, Beninger PG. 1985. The use of physiological condition indices in marine bivalve aquaculture. Aquaculture 44:187-200; doi:10.1016/0044-8486(85)902431.

Maruya KA, Vidal-Dorsch DE, Bay SM, Kwon JW, Xia K, Armbrust KL. 2012. Organic contaminants of emerging concern in sediments and flatfish collected near outfalls discharging treated wastewater effluent to the Southern California Bight.

Environmental Toxicology \& Chemistry 31:2683-2688; doi:10.1002/etc.2003.

McCallum L. 1977. Netarts Bay, Oregon: an assessment of human impact on an estuarine system.

Meador JP, Yeh A, Young G, Gallagher EP. 2016. Contaminants of emerging concern in a large temperate estuary. Environmental Pollution 213:254-267; doi:10.1016/j.envpol.2016.01.088.

Mo C, Neilson B. 1994. Standardization of oyster soft tissue dry weight measurements. Water Research 28:243-246; doi:10.1016/0043-1354(94)90140-6.

Nilsen E, Furlong ET, Rosenbauer R. 2014. Reconnaissance of Pharmaceuticals and Wastewater Indicators in Streambed Sediments of the Lower Columbia River Basin, Oregon and Washington. Journal of the American Water Resources Association 50:291-301; doi:10.1111/jawr.12161. 
NOAA National Estuarine Research Reserve System (NERRS). 2020. System-wide Monitoring Program. Data accessed from the NOAA NERRS Centralized Data Management Office website. Available: http://cdmo.baruch.sc.edu/ [accessed 12 October 2012].

Olendorff SA, Chmielewska K, Tucker KR. Survey of Antibiotics Residues in DDGS from 14 Different States by LCMS. Cereal Chemistry n/a; doi:https://doi.org/10.1002/cche.10370.

Pauley GB, Van Der Raay B, Troutt D. 1988. Species Profiles: Life Histories and Environmental Requirements of Coastal Fishes and Invertebrates (Pacific Northwest), Pacific Oyster.

Prichard E, Granek EF. 2016. Effects of pharmaceuticals and personal care products on marine organisms: from single-species studies to an ecosystem-based approach. Environmental Science and Pollution Research 23:22365-22384; doi:10.1007/s11356-016-7282-0.

Rainer JS, Mann R. 1992. A comparison of methods for calculating condition index in eastern oysters Crassostrea virginica (Gmelin, 1791). Journal of Shellfish Research 11: 55-58.

Rodriguez del Rey Z, Granek EF, Buckley BA. 2011. Expression of HSP70 in Mytilus californianus following exposure to caffeine. Ecotoxicology 20:855-861; doi:10.1007/s10646-011-0649-6. 
Ruhoy IS, Daughton CG. 2007. Types and quantities of leftover drugs entering the environment via disposal to sewage — Revealed by coroner records. Science of The Total Environment 388:137-148; doi:10.1016/j.scitotenv.2007.08.013.

Shirzad FF, Orlando SP, Klein CJ, Holliday SE, Warren MA, Monaco ME. 1988. Physical and Hydrologic Characteristics, the Oregon Estuaries. Strategic Assessment Branch, Ocean Assessments Division, Office of Oceanography and Marine Assessment, National Ocean Service, National Oceanic and Atmospheric Administration.

Smolders R, Bervoets L, Wepener V, Blust R. 2003. A conceptual framework for using mussels as biomonitors in whole effluent toxicity. Human and Ecological Risk Assessment 9: 741-760.

Souder J. 2016. Chapter 5: Zoning and Land Use. In: Communities, Land, and Waterways Data Source: Exploring our Essential Elements.

Sutherland DA, O’Neill MA. 2016. Hydrographic and dissolved oxygen variability in a seasonal Pacific Northwest estuary. Estuarine, Coastal and Shelf Science 172:4759; doi:10.1016/j.ecss.2016.01.042.

Teixeira JR, Granek EF. 2017. Effects of environmentally-relevant antibiotic mixtures on marine microalgal growth. Science of The Total Environment 580:43-49; doi:10.1016/j.scitotenv.2016.11.207.

US Census Bureau. 2019. U.S. Census Bureau QuickFacts: Coos Bay city, Oregon; North Bend city, Oregon. Available: 
https://www.census.gov/quickfacts/fact/table/coosbaycityoregon,northbendcityore gon/PST045218\#PST045218 [accessed 23 January 2020].

US EPA. 2010. Nonylphenol (NP) and Nonylphenol Ethoxylates (NPEs) Action Plan. Assessing and Managing Chemicals under TSCA. Available: https://www.epa.gov/assessing-and-managing-chemicals-under-tsca/nonylphenolnp-and-nonylphenol-ethoxylates-npes [accessed 22 April 2019].

US FDA. 1998. Guidance for Industry: Environmental Assessment of Human Drug and Biologics Applications. Available: https://www.gmpcompliance.org/guidelines/gmp-guideline/fda-guidance-for-industryenvironmental-assessment-of-human-drug-and-biologics-applications [accessed 14 January 2020].

US FDA. 2019. CFR - Code of Federal Regulations Title 21. US Food and Drug Administration. Available: https://www.accessdata.fda.gov/scripts/cdrh/cfdocs/cfcfr/CFRSearch.cfm?CFRPa $\underline{\mathrm{rt}=556 \& \text { showFR }=1}$ [accessed 3 December 2020].

US FDA. 2015. Hydrographic Studies of Wastewater Treatment Plant Discharges in Coos Bay, Oregon.

Vieno N, Tuhkanen T, Kronberg L. 2007. Elimination of pharmaceuticals in sewage treatment plants in Finland. Water Research 41:1001-1012; doi:10.1016/j.watres.2006.12.017. 
WA DOE. 2015. Final Environmental Impact Statement Control of Burrowing Shrimp using Imidacloprid on Commercial Oyster and Clam Beds in Willapa Bay and Grays Harbor, Washington. 


\title{
Chapter 3: PPCPs in coastal wastewater treatment plant effluent and effects on Pacific oysters
}

\begin{abstract}
Municipal wastewater treatment plant (WWTP) effluent is a primary source of pharmaceutical and personal care products (PPCPs) to the marine environment as most of these compounds are not fully removed during the treatment process. Continual discharge from WWTPs into coastal areas may act as a stressor by continually exposing organisms to a suite of PPCPs. To quantify effects of PPCP mixtures on wildlife, we conducted a lab experiment that exposed Pacific oysters to effluent from two Oregon coastal WWTPs of different discharge capacities ( $<1$ million gallons/day and >1 million gallons/day). Oysters were distributed across six treatments: $10 \%$ and $25 \%$ composite effluent from each treatment plant, $50 \%$ grab effluent from one treatment plant, and a seawater control (0\% effluent). At 6 and 12 weeks, various organismal endpoints were examined. Effluent was collected weekly during the study and analyzed for PPCPs. A subset of oysters from week 12 were freeze-dried and analyzed for PPCPs. Though few effects on oysters were measured during the 12 weeks of exposure, 30 PPCPs and three alkylphenols were detected in effluent and 13 PPCPs and four alkylphenols were detected in oyster tissue. Although PPCPs were abundant in effluent and accumulated in oyster tissue over three months, concentration had little effect on growth, feeding rates, and condition. This finding may point to acclimation of oysters to these persistent stressors or limited detection due to overall lower fitness following the experimental period.
\end{abstract}




\subsection{Introduction}

Municipal wastewater treatment plant (WWTP) effluent is a primary source of emerging contaminants to the marine environment. Treated effluent contains a mixture of compounds including pesticides, steroid hormones, and pharmaceutical and personal care products (PPCPs; drugs, supplements, antimicrobials, preservatives, fragrances, surfactants) (Vidal-Dorsch et al. 2012). Many PPCPs persist after use, excretion, and household disposal and are not fully removed during the wastewater treatment process (Vieno et al. 2007). Consequently, PPCPs are frequently detected in effluent (e.g., LaraMartín et al. 2014; Meador et al. 2016; Biel-Maeso et al. 2018), as well as marine water, organism tissue, and sediment (Arpin-Pont et al. 2016). Approximately 20,000 prescription drugs are currently approved for market use by the United States (US) Food and Drug Administration (FDA 2019) and in the US $48 \%$ of people report using at least one prescription drug in the last 30 days (CDC 2020). A handful of drugs, such as diclofenac, ibuprofen, and sulfamethoxazole, have been identified as concerning environmental pollutants due to toxicity, detection frequency, and/or concentration levels (Guruge et al. 2019; Papageorgiou et al. 2016; Rivera-Jaimes et al. 2018). These represent only a small fraction of currently used drugs and further research is needed to identify pharmaceuticals in marine environmental matrices and their subsequent risks. Alkylphenols, which constitute a variety of surfactants used in household and industrial products, are commonly detected in effluent and organism tissues, and are more bioaccumulative and toxic than most pharmaceuticals. Many studies have identified endocrine disruptive effects of alkylphenols on various species (Acir and Guenther 2018). 
Alkylphenols are classified into two categories: alkylphenol ethoxylates (APEOs) surfactants found in detergents, cleaners, cosmetics, paints, indoor pesticides and other products, and metabolites used in the production of APEOs such as nonylphenol (NP) and octylphenol (OP) (US EPA 2010). Following wastewater treatment and environmental degradation, APEOs break down into their associated metabolites, many of which are more persistent and toxic (US EPA 2010).

Concentrations and removal rates of PPCPs in WWTPs vary based on effluent flow rates, size of the source population and the type of wastewater treatment (Daughton and Ternes 1999; Gaw et al. 2014). When flows are higher, (e.g., during heavy rain events), removal efficiency is lower because PPCPs spend less time going through the breakdown process at the plant (Gaw et al. 2014). For example, Ternes (1998) found that removal rates of some drugs decreased from $60 \%$ to under $5 \%$ with heavy winter runoff. Most WWTPs in the United States employ primary and secondary treatment. Tertiary treatments such as ozonation are more effective in removing pharmaceuticals than secondary treatment, but are rarely implemented due to their cost (Castiglioni et al. 2006; Ternes et al. 2003). In general, removal rates for pharmaceuticals range from less than $10 \%$ to $100 \%$ (Gaw et al. 2014). For example, Lara-Martín et al. (2014) found that drugs were removed at varying percentages from a WWTP in New York City, NY with the antiepileptic drug, carbamazepine, removed at a rate of $42 \%$, the antihypertensive, propranolol, at $35 \%$, and the antibiotic, clarithromycin, at $15 \%$. In a study in Spain, only $25 \%$ of targeted pharmaceuticals in WWTP influent were efficiently removed during treatment (85\% or greater removal) (Biel-Maeso et al. 2018). Alkylphenols, which have 
higher octanol-water partitioning coefficients $\left(\log \mathrm{K}_{\mathrm{ow}}\right)$ than pharmaceuticals, are more likely to bind to sediment during wastewater treatment and be eliminated (Priac et al. 2017).

In populated coastal areas, WWTPs outfalls are commonly located near rocky shorelines and in bays and rivers that drain into the ocean. Continual discharge from WWTPs exposes organisms to mixtures of PPCPs, which may have negative effects on their health. Studies on individual PPCPs have shown that chronic exposure leads to various organismal effects (Fent et al. 2006; Peters and Granek 2016), but questions remain about exposure to multiple compounds simultaneously. Studies on whole effluent mixture effects are rare, though when conducted typically use high concentrations that elicit significant sub-lethal effects (e.g., Aerni et al. 2004; Wehmas et al. 2011; Vajda et al. 2015; Harding et al. 2016; Freitas et al. 2017). For example, Vajda et al. (2015) saw a reduction in testes stage in fish exposed to $50 \%$ and $100 \%$ effluent after 28 days. Most studies to date take place on short timelines (3-28 days) and focus on fish (e.g., Aerni et al. 2004; Wehmas et al. 2011; Minarik et al. 2014; Vajda et al. 2015; Cavallin et al. 2016; Harding et al. 2016), though a few studies have examined short-term effects on marine bivalves with resulting effects at molecular and cellular levels (Díaz-Garduño et al. 2018; Dumas et al. 2020; Flores-Nunes et al. 2015; Medeiros et al. 2008). A study that compared Pacific oyster exposure to whole effluent and a single contaminant in effluent (linear alkylbenzene), found that after 36 hours there were different responses in several endpoints (Flores-Nunes et al. 2015). This indicates potential synergistic and/or antagonistic effects and emphasizes the importance of examining toxic effects of 
contaminant mixtures. Further investigation is needed regarding effects of long-term exposure (>30 days) on sessile marine bivalves, which may be more susceptible to pollution than mobile organisms.

Pacific oysters (Crassostrea gigas) are a prominent aquaculture species on the US west coast, comprising $89 \%$ of shellfish aquaculture production in this area (Dumbauld et al. 2009). They are commonly grown in Oregon and Washington estuaries using ground culture, among other methods (Dumbauld et al. 2009) and provide important food and economic resources. As sessile, filter-feeding bivalves, they are susceptible to pollutant exposure. Additionally, prior research has shown that oysters are suitable for environmental toxicity determination (Palmer et al. 2015) and accumulate contaminants from the surrounding environment in their tissues. Understanding uptake of PPCPs in effluent and their effects on oysters is important for informing policies relating to safe aquaculture, ecological functions provided by oysters, and human health.

In Oregon, coastal cities are considerably smaller than many populated coastlines in the United States ranging from approximately 300 (Nehalem) to 16,000 (Coos Bay) people. Along the Oregon coast, there are 17 sewage treatment plants that discharge directly to an estuary or the ocean with discharge rates ranging from less than one million gallons per day (mgd) to five mgd (Oregon Department of Environmental Quality personal communication 2015).

In this experiment, we examine PPCP uptake and effects in Pacific oysters following exposure to effluent from Oregon coastal WWTPs. Our research objectives were to: 
1) Determine PPCP types and concentrations in effluent from the Oregon coast

2) Examine uptake of PPCPs by Pacific oysters following exposure to WWTP effluent

3) Identify organism level effects (growth, condition index, feeding rate) of chronic effluent exposure on Pacific oysters

4) Compare PPCP concentrations, uptake, and effects from effluent at two Oregon coastal WWTPs with different discharge capacities

\subsection{Methods}

\subsubsection{Source Wastewater Treatment Plants}

In a lab experiment conducted at Portland State University (PSU), adult Pacific oysters were exposed to different dilutions of effluent from WWTPs located on the northern Oregon coast. WWTP identities are anonymous per agreements with the operators who supplied effluent. The flow information was obtained from the associated National Pollutant Discharge Elimination System (NPDES) permits (not cited to maintain anonymity). The first treatment plant (WWTP1) processes <1 mgd and uses secondary treatment, specifically activated sludge and ultraviolet disinfection. The average flow from May to October is $0.18 \mathrm{mgd}$ and the surrounding population is around 1,300 people. The second treatment plant (WWTP2) is permitted to process $>1 \mathrm{mgd}$, but $<2 \mathrm{mgd}$ with secondary treatment of activated sludge and chlorine disinfection. The actual average flow of WWTP2 is $0.71 \mathrm{mgd}$ from May to October and the surrounding population is approximately 8,000 people. On week three of the experiment, the operator of WWTP2 
refused to continue providing effluent, after agreeing initially to participate in the 12week study. At this point, we secured agreement from another coastal WWTP with the same permitted discharge capacity as a replacement. The average flow from May to October is $1.08 \mathrm{mgd}$, slightly higher than the initial WWTP, but within the discharge range we were targeting. This plant utilizes activated sludge and ultraviolet disinfection as secondary treatment and has a surrounding population of approximately 6,700 people.

\subsubsection{Experimental Design and Animal Care}

On May 2, 2018, donated adult Pacific oysters were picked up from an oyster grower in Netarts Bay, OR. This estuary was chosen because it is considered relatively pristine due to low surrounding population, lack of dominant freshwater input, and heavy marine influence (high flushing rate). The oysters were kept in a clean holding tank for two weeks and then nine oysters were added to each of 24 individual experimental tanks (2.5 gallons), with artificial seawater made from Instant Ocean at a salinity of $25 \mathrm{ppt}$. Oysters acclimated in the tanks for six weeks before the experiment began. Tanks were randomly assigned one of six treatments, with four tanks per treatment: $10 \%$ and $25 \%$ composite effluent dilutions for each WWTP, a 0\% effluent control, and a 50\% grab effluent dilution from WWTP2 (Figure 3.1). The composite concentrations were chosen to represent environmentally relevant concentrations of exposure within the limits of available composite effluent samples. Each WWTP was able to provide a 24-hour composite sample of a maximum of 10 L. Since composite samples were limited, we used a grab sample as a $50 \%$ exposure for comparison to other studies that found 
significant negative effects at this concentration. Due to a limited number of tanks in our lab (24), we were only able to examine this exposure for one treatment plant.

Three times per week, oysters were fed Shellfish Diet 1800 from Reed Mariculture, Inc., a refrigerated mixture of five microalgal species commonly used to feed cultured bivalves. The amount fed was based on manufacturer recommendations and was adjusted as oysters were removed from tanks for analysis. A 25\% water change was performed on every tank weekly on the day before dosing occurred, to minimize dilution of effluent from the previous week.

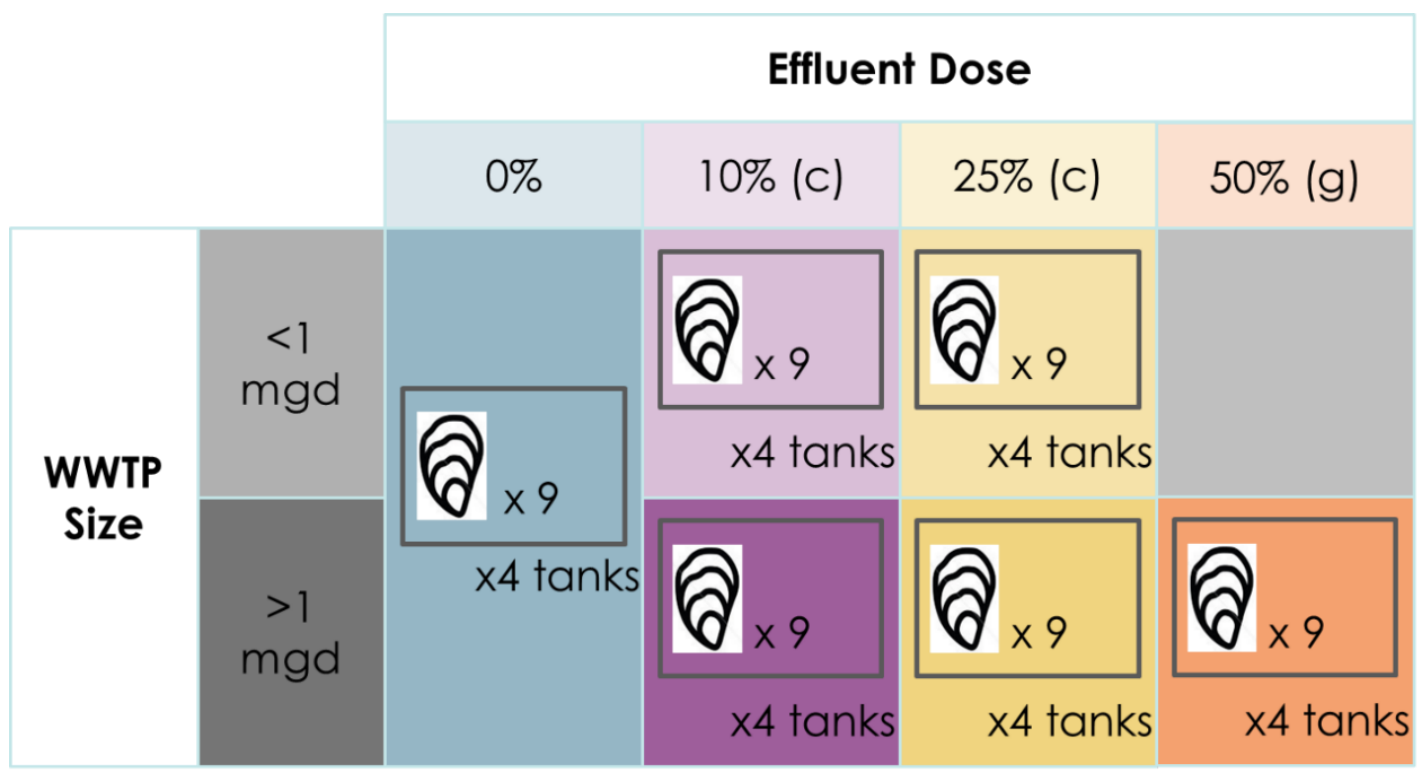

Figure 3.1 Schematic of experimental design for effluent exposure lab study where oysters were exposed to composite (c) and grab (g) samples of effluent at concentrations of 10,25, and 50\% effluent. Oysters were sampled at two time periods - 6 and 12 weeks.

\subsubsection{Effluent Collection, Transport, and Dosing}

The experiment began on June 27, 2018 and ran for 12 weeks. We collected 24hour composited effluent samples weekly on Thursdays from both treatment plants and a grab sample from the larger treatment plant. In weeks 9 and 10, WWTP1 was not able to provide composite effluent and in week 2, WWTP2 was not able to provide composite 
effluent, so corresponding tanks were left untreated at those dosing periods. Effluent was transported in 5-gallon buckets to Portland State University. Upon arrival, salt was added to bring the salinity to the ambient salinity in the experimental tanks ( $25 \mathrm{ppt}$ ) to reduce stress caused by salinity fluctuations. The appropriate amount of tank water was then removed from each tank and replaced with effluent. To mimic the dosing procedure, a $25 \%$ water change was performed on control tanks using the same methods. Gloves and lab coats were worn at all times during dosing and care was taken to prevent crosscontamination among treatments and controls by changing gloves and using designated tools for each treatment.

\subsubsection{Biological Measurements}

At 0, 6 and 12 weeks, oyster shell dimensions (length, width, height) and whole wet weight were measured for all oysters. Three oysters from each tank were sacrificed on each sampling date to measure wet tissue weight, dry tissue weight, and dry shell weight. The weighed wet tissues were frozen in pre-cleaned glass jars with PTFE lined caps at -20 degrees F. All oysters were dried to be analyzed for condition index, a proxy for oyster health expressed as the ratio of dry tissue weight to dry shell weight (Lucas and Beninger 1985).

\section{Equation 1: CI = dry tissue weight $x$ 100/dry shell weight}

All shells were air dried for 24 hours and weighed. Following the methods of Mo and Neilson (1994), oyster tissues from weeks 0 and 6 were thawed and dried in porcelain crucibles in a drying oven at 105 degrees $\mathrm{C}$ to constant weight (48-96 hours). To preserve 
samples from week 12 for PPCP analysis, oyster tissues were freeze dried in a Harvest Right freeze dryer for a 24-hour automatic cycle. Limited access to a freeze drier and partial funding for PPCP tissue analysis only allowed for using this method for the last sampling point. To determine if freeze- and oven-dried tissue weights could be compared across sample weeks, we selected a subset of oysters from each group (freeze- and ovendried) with similar wet tissue weights and graphed the dry weights against the wet weights (Figure A1). This comparison showed that both drying methods yielded similar dry weights with no consistent pattern of one weighing less or more. Therefore, condition index was compared across samples dates with different tissue drying methods.

To measure feeding rate (algal clearance rate), we took $10 \mathrm{~mL}$ samples of tank water within 20 minutes of feeding, diluted them in filtered seawater by a factor of 100 (100 uL of tank water in $10 \mathrm{~mL}$ of diluent), and used a Beckman Coulter Counter to count the number of algal cells in three to five $0.5 \mathrm{~mL}$ aliquots. Sampling and cells counts were repeated 3-5 hours after feeding. To account for settling of algae on tank surfaces, we set up four tanks without oysters and performed the same sampling methods. Algal clearance rate was calculated using the following equation (Coughlan 1969):

Equation 2: $C R=(V / n)\left[\ln \left(C_{0} / C_{t}\right) / t\right]-\left[\ln \left(C_{0}{ }^{\prime} / C_{t}{ }^{\prime}\right) / t\right]$

In the equation, $\mathrm{CR}=$ clearance rate $(\mathrm{mL} / \mathrm{min}), \mathrm{V}=$ tank volume $(\mathrm{mL}), \mathrm{n}=$ number of oysters per tank, $\mathrm{t}=$ time $(\mathrm{min}), \mathrm{C}_{0}=$ initial algal concentration $($ cells $/ \mathrm{mL}), \mathrm{C}_{\mathrm{t}}=$ algal concentration at the end of the test period (cells $/ \mathrm{mL}), \mathrm{C}_{0}{ }^{\prime}=$ initial algal concentration of tank without oysters (cells $/ \mathrm{mL})$, and $\mathrm{C}_{\mathrm{t}}{ }^{\prime}=$ algal concentration at the end of the test period in tank without oysters (cells/mL). Feeding rate was measured in weeks 6, 7, 10, and 12 . 


\subsubsection{Effluent and Tissue Analysis for PPCPs}

In addition to effluent for dosing, we collected a $500 \mathrm{~mL}$ effluent sample each week in an I-Chem certified clean amber glass jar with a PTFE lined cap for PPCP analysis. These samples were transported in a cooler to PSU and immediately frozen at 20 degrees F upon arrival. Due to funding constraints, the weekly effluent samples were composited into one sample for each WWTP by adding an even volume ( 100 mL) of each sample to two 1-liter containers, one for PPCPs and one for alkylphenols. Many of the bottles containing frozen effluent were broken upon inspection. To obtain these samples, effluent was thawed long enough to release from the glass, and then the frozen portion was moved to a methanol rinsed foil tray to thaw. Samples were put in clean, methanol rinsed amber glass jars and refrigerated until composited. Freeze-dried oyster tissues from week 12 exposed to $25 \%$ effluent from each treatment plant and controls were prepared for analysis. Three oysters from each tank were homogenized in a blender, split in half, then composited so that each sample consisted of three half oysters, with three composite samples per treatment plant and two controls. With limited funding, we chose to replicate analysis of the higher exposure rather than run few replicates of both exposure levels, as this would be expensive and redundant. The additional half oysters were set aside for a supplementary project that examined PPCP and microplastic analysis and co-occurrence of these contaminants.

In September 2020, composite effluent and tissue samples were analyzed for PPCPs and alkylphenols at SGS AXYS Analytical Services in Sydney, British Columbia. 
Each sample was analyzed for 58 PPCPs (Figure D1 and D2) and 4 alkylphenols: two nonylphenol ethoxylates (NPEOs), 4-nonylphenol monoethoxylate (4-NP1EO) and 4nonylphenol diethoxylate (4-NP2EO), and two breakdown products, 4-nonylphenol (4NP) and 4-n-octylphenol (4-n-OP). The following is a brief summary of standard protocols and methods provided by SGS AXYS Analytical for PPCP and alkylphenol target analysis. PPCP samples in effluent and tissues were adjusted to a $\mathrm{pH}$ of two prior to extraction. Tissue samples were extracted using sonication with aqueous buffered and pure acetonitrile, and aqueous samples were filtered. Tissue extracts and the aqueous portion of effluent samples were cleaned up using solid phase extraction (SPE) and analyzed with high performance liquid chromatography electrospray ionization tandem mass spectrometry (LC/ESI-MS/MS). Alkylphenol tissue samples were mixed with water and extracted by steam distillation into isooctane. Samples were cleaned up with SPE, prepared in methanol and analyzed by LC/ESI-MS/MS in two runs, one in ESI positive mode and one is ESI negative mode. Alkylphenol effluent samples were extracted with hexane and derivatized by non-aqueous acetylation. Samples were cleaned up by chromatography on a $28 \%$ deactivated silica column and analyzed with gas chromatography mass spectrometry (GC-MS). All samples were spiked with surrogate standards prior to extraction and spiked with recovery standards prior to analysis.

\subsubsection{Data Analysis}

All analyses were performed in Microsoft Excel and R version 3.4.1. Summary statistics (mean and standard deviation) of oyster growth dimensions (shell height, length, 
width, whole weight, wet tissue weight, condition index) were calculated for each tank at the three sampling points. Change in growth was determined for shell height (distance between the umbo and ventral valve) and whole weight (mass) through the following equation: Dimension ${ }_{t}-$ Dimenstion $_{0}$. Analyses for change in mass and shell height were performed on within-tank means of six oysters at week 6 and three oysters at weeks 12 . For condition index and wet tissue weight, analyses were performed on within-tank means of three sacrificed oysters at each sampling date $(0,6,12)$. We used a two-way mixed ANOVA, an extension of repeated measures ANOVA, to determine statistical significance of change in mass, change in height, wet tissue weight and condition index for each treatment (effluent dose) and sample week. Exposures from each treatment plant were analyzed separately, as well as the grab samples from WWTP 2. For the ANOVA, treatment was considered a between-group factor and sample week was considered a within-group factor. Assumptions were assessed using quantile-quantile plots and Shapiro-Wilk tests for normality, Levene's test for equal variance, Box's M-test for homogeneity of covariances, and the Mauchly's test for sphericity. For mass, height, and condition index, all data met the assumptions for parametric mixed ANOVA. For wet tissue weight, the WWTP2 grab samples did not meet the equal variance assumption even with transformation, so a robust ANOVA, which does not assume equal variance (Mair and Wilcox 2019), was used instead. Post-hoc comparisons were made with pairwise ttests and a Bonferroni correction where applicable.

Feeding rates were calculated for each tank at each sampling point on weeks 6, 7, 10 , and 12 . Approximately $50 \%$ of measurements from the empty control tanks $\left(\mathrm{C}_{\mathrm{t}}{ }^{\prime} / \mathrm{C}_{0}{ }^{\prime}\right)$ 
resulted in values that were not representative of settling. Specifically, $\mathrm{C}_{\mathrm{t}}$ ' was lower than $\mathrm{C}_{0}$ ' or the difference between $\mathrm{C}_{\mathrm{t}}{ }^{\prime}$ and $\mathrm{C}_{0}$, , was larger than the difference between $\mathrm{C}_{\mathrm{t}}$ and $\mathrm{C}_{0}$. Both of these conditions resulted in a negative feeding rate. Therefore, the settling term, $\left[\ln \left(C_{0}{ }^{\prime} / C_{t}{ }^{\prime}\right) / t\right]$, was omitted from the feeding rate equation. Over the course of all feeding trials, 14 calculations resulted in negative feeding rates due to $C_{t}$ values being higher than $\mathrm{C}_{0}$ values in individual tanks. These tanks were removed for graphical and statistical analysis of clearance rates. If more than one tank was removed from each treatment, leaving less than three replicates, the treatment was excluded from statistical analysis. Due to a loss of two control tanks ( $0 \%$ effluent) during week 10 feeding trials, all week 10 samples were excluded from analysis. To achieve even sample sizes for ANOVA, at each sampling week, remaining treatments with four tanks were reduced to three tanks using a random number generator to remove one tank. Since different tanks were removed at each sampling point, repeated measures ANOVA was deemed inappropriate for analysis (some tanks were not repeatedly measured). Instead, one-way ANOVA was used to analyze differences in feeding rate among treatments at each sample week. Post-hoc comparisons were made with Tukey's HSD test. Data met all assumptions prior to analysis.

Combined total contaminant concentrations in effluent from the two treatment plants were compared using a t-test. Data were log transformed to meet assumptions of normality and equal variance.

Bioaccumulation factors (BAFs) were calculated for each tissue sample using the following equation: 


\section{Equation 3: BAF = Tissue Concentration/Water Concentration}

To determine the approximate water concentration, effluent concentrations were multiplied by 0.25 , to account for $25 \%$ dilution in the tanks.

We ran a post hoc power analysis on the observed effect sizes from the experiment to examine recommended sample sizes. Since practical methods are not available for a mixed ANOVA, we ran one-way ANOVAs on the 12-week results for each response variable. Therefore, the results do not address effects over time. We used Cohen's $f$ as a measure of effect size (Ialonga 2016), set alpha at 0.05 and power at 0.80 , and calculated sample size using the R package, pwr.

\subsection{Results}

\subsubsection{Oyster Size, Condition and Feeding Rate}

Throughout the experiment, mortality was low (1.3\%) and deaths were dispersed among treatments, indicating that tank environments were suitable for oyster survival and effluent did not induce mortality in any concentration. Summary statistics of oyster dimensions, condition index, and change in growth are reported in Tables 3.1 and 3.2. Over the course of the experiment, a small amount of shell growth occurred, with increase in shell height ranging from 0-5.62 $\mathrm{mm}$ from week 0-6 and 0-6.28 $\mathrm{mm}$ from week $0-12$. The mean change in shell height was $0.51 \mathrm{~mm}$ for week $0-6$ and 0.96 for weeks $0-12$, suggesting that most oysters experienced minimal shell growth. Control oysters had a significant increase in shell height from week 6 to 12 (Paired t-test: $\mathrm{p}=.031$ ) as did oysters in WWTP2 (composite: ANOVA: $\mathrm{F}_{1,9}=11.640, \mathrm{p}=.008$; grab: ANOVA: 
$\mathrm{F}_{1,6}=13.304, \mathrm{P}=.011$ ), while treatments with WWTP1 effluent did not (10\%: paired t-test: $\mathrm{p}=.406 ; 25 \%$ : paired t-test: $\mathrm{p}=.077$ ), though the increase in the $25 \%$ treatment was marginally significant (Figure 3.2, Table 3.3). In WWTP2, there was a marginally significant difference in shell height between treatments at week 6 (ANOVA: $F_{2,9}=3.833$, $\mathrm{p}=.070$ ), with the $10 \%$ effluent treatment having lower change in shell height compared to the $25 \%$ treatment (paired t-test: $\mathrm{p}=.099$ ).

Oyster mass was similar among treatments at each sampling point, with an overall decrease from week 0 to 6 in all treatments (Figure 3.2). From week 6 to 12, oysters regained some weight, but did not reach or surpass their original mass. The increase in mass from week 6 to 12 was marginal for both WWTP1 (ANOVA: $\mathrm{F}_{1,9}=3.993$, $\mathrm{p}=.077$ ) and WWTP2 (ANOVA: $\mathrm{F}_{1,9}=4.942, \mathrm{P}=.053$ ). In both WWTPs, wet tissue weight was relatively similar across sample weeks. In WWTP2, wet tissue weight decreased marginally over time (ANOVA: $\mathrm{F}_{2,18}=2.727, \mathrm{p}=.092$ (Figure 3.3, Table 3.3).

Condition index decreased over time in all treatments from both WWTPs (ANOVA: WWTP1: $\mathrm{F}_{2,18}=11.578, \mathrm{p}<.001$; WWTP2: $\mathrm{F}_{2,18}=27.409$, $\mathrm{p}<.001$; WWTP2(grab): $\mathrm{F}_{2,12}=9.371, \mathrm{p}=.004$ ) and did not vary by effluent concentration (Figure 3.3, Table 3.3). Specifically, condition index was significantly lower at week 6 and week 12 compared to week 0 (Paired t-test: WWTP1: 0-6: p=.02, 0-12: p=.001; WWTP2: 0-6: $\mathrm{p}=.001,0-12: \mathrm{p}<.001$; WWTP2(grab): 0-6: $\mathrm{p}=.05,0-12: \mathrm{p}=.005$ ) (Figure 3.3, Table 3.3).

Over the three sampling weeks, only one significant difference was identified in feeding rate (Figure 3.4, Table 3.4). In the week 6 trial, the $10 \%$ effluent treatment from WWTP1 had significantly higher algal clearance than the control and 25\% treatment 
(ANOVA: $\mathrm{F}_{2,6}=10.269, \mathrm{p}=.01$ ) (Figure 3.4, Table 3.4). Also, oysters in the $50 \%$ grab treatment had marginally higher clearance rates than the the control (t-test: $t_{4}=-2.325$, $\mathrm{p}=.081)$. Overall, feeding rates showed an increase over time with high variation and no further significant differences.

The power analysis resulted in recommended sample sizes ranging from 2-322 replicates with most of the values within the range of 6-30 replicates (Table 3.7). This shows that for most of the responses measured, a higher sample size may have been necessary to identify significant effects.

Table 3.1 Summary statistics (mean and standard deviation) of oyster dimensions for each treatment at three sampling dates. Oysters were exposed to composite effluent from two treatment plants at $10 \%$ and $25 \%$ concentrations, and $50 \%$ grab effluent from WWTP2. Summaries represent the average of three oysters sampled per tank and averaged for each treatment ( $\mathrm{n}=4$ tanks per treatment) at each sampling week.

\begin{tabular}{|c|c|c|c|c|c|c|c|}
\hline $\begin{array}{l}\text { Effluent } \\
\text { Concentration }\end{array}$ & $\begin{array}{l}\text { Sample } \\
\text { Week }\end{array}$ & Mass (g) & $\begin{array}{l}\text { Height } \\
(\mathbf{m m})\end{array}$ & $\begin{array}{l}\text { Length } \\
\text { (mm) }\end{array}$ & $\begin{array}{l}\text { Width } \\
\text { (mm) }\end{array}$ & $\begin{array}{l}\text { Wet } \\
\text { Tissue } \\
\text { Weight } \\
\text { (g) }\end{array}$ & $\begin{array}{l}\text { Condition } \\
\text { Index }\end{array}$ \\
\hline \multicolumn{8}{|l|}{ Control } \\
\hline $0 \%$ & 0 & $\begin{array}{l}38.74 \\
(2.71)\end{array}$ & $\begin{array}{l}82.2 \\
(4.56)\end{array}$ & $\begin{array}{l}46.06 \\
(1.39)\end{array}$ & $\begin{array}{l}20.82 \\
(3.16)\end{array}$ & $\begin{array}{l}7.92 \\
(1.03)\end{array}$ & $\begin{array}{l}5.04 \\
(0.55)\end{array}$ \\
\hline $0 \%$ & 6 & $\begin{array}{l}43.15 \\
(4.78)\end{array}$ & $\begin{array}{l}86.32 \\
(5.36)\end{array}$ & $\begin{array}{l}52.76 \\
(5.19)\end{array}$ & $\begin{array}{l}19.76 \\
(1.17)\end{array}$ & $\begin{array}{l}8.95 \\
(0.39)\end{array}$ & $\begin{array}{l}4.02 \\
(0.92)\end{array}$ \\
\hline $0 \%$ & 12 & $\begin{array}{l}37.73 \\
(3.9)\end{array}$ & $\begin{array}{l}78.36 \\
(6.55)\end{array}$ & $\begin{array}{l}55.04 \\
(2.92)\end{array}$ & $\begin{array}{l}19.71 \\
(0.85)\end{array}$ & $\begin{array}{l}7.47 \\
(1.03)\end{array}$ & $\begin{array}{l}3.76 \\
(0.76)\end{array}$ \\
\hline \multicolumn{8}{|l|}{ WWTP1 } \\
\hline $10 \%$ & 0 & $\begin{array}{l}40.93 \\
(8.68)\end{array}$ & $\begin{array}{l}79.76 \\
(3.55)\end{array}$ & $\begin{array}{l}50.5 \\
(3.78)\end{array}$ & $\begin{array}{l}20.75 \\
(2.69)\end{array}$ & $\begin{array}{l}8.21 \\
(1)\end{array}$ & $\begin{array}{l}5.08 \\
(0.87)\end{array}$ \\
\hline $10 \%$ & 6 & $\begin{array}{l}33.04 \\
(11.5)\end{array}$ & $\begin{array}{l}79.48 \\
(8.11)\end{array}$ & $\begin{array}{l}49.32 \\
(7.84)\end{array}$ & $\begin{array}{l}17.78 \\
(2.31)\end{array}$ & $\begin{array}{l}7.14 \\
(1.9)\end{array}$ & $\begin{array}{l}3.84 \\
(0.82)\end{array}$ \\
\hline $10 \%$ & 12 & $\begin{array}{l}33.87 \\
(6.28)\end{array}$ & $\begin{array}{l}74.87 \\
(6.43)\end{array}$ & $\begin{array}{l}51.38 \\
(2.17)\end{array}$ & $\begin{array}{l}19.19 \\
(1.53)\end{array}$ & $\begin{array}{l}7.04 \\
(1.03)\end{array}$ & $\begin{array}{l}3.76 \\
(0.46)\end{array}$ \\
\hline $25 \%$ & 0 & $\begin{array}{l}37.13 \\
(4.24)\end{array}$ & $\begin{array}{l}78.16 \\
(2.89)\end{array}$ & $\begin{array}{l}51.16 \\
(2)\end{array}$ & $\begin{array}{l}18.84 \\
(1.76)\end{array}$ & $\begin{array}{l}8.26 \\
(1.09)\end{array}$ & $4.84(0.4)$ \\
\hline $25 \%$ & 6 & $\begin{array}{l}37.66 \\
(2.24)\end{array}$ & $\begin{array}{l}78.17 \\
(4.58)\end{array}$ & $\begin{array}{l}49.79 \\
(3.35)\end{array}$ & $\begin{array}{l}19.95 \\
(2.01)\end{array}$ & $\begin{array}{l}8.13 \\
(1.43)\end{array}$ & $\begin{array}{l}3.84 \\
(0.41)\end{array}$ \\
\hline $25 \%$ & 12 & $\begin{array}{l}37.6 \\
(6.86) \\
\end{array}$ & $\begin{array}{l}83.94 \\
(4.93) \\
\end{array}$ & $\begin{array}{l}53.27 \\
(5.81) \\
\end{array}$ & $\begin{array}{l}18.75 \\
(2.48)\end{array}$ & $\begin{array}{l}7.94 \\
(1.46) \\
\end{array}$ & $\begin{array}{l}3.32 \\
(0.67) \\
\end{array}$ \\
\hline \multicolumn{8}{|l|}{ WWTP2 } \\
\hline $10 \%$ & 0 & $\begin{array}{l}38.37 \\
(7.79)\end{array}$ & $\begin{array}{l}77.87 \\
(6.92)\end{array}$ & $\begin{array}{l}49.31 \\
(5.81)\end{array}$ & $\begin{array}{l}18.65 \\
(3.05)\end{array}$ & $\begin{array}{l}7.99 \\
(2.05)\end{array}$ & $\begin{array}{l}5.23 \\
(0.36)\end{array}$ \\
\hline
\end{tabular}




\begin{tabular}{|c|c|c|c|c|c|c|c|}
\hline $10 \%$ & 6 & $\begin{array}{l}37.91 \\
(6.29)\end{array}$ & $\begin{array}{l}82.36 \\
(2.38)\end{array}$ & $\begin{array}{l}52.2 \\
(2.56)\end{array}$ & $\begin{array}{l}19.67 \\
(2.35)\end{array}$ & $\begin{array}{l}8.3 \\
(1.39)\end{array}$ & $\begin{array}{l}3.78 \\
(0.39)\end{array}$ \\
\hline $10 \%$ & 12 & $\begin{array}{l}39.95 \\
(4.18)\end{array}$ & $\begin{array}{l}80.28 \\
(3.98)\end{array}$ & $\begin{array}{l}55.17 \\
(1.74)\end{array}$ & $\begin{array}{l}20.25 \\
(0.96)\end{array}$ & $\begin{array}{l}8.35 \\
(1.17)\end{array}$ & $\begin{array}{l}3.85 \\
(0.52)\end{array}$ \\
\hline $25 \%$ & 0 & $\begin{array}{l}40.13 \\
(6.29)\end{array}$ & $\begin{array}{l}78.61 \\
(8.63)\end{array}$ & $\begin{array}{l}48.75 \\
(3.38)\end{array}$ & $\begin{array}{l}21.16 \\
(2.03)\end{array}$ & $\begin{array}{l}9.29 \\
(2)\end{array}$ & $\begin{array}{l}5.53 \\
(0.52)\end{array}$ \\
\hline $25 \%$ & 6 & $\begin{array}{l}42.78 \\
(7.66)\end{array}$ & $\begin{array}{l}81.62 \\
(4.8)\end{array}$ & $\begin{array}{l}55.27 \\
(4.19)\end{array}$ & $\begin{array}{l}21.97 \\
(1.44)\end{array}$ & $\begin{array}{l}10.25 \\
(3.55)\end{array}$ & $\begin{array}{l}3.85 \\
(0.56)\end{array}$ \\
\hline $25 \%$ & 12 & $\begin{array}{l}33.06 \\
(5.7) \\
\end{array}$ & $\begin{array}{l}77.6 \\
(2.75) \\
\end{array}$ & $\begin{array}{l}49.49 \\
(0.85)\end{array}$ & $\begin{array}{l}19.3 \\
(2.47) \\
\end{array}$ & $\begin{array}{l}6.88 \\
(1.14) \\
\end{array}$ & $\begin{array}{l}3.34 \\
(0.37) \\
\end{array}$ \\
\hline \multicolumn{8}{|c|}{ WWTP2: Grab } \\
\hline $50 \%$ & 0 & $\begin{array}{l}35.45 \\
(9.42)\end{array}$ & $\begin{array}{l}78.75 \\
(8.97)\end{array}$ & $\begin{array}{l}47.26 \\
(2.73)\end{array}$ & $\begin{array}{l}18.14 \\
(1.02)\end{array}$ & $\begin{array}{l}7.35 \\
(2.34)\end{array}$ & $\begin{array}{l}4.97 \\
(0.57)\end{array}$ \\
\hline $50 \%$ & 6 & $\begin{array}{l}40.05 \\
(6.37)\end{array}$ & $\begin{array}{l}81.3 \\
(4.24)\end{array}$ & $\begin{array}{l}56.58 \\
(4.08)\end{array}$ & $\begin{array}{l}19.24 \\
(1.94)\end{array}$ & $\begin{array}{l}8.84 \\
(1.99)\end{array}$ & $\begin{array}{l}3.62 \\
(0.65)\end{array}$ \\
\hline $50 \%$ & 12 & $\begin{array}{l}32.08 \\
(5.5)\end{array}$ & $\begin{array}{l}79.42 \\
(3.39) \\
\end{array}$ & $\begin{array}{l}47.53 \\
(3.28)\end{array}$ & $\begin{array}{l}17.98 \\
(1.38) \\
\end{array}$ & $\begin{array}{l}7.07 \\
(1.5) \\
\end{array}$ & $\begin{array}{l}3.42 \\
(0.52) \\
\end{array}$ \\
\hline
\end{tabular}

Table 3.2 Summary statistics (mean and standard deviation) for change in oyster mass and height from week 0-6 and week 0-12. Oysters were exposed to composite effluent from two treatment plants at $10 \%$ and $25 \%$ concentrations, and $50 \%$ grab effluent from WWTP2. Summaries represent the average of within-tank means of six oysters at week 6 and three oysters at weeks 12 for each treatment ( $n=4$ tanks per treatment).

\begin{tabular}{llll}
\hline Effluent Concentration & Sample Week & Change in mass $(\mathbf{g})$ & Change in height $(\mathbf{m m})$ \\
\hline Control & & & \\
\hline $0 \%$ & 6 & $-1.11(0.28)$ & $0.46(0.31)$ \\
$0 \%$ & 12 & $-0.88(0.09)$ & $1.15(0.45)$ \\
\hline WWTP1 & & & \\
\hline $10 \%$ & 6 & $-1(0.55)$ & $0.77(1.31)$ \\
$10 \%$ & 12 & $-0.81(0.72)$ & $0.9(1.5)$ \\
$25 \%$ & 6 & $-0.94(0.17)$ & $0.41(0.21)$ \\
$25 \%$ & 12 & $-0.9(0.29)$ & $0.56(0.12)$ \\
\hline WWTP2 & & & \\
\hline $10 \%$ & 6 & $-1.16(0.21)$ & $0.25(0.09)$ \\
$10 \%$ & 12 & $-1.18(0.55)$ & $0.36(0.48)$ \\
$25 \%$ & 6 & $-1.26(0.23)$ & $0.63(0.18)$ \\
$25 \%$ & 12 & $-0.8(0.29)$ & $1.08(0.55)$ \\
\hline WWTP2: Grab & & & \\
\hline $50 \%$ & 6 & $-0.91(0.12)$ & $0.53(0.25)$ \\
$50 \%$ & 12 & $-0.63(0.52)$ & $0.76(0.39)$ \\
\hline
\end{tabular}

Table 3.3 Statitistical summary for two-way mixed ANOVA on oyster growth, wet tissue weight, and condition index. Treatment refers to effluent concentration. Significant pvalues $(\mathrm{p}<.05)$ are bolded and marginally significant $\mathrm{p}$-values $(\mathrm{p}<.10)$ are italicized. Wet tissue weight results from WWTP2: Grab are from robust (nonparametric) ANOVA.

\begin{tabular}{lllll}
\hline Dependent Variable & Factor & Df & F & P \\
\hline WWTP1 & & & & \\
\hline Change in Mass & Treatment & 2 & 0.058 & 0.944 \\
& Sample Week & 1 & 3.993 & 0.077 \\
\hline
\end{tabular}




\begin{tabular}{|c|c|c|c|c|}
\hline & Treatment*Sample Week & 2 & 0.523 & 0.609 \\
\hline \multirow[t]{3}{*}{ Change in shell height } & Treatment & 2 & 0.216 & 0.810 \\
\hline & Sample Week & 1 & 17.434 & 0.002 \\
\hline & Treatment*Sample Week & 2 & 5.375 & 0.029 \\
\hline \multirow[t]{3}{*}{ Wet tissue weight } & Treatment & 2 & 0.897 & 0.441 \\
\hline & Sample Week & 2 & 1.194 & 0.326 \\
\hline & Treatment*Sample Week & 4 & 0.991 & 0.437 \\
\hline \multirow[t]{3}{*}{ Condtion Index } & Treatment & 2 & 0.877 & 0.449 \\
\hline & Sample Week & 2 & 11.578 & 0.00059 \\
\hline & Treatment*Sample Week & 4 & 0.098 & 0.982 \\
\hline \multicolumn{5}{|l|}{ WWTP2 } \\
\hline \multirow{3}{*}{ Change in Mass } & Treatment & 2 & 0.516 & 0.614 \\
\hline & Sample Week & 1 & 4.942 & 0.053 \\
\hline & Treatment*Sample Week & 2 & 1.792 & 0.221 \\
\hline \multirow[t]{3}{*}{ Change in shell height } & Treatment & 2 & 3.633 & 0.070 \\
\hline & Sample Week & 1 & 11.640 & 0.008 \\
\hline & Treatment*Sample Week & 2 & 1.896 & 0.205 \\
\hline \multirow[t]{3}{*}{ Wet tissue weight } & Treatment & 2 & 0.467 & 0.641 \\
\hline & Sample Week & 2 & 2.727 & 0.092 \\
\hline & Treatment*Sample Week & 4 & 1.213 & 0.340 \\
\hline \multirow{3}{*}{ Condtion Index } & Treatment & 2 & 0.020 & 0.980 \\
\hline & Sample Week & 2 & 27.409 & 0.000003 \\
\hline & Treatment*Sample Week & 4 & 0.888 & 0.491 \\
\hline \multicolumn{5}{|l|}{ WWTP2: Grab } \\
\hline \multirow[t]{3}{*}{ Change in Mass } & Treatment & 1 & 1.759 & 0.233 \\
\hline & Sample Week & 1 & 3.773 & 0.100 \\
\hline & Treatment*Sample Week & 1 & 0.040 & 0.849 \\
\hline \multirow[t]{3}{*}{ Change in shell height } & Treatment & 1 & 0.542 & 0.489 \\
\hline & Sample Week & 1 & 13.304 & 0.011 \\
\hline & Treatment*Sample Week & 1 & 3.474 & 0.112 \\
\hline \multirow[t]{3}{*}{ Wet tissue weight } & Treatment & 1 & 0.2640 & 0.634 \\
\hline & Sample Week & 2 & 1.935 & 0.259 \\
\hline & Treatment*Sample Week & 2 & 0.043 & 0.959 \\
\hline \multirow[t]{3}{*}{ Condtion Index } & Treatment & 1 & 1.113 & 0.332 \\
\hline & Sample Week & 2 & 9.371 & 0.004 \\
\hline & Treatment*Sample Week & 2 & 0.128 & 0.881 \\
\hline
\end{tabular}

Table 3.4 Statistical summary for one-way ANOVA and t-tests on oyster feeding rate at each sampling week among treatments (control, 10\%, 25\%, 50\% (grab) effluent).

Analysis was performed separately for each WWTP.

\begin{tabular}{llllll}
\hline & Sample Week & Analysis & Df & F/T & P \\
\hline WWTP1 & $\mathbf{6}$ & ANOVA & $\mathbf{2}$ & $\mathbf{1 0 . 2 6 9}$ & $\mathbf{0 . 0 1 2}$ \\
& 7 & ANOVA & 2 & 1.545 & 0.288 \\
WWTP2 & 12 & ANOVA & 2 & 0.274 & 0.770 \\
& 6 & ANOVA & 2 & 1.088 & 0.395 \\
& 7 & ANOVA & 2 & 0.120 & 0.889 \\
WWTP2: Grab & 12 & t-test & 4 & 0.622 & 0.568 \\
& 6 & t-test & 4 & -2.325 & 0.081 \\
& 7 & t-test & 4 & -0.800 & 0.454 \\
& 12 & t-test & 4 & -0.602 & 0.580 \\
\hline
\end{tabular}


WWTP 1

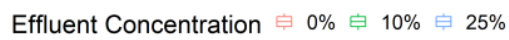

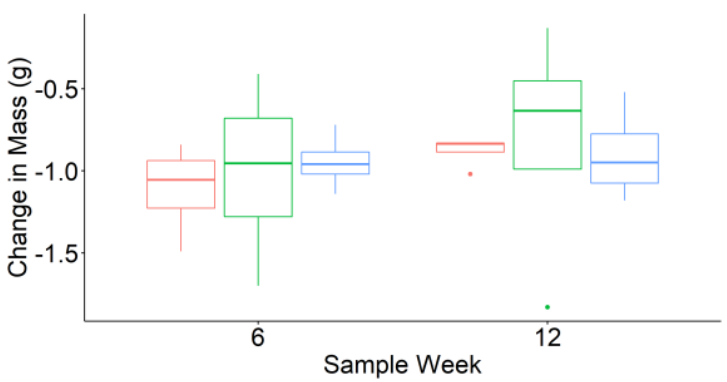

WWTP 2

Effluent Concentration

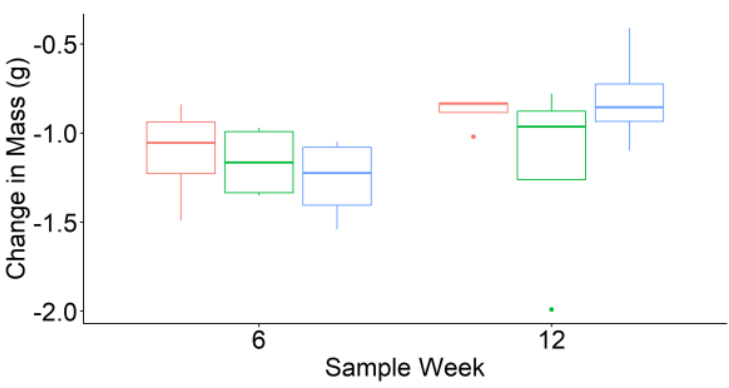

WWTP 2: Grab

Effluent Concentration $0 \%$ 白 $50 \%$

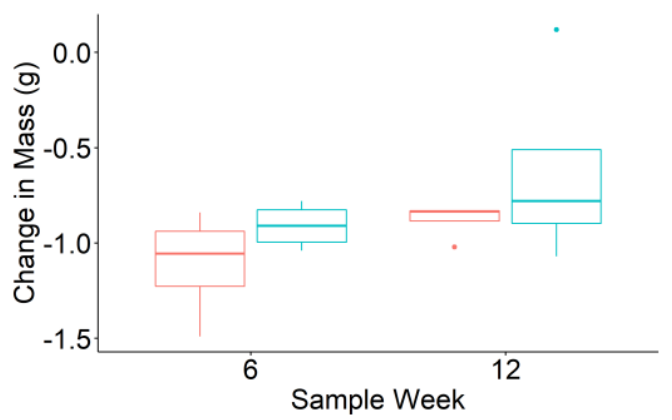

WWTP 1

Effluent Concentration $0 \%$ 追 $10 \%$ 白 $25 \%$

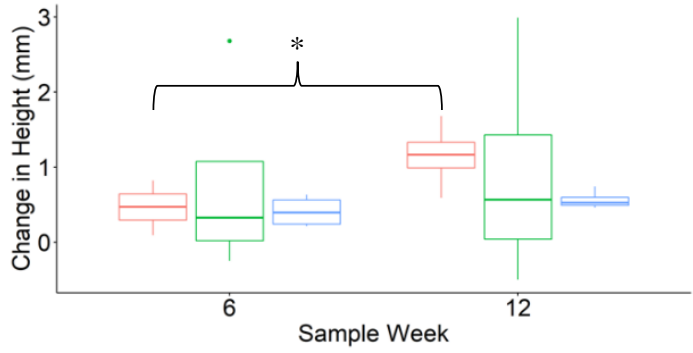

WWTP 2

Effluent Concentration 白 $0 \%$ 白 $10 \%$ 升 $25 \%$

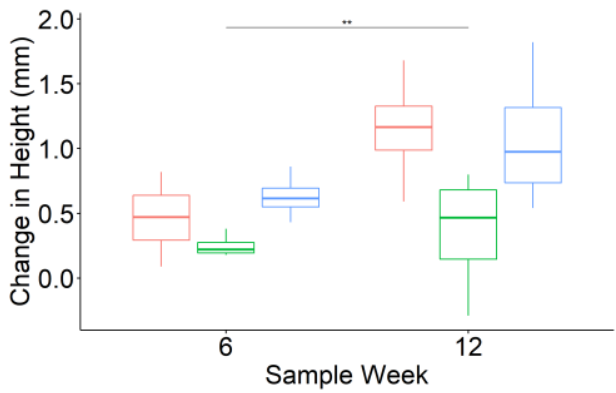

WWTP 2: Grab

Effluent Concentration 官 $0 \%$ 官 $50 \%$

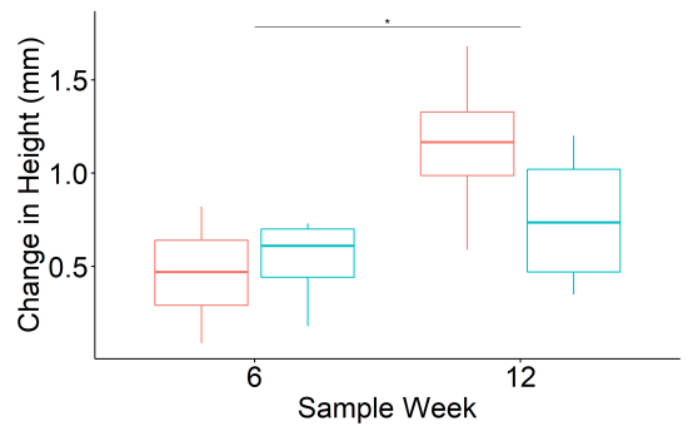

Figure 3.2 Boxplots of change in oyster mass and shell height after exposure to effluent $(10 \%, 25 \%, 50 \%)$ from two wastewater treatment plants and a seawater control $(0 \%)$ from 0-6 weeks and 0-12 weeks. The mean change in growth per tank was calculated for 6 oysters at week 6 and 3 oysters at week 12. Asterisks indicate significant differences $(\mathrm{p}<.05)$ from mixed ANOVA. 
WWTP 1

Effluent Concentration $0 \%$ 白 $10 \%$ 追 $25 \%$

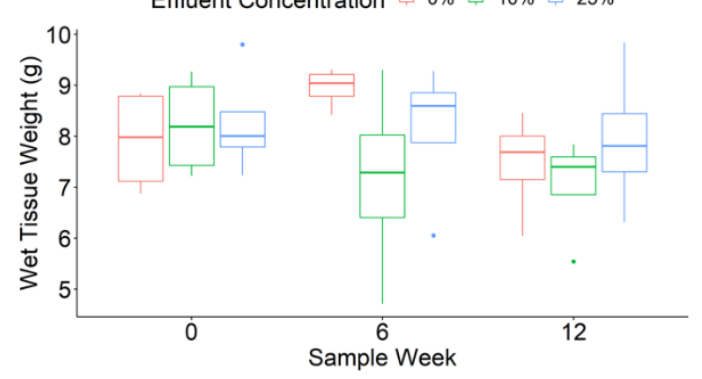

WWTP 2

Effluent Concentration $0 \%$ 白 $10 \%$ 白 $25 \%$

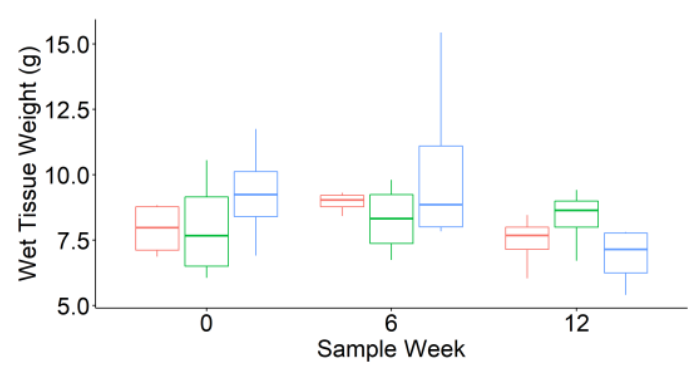

WWTP 2: Grab

Effluent Concentration $0 \%$ 官 $50 \%$

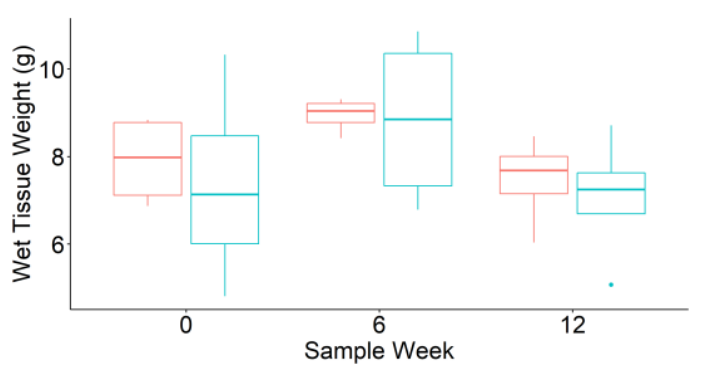

WWTP 1

Effluent Concentration $0 \%$ 追 $10 \%$ 官 $25 \%$

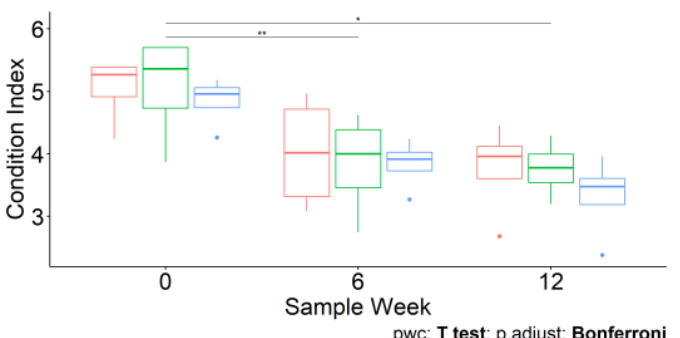

WWTP 2

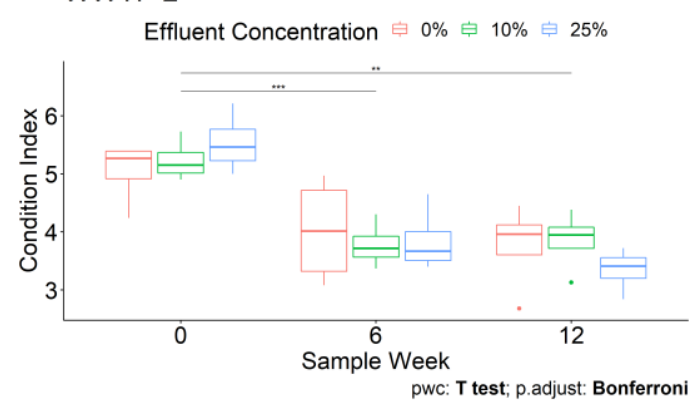

WWTP 2: Grab Effluent

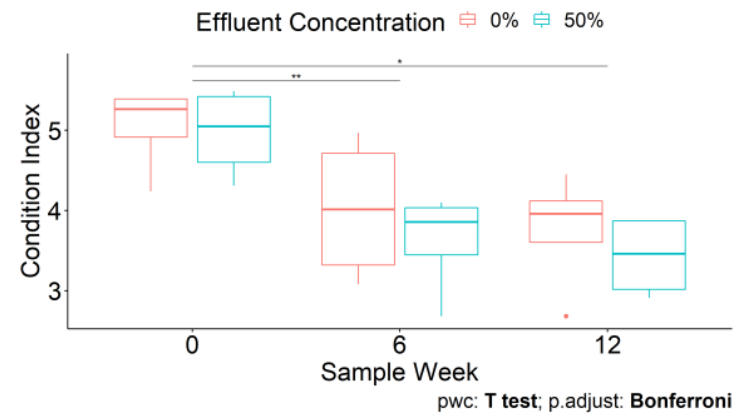

Figure 3.3 Boxplots of oyster wet tissue weight and condition index after exposure to effluent from two wastewater treatment plants and a seawater control (0\%), sampled at three time points $(0,6$, and 12 weeks). Significant differences in oyster condition at sample weeks are indicated by asterisks. No significant differences were observed based on treatment $(\mathrm{p}>.05)$. 
WWTP 1

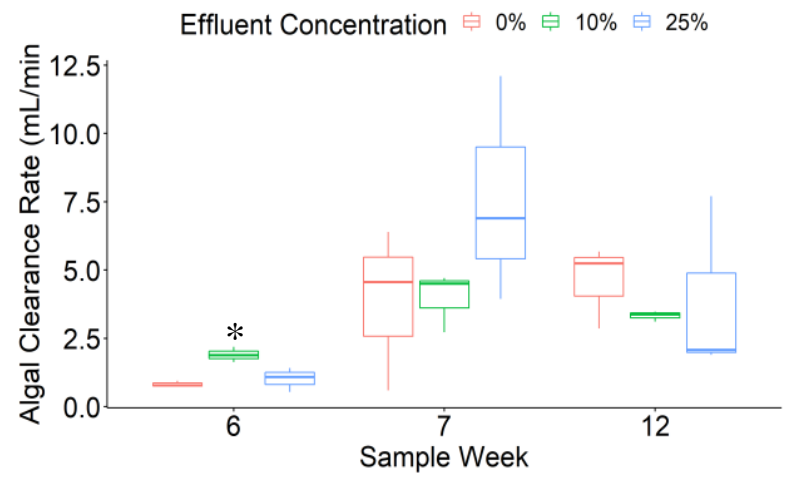

WWTP 2

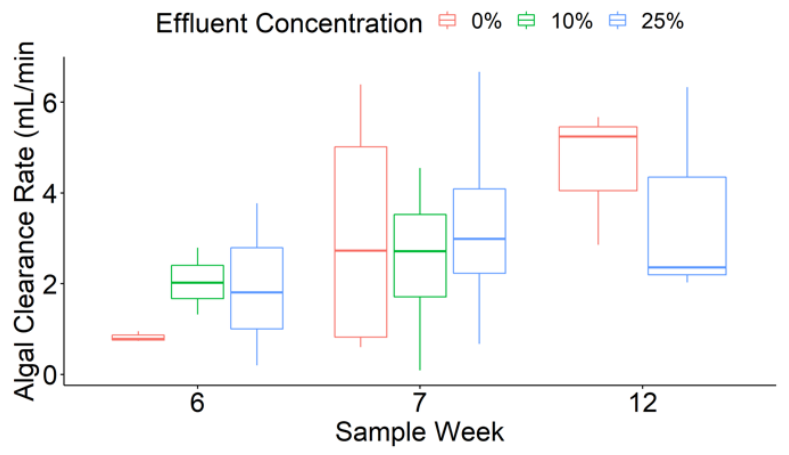

WWTP 2: Grab

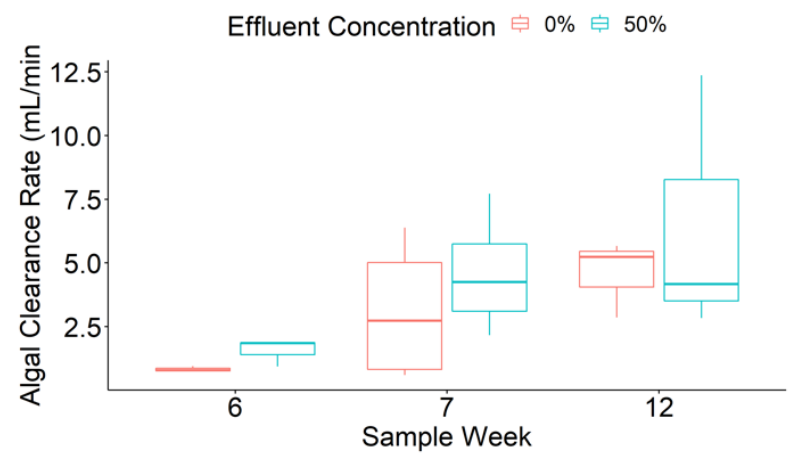

Figure 3.4 Boxplots of oyster feeding rates (measured as algal clearance) after exposure to effluent from two wastewater treatment plants and a seawater control (0\%), sampled at three time points $(6,7$ and 12 weeks). A significant difference in feeding rate during week 6 in WWTP1 is indicated by an asterisk (One-way ANOVA: $\mathrm{p}=.01$ ). 


\subsubsection{PPCPs in Effluent and Tissue}

In the effluent, 30 of the 58 analyzed PPCPs and their metabolites were detected, with 27 compounds detected in each WWTP (Table 3.5). Miconazole, roxithromycin, and sulfamethazine were detected in WWTP1, but not WWTP2 effluent. Caffeine, dehydronifedipine, and glyburide were detected in WWTP2, but not WWTP1 effluent. Concentrations ranged from $0.734-1869 \mathrm{ng} / \mathrm{L}$ with roxithromycin, glyburide, and miconazole having the lowest concentrations and hydrochlorothiazide, furosemide, and 2-Hydroxy-ibuprofen having the highest concentrations (Table 3.5). The total combined concentrations of PPCPs in the two treatment plants were similar, with a mean and standard deviation of 239 (409) for WWTP1 and 241 (351) for WWTP2. A t-test on log transformed data revealed no significant difference in concentration between the two WWTPs (t-test: $t_{58}=-0.46, p=.64$ ). Three of the four analyzed alkylphenols were detected in effluent with 4-NP and 4-NP2EO in both treatment plants, and 4-NP1EO only in WWTP1 (Table 3.5). Nonylphenol was found at the highest concentrations with 197 and 166 ng/L in WWTP1 and WWTP2, respectively. Both nonylphenol ethoxylates had concentrations less than two times the lab blank. We detected a total of 13 PPCPs in oyster tissues, with 12 PPCPs in WWTP1 oysters and 11 PPCPs in WWTP2 oysters (Table 3.6). Six PPCPs were detected in every sample, regardless of WWTP (carbamazepine, diphenhydramine, diltiazam, fluoxetine, thiabendazole, trimethoprim) and diphenhydramine had the highest concentrations overall. Triclocarban and 2hydroxy-ibuprofen were detected in WWTP1, but not in WWT2 exposed oysters. Clarithromycin was detected in WWTP2, but not WWTP1 exposed oysters. Control 
oysters had few detections in comparison to wastewater exposed oysters, with only three PPCPs found (2-Hydroxy-ibuprofen, sulfamethoxazole, thiabendazole). With the exception of 2-Hydroxy-ibuprofen, control concentrations were just above the detection limit. Four alkylphenols (NP1EO, NP2EO, 4-NP, 4n-OP) were detected in oysters exposed to both treatments and the controls. Three alkylphenols (NP1EO, NP2EO, 4-NP) were detected in lab blanks above the reporting limit, with the lab blank concentraions for 4-NP higher than all sample detections. Therefore, most of the tissue alkylphenol concentrations were lower than or very close to the lab blank. All of the compounds detected in oyster tissues were found in the effluent except for 4n-OP. Bioaccumulation factors ranged from 0.03 to 10.8 with 4-NP2EO, 4-NP, and fluoxetine having the highest values.

Table 3.5 Concentrations of PPCPs and alkylphenols detected in composite wastewater treatment plant effluent. Each sample is a composite of approximately $100 \mathrm{~mL}$ from each weekly 24-hour composite sample from each treatment plant. Concentrations are reported in nanograms per liter $(\mathrm{ng} / \mathrm{L})$ with higher concentration of each analyte among the two WWTPs bolded. $\log \mathrm{K}_{\mathrm{ow}}$ values calculated using XLogP3 were obtained from PubChem. Concentration ranges in single samples of effluent from Meador et al. (2016) are included for comparison. Reporting limit for each compound is reported in parentheses. Codes: $\mathrm{ND}=$ not detected; $\wedge=$ less than $2 \mathrm{x}$ lab blank or reporting limit; $\mathrm{NF}=$ not found.

\begin{tabular}{|c|c|c|c|c|c|}
\hline Analyte & Use & $\begin{array}{l}\log \\
K_{\text {ow }}\end{array}$ & WWTP1 & WWTP2 & $\begin{array}{l}\text { Meador et } \\
\text { al. (2016) }\end{array}$ \\
\hline \multicolumn{6}{|l|}{ PPCPs } \\
\hline Azithromycin & Antibiotic & 4.0 & $500(2.76)$ & 344 (1.69) & $261-629$ \\
\hline Bisphenol A & Product additive & 3.3 & $25.8^{\wedge}(13.4)$ & $13.3^{\wedge}(7.00)$ & $350-4290$ \\
\hline Caffeine & Stimulant & -0.1 & ND & $115(14.7)$ & $152-1170$ \\
\hline Carbamazepine & Anticonvulsant & 2.5 & $732(1.48)$ & $253(1.47)$ & $510-735$ \\
\hline Ciprofloxacin & Antibiotic & -1.1 & $43.2(12.9)$ & $113(8.93)$ & 158-192 \\
\hline Clarithromycin & Antibiotic & 3.16 & $69.2(1.48)$ & $111(1.47)$ & $52-181$ \\
\hline Dehydronifedipine & $\begin{array}{l}\text { Drug metabolite } \\
\text { (nifedipine) }\end{array}$ & 2.8 & ND & $2.62(0.589)$ & $13-15$ \\
\hline 1,7-Dimethylxanthine & $\begin{array}{l}\text { Drug metabolite } \\
\text { (caffeine) }\end{array}$ & NF & $114^{\wedge}(59.1)$ & $270(58.9)$ & $873-2060$ \\
\hline Diphenhydramine & Antihistamine & 3.3 & $280(0.591)$ & $554(0.589)$ & $1030-1240$ \\
\hline Diltiazem & Antihypertensive & 3.1 & $79.1(0.296)$ & $78.8(0.437)$ & $390-425$ \\
\hline Erythromycin- $\mathrm{H}_{2} \mathrm{O}$ & Antibiotic & 2.7 & $11(2.27)$ & $75.6(2.26)$ & $87-138$ \\
\hline
\end{tabular}




\begin{tabular}{|c|c|c|c|c|c|}
\hline Fluoxetine & Antidepressant & 4.0 & $49.6(4.44)$ & $24.9(1.47)$ & $57-60$ \\
\hline Furosemide & Diuretic & 2.0 & $939(3.94)$ & $453(3.93)$ & $994-1290$ \\
\hline Gemfibrozil & Lipid-regulator & 3.8 & $254(0.788)$ & 314 (0.785) & $1360-1640$ \\
\hline Glipizide & Antidiabetic & 1.9 & $6.04(0.788)$ & $3.35(0.785)$ & $22-23$ \\
\hline Glyburide & Antidiabetic & 4.8 & $\mathrm{ND}$ & $\begin{array}{l}1.54^{\wedge} \\
(0.785)\end{array}$ & $7.1-11$ \\
\hline Hydrochlorothiazide & Diuretic & -0.1 & $1860(8.67)$ & $1750(8.64)$ & $411-578$ \\
\hline 2-Hydroxy-ibuprofen & $\begin{array}{l}\text { Drug metabolite } \\
\text { (ibuprofen) }\end{array}$ & 2.1 & $620(6.66)$ & $471(7.24)$ & $1160-4550$ \\
\hline Ibuprofen & $\begin{array}{l}\text { Non-steroidal anti- } \\
\text { inflammatory drug }\end{array}$ & 3.5 & $167(3.94)$ & 227 (3.93) & $116-1060$ \\
\hline Miconazole & Antifungal & 5.3 & $1.79^{\wedge}(1.48)$ & ND & 4.9 \\
\hline Naproxen & $\begin{array}{l}\text { Non-steroidal anti- } \\
\text { inflammatory drug }\end{array}$ & 3.3 & $79.5(3.40)$ & $220(2.66)$ & $106-701$ \\
\hline Ofloxacin & Antibiotic & -0.4 & $14.5(3.44)$ & $85.6(2.52)$ & $108-387$ \\
\hline Roxithromycin & Antibiotic & 3.1 & $\begin{array}{l}0.734^{\wedge} \\
(0.640)\end{array}$ & ND & 3.8 \\
\hline Sulfamethazine & Antibiotic & 0.3 & $8.22(3.32)$ & ND & ND \\
\hline Sulfamethoxazole & Antibiotic & 0.9 & $408(2.33)$ & $493(1.88)$ & 1380 \\
\hline Thiabendazole & Antihelmintic & 2.5 & $16.8(16.8)$ & $18.2(1.47)$ & $24-27$ \\
\hline Triclocarban & Antimicrobial & 5.3 & $4.75(0.394)$ & $2.57(0.393)$ & $12-17$ \\
\hline Triclosan & Antimicrobial & 5.0 & $98.1(5.91)$ & $30.5(5.89)$ & $250-538$ \\
\hline Trimethoprim & Antibiotic & 0.9 & $59.6(2.09)$ & $461(2.33)$ & $742-852$ \\
\hline $\begin{array}{l}\text { Warfarin } \\
\text { Alkylphenols }\end{array}$ & Anticoagulant & 2.7 & $7.66(0.394)$ & $9.2(0.393)$ & 6.2 \\
\hline 4-NP1EO & Surfactant & 5.8 & $36^{\wedge}(7.85)$ & ND (8.68) & $1220-1760$ \\
\hline 4-NP2EO & Surfactant & 5.6 & $16.6^{\wedge}(6.23)$ & $19.7^{\wedge}(3.44)$ & $1690-2610$ \\
\hline 4-NP & Surfactant metabolite & 5.9 & $197(5.43)$ & $162(2.38)$ & 162 \\
\hline
\end{tabular}

Table 3.6 Concentrations of pharmaceuticals and alkylphenols detected in freeze-dried oyster tissues from controls and $25 \%$ effluent exposures from both treatment plants after 12 weeks of exposure. Each sample is a composite of three half oysters from one tank that were homogenized prior to splitting. Concentrations reported in nanograms/gram wet weight (ng/g ww). Reporting limit (RL) for each compound is reported in parentheses.

Bioaccumulation factors (BAF) provided for compounds also detected in effluent. Codes: $\mathrm{ND}=$ not detected; ${ }^{\wedge}=$ less than $2 \mathrm{x}$ lab blank or reporting limit; *=less than lab blank.

\begin{tabular}{lllllllll}
\hline Analyte & \multicolumn{2}{l}{ WWTP1 25\% $(\mathbf{n = 3})$} & \multicolumn{2}{c}{ WWTP2 25\% (n=3) } & \multicolumn{2}{c}{ Control (n=2) } \\
& Tank 1 & Tank 2 & Tank 3 & Tank 1 & Tank 2 & Tank 3 & Tank 1 & Tank 2 \\
\hline PPCPs & & & & & & & & \\
\hline Azithromycin & 4.72 & 4.62 & 3.91 & ND & 3.60 & 3.01 & ND & ND \\
$\quad$ RL & $(1.98)$ & $(1.61)$ & $(2.17)$ & & $(1.46)$ & $(1.51)$ & & \\
BAF & 0.04 & 0.04 & 0.03 & & 0.04 & 0.04 & & \\
Carbamazepine & 10.8 & 14.0 & 12.9 & $4.23^{\wedge}$ & 7.63 & 6.39 & ND & ND \\
$\quad$ RL & $(1.30)$ & $(1.61)$ & $(1.45)$ & $(2.59)$ & $(1.46)$ & $(1.51)$ & & \\
BAF & 0.06 & 0.08 & 0.07 & 0.07 & 0.13 & 0.11 & & \\
Clarithromycin & ND & ND & ND & ND & $2.08^{\wedge}$ & ND & ND & ND \\
$\quad$ RL & & & & & $(1.46)$ & & & \\
BAF & & & & & 0.07 & & & \\
Diphenhydramine & 40.0 & 44.9 & 26.4 & 79.6 & 44.2 & 43.0 & ND & ND \\
\hline
\end{tabular}




\begin{tabular}{|c|c|c|c|c|c|c|c|c|}
\hline RL & $(0.521)$ & $(0.659)$ & $(0.581)$ & (1.03) & $(0.584)$ & $(0.602)$ & & \\
\hline BAF & 0.57 & 0.64 & 0.38 & 0.57 & 0.32 & 0.31 & & \\
\hline Diltiazem & 6.26 & 11.2 & 3.14 & 8.56 & 8.73 & 4.85 & ND & ND \\
\hline RL & $(0.520)$ & $(0.732)$ & $(0.775)$ & $(0.967)$ & $(0.425)$ & $(0.552)$ & & \\
\hline BAF & 0.32 & 0.57 & 0.16 & 0.43 & 0.44 & 0.25 & & \\
\hline Fluoxetine & 14.0 & 28.7 & 9.57 & 50.9 & 24.1 & 12.7 & ND & ND \\
\hline RL & $(4.16)$ & $(1.61)$ & $(1.45)$ & (2.59) & $(1.46)$ & $(1.51)$ & & \\
\hline BAF & 1.13 & 2.31 & 0.77 & 8.18 & 3.87 & 2.04 & & \\
\hline Gemfibrozil & $2.27^{\wedge}$ & ND & ND & ND & $2.45^{\wedge}$ & ND & ND & ND \\
\hline RL & (2.08) & & & & $(2.33)$ & & & \\
\hline BAF & 0.04 & & & & 0.03 & & & \\
\hline 2-Hydroxy- & $14.2^{\wedge}$ & ND & ND & ND & ND & ND & $12.8^{\wedge}$ & 20.7 \\
\hline RL & $(10.4)$ & & & & & & (11.1) & (7.91) \\
\hline BAF & 0.09 & & & & & & & \\
\hline Ofloxacin & $1.89^{*}$ & $2.4^{\wedge}$ & ND & 5.21 & ND & ND & ND & ND \\
\hline RL & $(1.72)$ & $(1.61)$ & & $(2.59)$ & & & & \\
\hline BAF & 0.52 & 0.66 & & 0.24 & & & & \\
\hline Sulfamethoxazole & $9.97^{\wedge}$ & ND & ND & ND & 2.37 & ND & $4.65^{\wedge}$ & ND \\
\hline RL & $(7.90)$ & & & & (1.07) & & (2.51) & \\
\hline BAF & 0.10 & & & & 0.02 & & & \\
\hline Thiabendazole & 14.1 & 21.4 & 19.1 & 31.9 & 16.7 & 10.8 & $1.40 *$ & ND \\
\hline RL & $(1.30)$ & $(1.61)$ & $(1.61)$ & (2.59) & $(1.46)$ & $(1.51)$ & $(1.39)$ & \\
\hline BAF & 3.36 & 5.10 & 4.55 & 7.01 & 3.67 & 2.37 & & \\
\hline Triclocarban & 3.50 & 3.20 & $1.91^{\wedge}$ & ND & ND & ND & ND & ND \\
\hline RL & $(1.04)$ & $(1.29)$ & (1.16) & & & & & \\
\hline BAF & 2.95 & 2.69 & 1.61 & & & & & \\
\hline Trimethoprim & 3.92 & $2.37^{\wedge}$ & $2.35^{\wedge}$ & 27.9 & 23.3 & 18.3 & ND & ND \\
\hline RL & $(1.30)$ & (1.61) & $(1.45)$ & $(2.59)$ & $(1.46)$ & $(1.51)$ & & \\
\hline BAF & 0.26 & 0.16 & 0.16 & 0.24 & 0.20 & 0.16 & & \\
\hline \multicolumn{9}{|l|}{ Alkylphenols } \\
\hline NP1EO & $8.51^{\wedge}$ & 17.7 & $4.80 *$ & $6.20 *$ & $9.69^{\wedge}$ & ND & $11.2^{\wedge}$ & $2.97 *$ \\
\hline RL & $(3.62)$ & $(2.76)$ & $(2.61)$ & $(4.22)$ & $(2.00)$ & & $(3.00)$ & (1.56) \\
\hline BAF & 0.95 & 1.97 & 0.53 & & & & & \\
\hline NP2EO & $4.75^{\wedge}$ & 44.8 & $5.12^{\wedge}$ & 7.48 & 13.2 & 17.6 & 13.9 & $4.79^{\wedge}$ \\
\hline RL & (1.64) & $(2.27)$ & $(1.85)$ & $(3.85)$ & $(2.00)$ & $(2.08)$ & $(1.79)$ & $(1.33)$ \\
\hline BAF & 1.14 & 10.80 & 1.23 & 1.52 & 2.68 & 3.57 & & \\
\hline 4-NP & $159^{*}$ & $451 *$ & $203 *$ & $264 *$ & $291 *$ & $201 *$ & $211 *$ & $151 *$ \\
\hline RL & (1.64) & $(2.27)$ & (1.85) & $(3.85)$ & $(2.00)$ & $(2.08)$ & $(1.79)$ & (1.33) \\
\hline BAF & 3.23 & 9.16 & 4.12 & 6.52 & 7.19 & 4.96 & & \\
\hline $4 n-O P$ & $16.7^{\wedge}$ & $8.65 *$ & $18.8^{\wedge}$ & $16.1^{\wedge}$ & $5.13 *$ & $11.7^{\wedge}$ & $15.4^{\wedge}$ & $9.97^{\wedge}$ \\
\hline RL & (1.64) & $(2.27)$ & $(2.02)$ & $(3.85)$ & $(2.00)$ & $(2.08)$ & (1.79) & (1.33) \\
\hline
\end{tabular}

Table 3.7 Results of power analysis for each variable from WWTP1 and WWTP2 based on three treatments $(0 \%, 10 \%$, and $25 \%$ effluent). Analysis was based on one-way ANOVA for the week 12 sample measurements. Cohen's f was used to calculate effect size from the results of the experiment.

\begin{tabular}{llll}
\hline Response Variable & $\begin{array}{l}\text { One-way ANOVA } \\
\text { Results }\end{array}$ & Cohen's f & $\begin{array}{l}\text { Recommended } \\
\text { Sample Size }\end{array}$ \\
\hline
\end{tabular}




\begin{tabular}{llll}
\hline WWTP1 & & & \\
\hline Change in mass & $\mathrm{F}_{2,9}=0.05, \mathrm{p}=0.96$ & 0.10 & 322 \\
Change in height & $\mathrm{F}_{2,9}=0.42, \mathrm{p}=0.66$ & 0.30 & 37 \\
Wet tissue weight & $\mathrm{F}_{2,9}=0.57, \mathrm{p}=0.59$ & 0.35 & 27 \\
Condition Index & $\mathrm{F}_{2,9}=0.62, \mathrm{p}=0.56$ & 0.37 & 24 \\
Algal Clearance Rate* & $\mathrm{F}_{2,6}=10.27, \mathrm{p}=0.01$ & 1.86 & 2 \\
\hline WWTP2 & & & \\
\hline Change in mass & $\mathrm{F}_{2,9}=1.16, \mathrm{p}=0.36$ & 0.51 & 13 \\
Change in height & $\mathrm{F}_{2,0}=3.09, \mathrm{p}=.095$ & 0.83 & 6 \\
Wet tissue weight & $\mathrm{F}_{2,9}=1.77, \mathrm{p}=0.22$ & 0.63 & 9 \\
Condition Index & $\mathrm{F}_{2,9}=0.88, \mathrm{p}=0.44$ & 0.44 & 17 \\
Algal Clearance Rate* & $\mathrm{F}_{2,6}=1.09, \mathrm{p}=.40$ & 0.60 & 10 \\
\hline
\end{tabular}

\subsection{Discussion}

Experimental exposure to environmentally relevant concentrations of wastewater effluent had a significant effect on oyster shell growth. Control oysters experienced more shell growth than those exposed to effluent from WWTP1, indicating that effluent suppressed shell growth. This effect was not evident in WWTP2, where all treatments experienced significant shell growth. The pattern here could be due to presence of other harmful compounds that we didn't test for in WWTP1 effluent or presence of two antibiotics in WWTP1 effluent that were not in WWTP2 effluent. In both treatment plants, oysters in the $10 \%$ treatment experienced marginally less shell growth than those in the $25 \%$ treatment. These patterns demonstrate that lower effluent concentrations may affect shell growth more than higher concentrations, emphasizing the importance of including lower concentrations in toxicological studies. Other lab experiments with contaminants of emerging concern have observed non-monotonic responses, where the measured effect does not increase with concentration, including two compounds detected in effluent in the present study (4-NP and BPA) (Fagin 2012). Condition index decreased over time from week 0 to 6 , and then remained steady through week 12 , and was not 
affected by treatment. Oysters lost weight from week 0 to 6 , and then recovered slightly from week 6-12, never reaching their original weight. It is important to note that the amount of shell height growth was low overall (max of $6 \mathrm{~mm}$ ) and condition index and mass decreased over time in all treatments, indicating that all oysters, including controls, were likely experiencing stress and possibly food limitation. This may be attributed to tank conditions or food availability. Though the age of the oysters is unknown, their height range (52-119 mm) indicates that many were below market size of 4-6 inches (101-152 mm) (Galtsoff 1964). In good conditions, Pacific oysters continue to grow regardless of age or size (Galtsoff 1964), yet low incidence of mortality indicates that tank conditions were sufficient for survival, though apparently not optimal for growth or oyster health. Smaller tank environments are more difficult to keep stable and healthy for longer periods of time and though we performed frequent water changes, there may have been inadequate space and replenishment of clean water. Two other lab experiments involving this species reported lack of shell growth with low food quality and quantity being possible reasons (Di Poi et al. 2016; Mottier et al. 2015). In both studies, they fed oysters one species of cultured algae, Isochrysis galbana (T-Iso clone), and claimed that this may only be sufficient for oyster spat, and not nutritive enough for adults. In the present study, oysters were fed "Shellfish Diet 1800," which consists of five marine microalgal species and has been shown to provide proper nutrition in oyster rearing (Reed Mariculture n.d.). Therefore, it is unlikely that food quality was poor but possible that improper mixing in the small tanks led to insufficient food availability preventing adequate feeding. Effects of this ambient stress on oyster fitness may have overshadowed 
impacts of effluent exposure, and reduced the ability to detect significant results. Additionally, results of the power analysis indicate that the lack of effects observed for many responses may also be due to low sample size, rather than effluent having no effects on oysters at these concentrations.

With the exception of one incidence, we did not detect a significant change in oyster feeding rate after exposure to wastewater effluent. There was a higher feeding rate in the $10 \%$ exposure than in the control and 25\% treatment from WWTP1 (Figure 3.4), though the pattern was not evident in WWTP2 exposures and diminished in the next sampling trial (week 7). Feeding rate data were noisy and inconsistent and therefore should be interpreted with caution. These errors are likely due to poor mixing in the tanks from using small, slow flowing filters and potentially inaccurate cell counts from the Coulter counter. The filters we employed were designed for the tank size used (2.5 gallons), but did not provide sufficient flow for proper mixing, which is important for both food delivery to study organisms and algal cell count (Gray and Langdon 2018). It is advised that future studies consider tank mixing when designing feeding rate trials.

Previous studies have reported similar outcomes in lab experiments where Pacific oysters were exposed to anthropogenic contaminants and experienced a lack of effects ranging from cellular to organism levels. Revel et al. (2020) exposed oysters to three concentrations of microplastics with no significant effects on a range of physiological factors, including feeding rate, condition index, oxidative stress, tissue alteration, and DNA damage. A study that exposed Pacific oysters to three concentrations of fluoxetine (anti-depressant) found some significant responses, but overall concluded that fluoxetine 
had minimal effects on physiological functions of oysters at environmentally relevant concentrations (Di Poi et al. 2016). Adult oysters can survive a wide range of environmental conditions (Pauley et al. 1988) and therefore may be more resistant to stressors- including chemical stressors - than other organisms. There is evidence of this at the cellular level whereby a study that compared cellular level biomarker responses to beta-blocking pharmaceuticals determined oysters were less sensitive than clams in measured biomarkers (Khan et al. 2018).

It is possible that effects occurred at biological levels - such as molecular, cellular, and tissue - not measured in this experiment. Two experiments that measured Pacific oyster responses to environmentally relevant concentrations of herbicides at multiple biological levels only identified effects at levels below the whole organism (Akcha et al. 2016; Mottier et al. 2015). Mottier et al. (2015) exposed oysters to three concentrations of glyphosate for 56 days and found no significant differences in organism level responses (condition index, growth, and reproduction). Yet, a few significant responses were identified at the molecular level (gene expression). Similarly, Akcha et al. (2016) measured molecular, cellular, and tissue responses to diuron after 7 days and reported significant effects at molecular (e.g., gene expression) and cellular levels, but no effects at the tissue level (e.g., gametogenesis course, sex ratio, reproductive effort). Several recent studies that only measured effects of contaminants on oysters at lower biological levels (molecular, cellular, tissues) consistently identified effects (e.g., Serrano et al. 2015; Park et al. 2016; Bebianno et al. 2017; Khan et al. 2018). All of these studies had short exposure durations (1-7 days) which may not allow for detecting changes at the 
organismal level, but demonstrate that oysters may, indeed, be susceptible to pollution with detectable effects at molecular, cellular and tissue levels. Unfortunately, it is challenging to interpret the implications of these effects for organism, population, and ecosystem level policy and management decisions.

To our knowledge, only two other lab studies have evaluated effects of direct exposure to WWTP effluent on Pacific oysters. Both had one effluent exposure level, lasted 36-48 hours, and detected alterations in gene expression (Flores-Nunes et al. 2015; Medeiros et al. 2008). Due to the short duration and lack of organism level effects measured, it is difficult to compare our results directly. Additionally, two lab experiments have examined effects of effluent on other bivalve species. A study conducted in Spain exposed Manila clams (Ruditapes philippinarum) to five concentrations of effluent ranging from 3.15-50\% (Díaz-Garduño et al. 2018). Effects on cellular biochemical responses were identified in several treatments, including very low concentrations (3.12$12.5 \%$ ) and many of these effects were reduced following tertiary treatment. Another study showed that exposure to urban WWTP effluent for seven days altered metabolism at the molecular level in male marine mussels (Mytilus galloprovincialis) (Dumas et al. 2020). These studies demonstrate that effluent has the potential to significantly affect physiological function in marine bivalves, but these effects are variable, occur at multiple biological levels, and appear to be species and concentration specific. In addition, because effluent constitutes an unknown mixture of compounds, there could be simultaneous synergistic and antagonistic effects, increasing the complexity of interpreting results (e.g., Almeida et al. 2018). More research is needed to examine whole 
effluent toxicity on bivalves using a multiple biomarker approach under environmentally relevant conditions.

We found a broad array of PPCPs in effluent from two coastal WWTPs. PPCP detections and concentrations in effluent were relatively similar among the two treatment plants. With the exception of six compounds (caffeine, dehydronifedipine, glyburide, miconazole, roxithromycin, sulfamethazine), the same PPCPs were detected in effluent from both WWTPs and the average combined concentrations of PPCPs were statistically equivalent. All of these PPCPs have been identified in coastal effluent in previous work (e.g., Hedgespeth et al. 2012; Vidal-Dorsch et al. 2012; Lara-Martín et al. 2014; Meador et al. 2016; Biel-Maeso et al. 2018). Therefore, the similarity in detections and concentrations among the two treatment plants could be due to these compounds being commonly used and thus found in effluent across locations. Also, both treatment plants use the same type of secondary treatment, which would likely result in similar removal rates. Caffeine was only found in WWTP2, but 1,7-dimethylxanthine, a caffeine metabolite, was detected in WWTP1, indicating that caffeine was likely present and may have been broken down more effectively in this treatment plant. The other five unique compounds were found at low concentrations ( $<9 \mathrm{ng} / \mathrm{L})$ which may be due to lower usage within the surrounding population, or different removal efficiencies at each WWTP. Alkylphenols were detected in WWTP effluent, with 4-NP and 4-NP2EO in both WWTPs, and 4-NP1EO in WWTP1 only. Nonylphenol ethoxylates with more polar groups, indicated by the number in the abbreviated name, are more hydrophilic (Priac et 
al. 2017), which could explain the lack of 4-NP1EO in WWTP2. It is also possible that all of the NP1EO in WWTP2 was transformed into 4-NP.

The concentrations reported here in effluent are generally lower than previous studies characterizing PPCPs and alkylphenols in effluent. However, it is important to note that our samples were comprised of a mixture of 24-hour composites collected over 12 weeks, and most studies report single 24-hour composite effluent samples. We compared concentrations to a study in Puget Sound, WA that reported effluent concentrations for all but one of the compounds in the present study (sulfamethazine) (Meador et al. 2016). Of the 33 chemicals detected, 25 were lower than the minimum concentration in Meador et al. (2016). Notably, NP1EO and NP2EO were approximately 30 and 100 times lower in this study, respectively. This is expected given the difference in treatment plant discharge size and surrounding populations for these two studies. The permitted discharge capacity for the WWTP in Puget Sound was $60 \mathrm{mgd}$, compared to $>1-2$ mgd in this study, and Puget Sound is more populated than the Northern OR coast. Five compounds were within the same range, and the pharmaceuticals, hydrochlorothiazide and warfarin, had higher concentrations in our study than Meador et al. (2016). Notably, hydrochlorothiazide was three times higher in the present study. Twenty of the compounds in this study were detected in previous WWTP effluent studies with higher discharge capacities and larger surrounding populations, and as expected, most concentrations reported here are lower, though a few are within the same concentration range (Biel-Maeso et al. 2018; Hedgespeth et al. 2012; Kostich et al. 2014; Lara-Martín et al. 2014; Meador et al. 2016; Vidal-Dorsch et al. 2012). Notably, 
carbamazepine was within the same range and higher in WWTP1 than other studies. This drug is frequently detected in effluent and water due to its hydrophilicity, with reported WWTP removal rates of 18\% (Brose et al. 2019) and 42.3\% (Lara-Martín et al. 2014).

Several PPCPs found in the WWTP effluent were detected in oyster tissues, indicating that oysters accumulated contaminants from the surrounding water. Ten of the 13 detected PPCPs have moderately high $\log \mathrm{K}_{\mathrm{ow}}$ values $(>2)$ which means they are more likely to accumulate in organism tissue. Ofloxacin and sulfamethoxazole, which have log $\mathrm{K}_{\mathrm{ow}}$ values less than one, had few detections and low concentrations. Trimethoprim (log $\left.\mathrm{K}_{\mathrm{ow}}=0.9\right)$ was detected in all wastewater exposed oyster samples, with high concentrations in WWTP2 oysters. This could be explained by the high concentration of this drug in WWTP2 effluent. Overall, oysters exposed to effluent from WWTP1 had more detections than those exposed to WWTP2 effluent, but only by five compounds. This is contrary to the expected pattern since WWTP1 has a lower discharge capacity and serves a smaller population. For most PPCPs, higher tissue concentrations and detection frequency were associated with higher concentrations in the effluent of the corresponding WWTP.

Three PPCPs were detected in one control sample (2-hydroxy-ibuprofen, sulfamethoxazole, thiabendazole) and one of these was detected in the second control sample (2-hydroxy-ibuprofen). Sulfamethoxazole and thiabendazole concentrations were very close to the detection limit, and thiabendazole was lower than the lab blank concentration. However, 2-hydroxy-ibuprofen was well above the detection limit. Several measures were taken to reduce contamination, but it is impossible to completely avoid. 
Additionally, PPCPs can be exhaled onto samples, and have been found in drinking water (Loraine and Pettigrove 2006), thus some could be present in the ambient artificial seawater used in the experiment. Though the source of these PPCPs is unknown, the few detections and low concentrations compared to effluent exposed oysters indicate that contamination and exposure to PPCPs in the controls was minimal.

Four alkylphenols were detected in oyster tissue samples, one of which was not detected in effluent (4n-OP). Of the 32 reported concentrations in tissues, 13 were less than the lab blank, and 12 were less than two times the lab blank or reporting limit, indicating that alkylphenols accumulated in oysters at very low levels. Only NP1EO and NP2EO had concentrations outside of this range, with NP2EO having the most detections in WWTP2 and the highest concentration in WWTP1 exposed oysters. All four alkylphenols were detected in controls and concentrations were similar to wastewater exposed oysters. These compounds are frequently detected in lab blanks and controls because they can be found in common lab equipment and products (Salgueiro-González et al. 2017). For example, alkylphenols are associated with plastics which can be a major source of lab contamination (Salgueiro-González et al. 2017). Given the low concentrations in effluent and the ubiquity of these compounds, it is possible that alkylphenol concentrations in tissues may simply represent lab contamination.

We detected several compounds with documented effects on organisms. Bisphenol A (BPA) and 4-NP are known endocrine disruptors and show evidence of nonmonotonic responses in mammals (Bulayeva and Watson 2004; Jenkins et al. 2011). Previous studies have demonstrated their effects on marine organisms as well. For 
example, BPA and 4-NP negatively affected marine mussel larval development after 48hour exposure to environmentally relevant concentrations (Fabbri et al. 2014). Significant effects were identified for 4-NP at the same concentration we found in effluent (100 $\mathrm{ng} / \mathrm{L}$ ). The antimicrobials triclosan and triclocarban are known as "emerging endocrine disruptors" (Olaniyan et al. 2016; Vimalkumar et al. 2019) and though their use has been widely reduced due to US regulations limiting branding of products containing antimicrobials (Brose et al. 2019), they are still detected in effluent and environmental matrices. Triclosan has been shown to induce lysosomal membrane destabilization, an indicator of cellular stress, in two species of marine mussels (Canesi et al. 2007; Cortez et al. 2012). One of these studies found significant effects at a concentration of $12 \mathrm{ng} / \mathrm{L}$ (Cortez et al. 2012), which is lower than the concentrations found in effluent in this study. Several pharmaceuticals have shown significant negative effects on marine mollusks at environmentally relevant concentrations. The antibiotics sulfamethoxazole and trimethoprim, which are frequently prescribed together, reduced marine microalgal and mussel growth after 12-week exposure (Teixeira 2016; Teixeira and Granek 2017). Similarly, marine mussel growth, reproductive potential, and feeding rate were suppressed by long-term exposure to fluoxetine, an antidepressant (Peters and Granek 2016). Fluoxetine exposure can also lead to foot detachment in marine snails (Fong and Molnar 2013) and induce spawning in clams (Honkoop et al. 1999). The anticonvulsant, carbamazepine, lowered marine mussel gonadosomatic and condition indices after 28 days of exposure (Oliveira et al. 2017). Further effects of pharmaceutical and personal care products on marine organisms have been reviewed by (Fabbri and Franzellitti 2016; 
Mezzelani et al. 2018; Prichard and Granek 2016). In the present study, trimethoprim, fluoxetine, and carbamazepine were detected in every tissue sample exposed to $25 \%$ effluent, with few effects observed. Given these examples in the literature and detections in effluent and tissue in the present study, we hypothesize that there may have been sublethal sub-organismal effects that we did not measure or detect. Additionally, other marine organisms exposed to this concentration of effluent may experience sublethal effects not detected in the oysters studied here.

PPCP and alkylphenol detections in effluent and accumulation by oysters emphasize the need for monitoring, environmental risk assessment, and pollution reduction. In the US, pollutants in waterways are assessed and regulated through the Clean Water Act, using water quality criteria that specify maximum allowed concentrations of contaminants in surface water based on potential effects on wildlife. With the exception of nonylphenol, PPCPs do not yet have set water quality standards (US EPA 2015). In 2008, the US Environmental Protection Agency (EPA) drafted recommendations for developing water quality criteria for contaminants of emerging concern, including PPCPs, but these criteria have yet to be developed (US EPA 2008). In 2007, Oregon passed Senate Bill 737 in an effort to identify and assess persistent pollutants in WWTP effluent. This bill required the development of a priority pollutant list (including some PPCPs), testing of effluent from 52 large municipal wastewater treatment plants, and development of pollution reduction plans for compounds detected above Plan Initiation Levels (Hope et al. 2012). Three pharmaceuticals detected in a majority of Hope et al. (2012) samples (sulfamethoxazole (92\%), carbamazepine (82\%), 
and diphenhydramine (76\%) were found in this study as well. Two PPCPs were included in the Plan Initiation Level list, triclosan and roxithromycin, but the maximum levels were in the ug/L range (OR DEQ personal communication Oct. 2020), higher than concentrations detected in this study. Improvements to wastewater treatment technology are one option for reducing PPCP loadings to the environment, particularly by adding tertiary treatment. Removal efficiencies are $20-60 \%$ higher using tertiary compared to secondary treatment (Rout et al. 2021) and tertiary treatments can reduce overall toxicity of effluent to aquatic organisms (Schlüter-Vorberg et al. 2017). Tertiary treatment is not widely implemented in the US, and is costly, presenting a huge barrier to reducing these pseudo-persistent compounds. Improper disposal of leftover pharmaceuticals by flushing and throwing in the trash can also pollute waterways and there is a need to implement convenient and safe disposal methods to reduce pollution (Ehrhart et al. 2020). Policies that prioritize funding for enhancing wastewater treatment and proper drug disposal, among other interventions, and identification of long-term effects of mixtures are necessary in moving forward and addressing these emerging pollutants in the environment.

There were several practical limitations in this study that affected the design, and potentially the results. Here we explain these limitations and propose an improved experimental design to address some of these issues. The major obstacle to this experiment was balancing available resources and adequate replication. With limited aquaria in the lab and composite effluent provided by the WWTPs, we adjusted the number of replicate tanks, tank size, filters, and number of oysters per tank. We also had 
very limited funding to analyze effluent and tissues, resulting in compositing of samples at one time point, and only analyzing oysters exposed to one concentration (25\%). We suggest that future experiments utilize larger tanks w/proper filtration and mixing, increase replication of tanks and oysters, and analyze effluent and tissue samples at each sampling point and concentration, as funding allows. Our power analysis indicated that sample sizes of 6-10 tanks could be adequate for most response variables. To obtain enough effluent for more replication, combining effluent from multiple treatment plants or purchasing a composite sampling system that can collect more effluent per hour, are some potential options. These adjustments would require ample funding and resources and may help with designing future studies with a more ideal setup than ours.

\subsection{Conclusion}

In this study we evaluated effects and accumulation of PPCPs in Pacific oysters exposed to coastal WWTP effluent. Several PPCPs were identified in effluent from two small coastal WWTPs with low surrounding populations, providing occurrence data for populations that represent this region. Oysters exposed to $25 \%$ effluent from both treatment plants accumulated PPCPs in their tissues over the 12-week period; and effluent from the smaller WWTP at both concentrations (10\% and 25\%) suppressed oyster shell growth. Over time, all oysters experienced reduced mass and condition, indicating that stressful tank conditions may have overshadowed other potential effects from effluent exposure. This study provides important insights on uptake of PPCPs by marine bivalves and complexity in evaluating toxic effects of mixtures, which represent 
environmentally relevant conditions. We recommend that future studies increase replication, take more measures to decrease ambient stress in tank environments, and analyze for contaminants at multiple time points and concentrations.

\subsection{Acknowledgements}

We thank the three WWTP operators that collaborated on this study and provided weekly samples of effluent. We thank the oyster grower from Netarts Bay who donated oysters for the study. We acknowledge the many undergraduate and graduate students that assisted in the lab, particularly D. Horn, C. Heath, C. Homer, and K. Maloney. This work was funded by the Edward D. and Olive C. Bushby Scholarship from Portland State University and a Sigma Xi Grants in Aid of Research award granted to A. Ehrhart and a USGS-PSU Partnership Grant awarded to E. Granek.

\subsection{References}

Acir I-H, Guenther K. 2018. Endocrine-disrupting metabolites of alkylphenol ethoxylates - A critical review of analytical methods, environmental occurrences, toxicity, and regulation. Science of The Total Environment 635:1530-1546; doi:10.1016/j.scitotenv.2018.04.079.

Aerni H-R, Kobler B, Rutishauser BV, Wettstein FE, Fischer R, Giger W, et al. 2004. Combined biological and chemical assessment of estrogenic activities in 
wastewater treatment plant effluents. Anal Bioanal Chem 378:688-696; doi:10.1007/s00216-003-2276-4.

Akcha F, Barranger A, Bachère E, Berthelin CH, Piquemal D, Alonso P, et al. 2016. Effects of an environmentally relevant concentration of diuron on oyster genitors during gametogenesis: responses of early molecular and cellular markers and physiological impacts. Environ Sci Pollut Res 23:8008-8020; doi:10.1007/s11356-015-5969-2.

Almeida Â, Calisto V, Esteves VI, Schneider RJ, Soares AMVM, Figueira E, et al. 2018. Effects of single and combined exposure of pharmaceutical drugs (carbamazepine and cetirizine) and a metal (cadmium) on the biochemical responses of R. philippinarum. Aquatic Toxicology 198:10-19; doi:10.1016/j.aquatox.2018.02.011.

Arpin-Pont L, Bueno MJM, Gomez E, Fenet H. 2016. Occurrence of PPCPs in the marine environment: a review. Environ Sci Pollut Res 23:4978-4991; doi:10.1007/s11356-014-3617-x.

Bebianno MJ, Mello ACP, Serrano MAS, Flores-Nunes F, Mattos JJ, Zacchi FL, et al. 2017. Transcriptional and cellular effects of paracetamol in the oyster Crassostrea gigas. Ecotoxicology and Environmental Safety 144:258-267; doi:10.1016/j.ecoenv.2017.06.034.

Biel-Maeso M, Baena-Nogueras RM, Corada-Fernández C, Lara-Martín PA. 2018. Occurrence, distribution and environmental risk of pharmaceutically active 
compounds (PhACs) in coastal and ocean waters from the Gulf of Cadiz (SW Spain). Sci Total Environ 612:649-659; doi:10.1016/j.scitotenv.2017.08.279.

Brose DA, Kumar K, Liao A, Hundal LS, Tian G, Cox A, et al. 2019. A reduction in triclosan and triclocarban in water resource recovery facilities' influent, effluent, and biosolids following the U.S. Food and Drug Administration's 2013 proposed rulemaking on antibacterial products. Water Environment Research 91:715-721; doi:10.1002/wer.1101.

Bulayeva NN, Watson CS. 2004. Xenoestrogen-Induced ERK-1 and ERK-2 Activation via Multiple Membrane-Initiated Signaling Pathways. Environmental Health Perspectives 112:1481-1487; doi:10.1289/ehp.7175.

Canesi L, Ciacci C, Lorusso LC, Betti M, Gallo G, Pojana G, et al. 2007. Effects of Triclosan on Mytilus galloprovincialis hemocyte function and digestive gland enzyme activities: Possible modes of action on non target organisms. Comparative Biochemistry and Physiology Part C: Toxicology \& Pharmacology 145:464-472; doi:10.1016/j.cbpc.2007.02.002.

Castiglioni S, Bagnati R, Fanelli R, Pomati F, Calamari D, Zuccato E. 2006. Removal of Pharmaceuticals in Sewage Treatment Plants in Italy. Environmental Science \& Technology 40:357-363; doi:10.1021/es050991m.

Cavallin JE, Jensen KM, Kahl, Villeneuve Daniel L., Lee Kathy E., Schroeder Anthony L., et al. 2016. Pathway-based approaches for assessment of real-time exposure to an estrogenic wastewater treatment plant effluent on fathead minnow 
reproduction. Environmental Toxicology and Chemistry 35:702-716; doi:10.1002/etc.3228.

CDC NC for HS. 2020. Therapeutic Drug Use. Available: https://www.cdc.gov/nchs/fastats/drug-use-therapeutic.htm [accessed 7 October 2020].

Cortez FS, Seabra Pereira CD, Santos AR, Cesar A, Choueri RB, Martini G de A, et al. 2012. Biological effects of environmentally relevant concentrations of the pharmaceutical Triclosan in the marine mussel Perna perna (Linnaeus, 1758). Environmental Pollution 168:145-150; doi:10.1016/j.envpol.2012.04.024.

Coughlan J. 1969. The estimation of filtering rate from the clearance of suspensions. Marine Biology 2:356-358; doi:10.1007/BF00355716.

Daughton CG, Ternes TA. 1999. Pharmaceuticals and personal care products in the environment: agents of subtle change? Environ Health Perspect 107: 907-938.

Di Poi C, Evariste L, Séguin A, Mottier A, Pedelucq J, Lebel J, et al. 2016. Sub-chronic exposure to fluoxetine in juvenile oysters (Crassostrea gigas): uptake and biological effects. Environmental Science and Pollution Research International; Heidelberg 23:5002-5018; doi:http://dx.doi.org.proxy.lib.pdx.edu/10.1007/s11356-014-3702-1.

Díaz-Garduño B, Perales JA, Garrido-Pérez C, Martín-Díaz ML. 2018. Health status alterations in Ruditapes philippinarum after continuous secondary effluent exposure before and after additional tertiary treatment application. Environmental Pollution 235:720-729; doi:10.1016/j.envpol.2018.01.017. 
Dumas T, Bonnefille B, Gomez E, Boccard J, Castro NA, Fenet H, et al. 2020. Metabolomics approach reveals disruption of metabolic pathways in the marine bivalve Mytilus galloprovincialis exposed to a WWTP effluent extract. Science of The Total Environment 712:136551; doi:10.1016/j.scitotenv.2020.136551.

Dumbauld BR, Ruesink JL, Rumrill SS. 2009. The ecological role of bivalve shellfish aquaculture in the estuarine environment: A review with application to oyster and clam culture in West Coast (USA) estuaries. Aquaculture 290:196-223; doi:10.1016/j.aquaculture.2009.02.033.

Ehrhart AL, Granek EF, Nielsen-Pincus M, Horn DA. 2020. Leftover drug disposal: Customer behavior, pharmacist recommendations, and obstacles to drug take-back box implementation. Waste Management 118:416-425; doi:10.1016/j.wasman.2020.08.038.

Fabbri E, Franzellitti S. 2016. Human pharmaceuticals in the marine environment: Focus on exposure and biological effects in animal species. Environ Toxicol Chem 35:799-812; doi:10.1002/etc.3131.

Fabbri R, Montagna M, Balbi T, Raffo E, Palumbo F, Canesi L. 2014. Adaptation of the bivalve embryotoxicity assay for the high throughput screening of emerging contaminants in Mytilus galloprovincialis. Marine Environmental Research 99:18; doi:10.1016/j.marenvres.2014.05.007.

Fagin D. 2012. Toxicology: The learning curve. Nature News 490:462; doi: $10.1038 / 490462 \mathrm{a}$. 
FDA. 2019. Fact Sheet: FDA at a Glance. FDA. Available: https://www.fda.gov/aboutfda/fda-basics/fact-sheet-fda-glance [accessed 7 October 2020].

Fent K, Weston AA, Caminada D. 2006. Ecotoxicology of human pharmaceuticals. Aquatic Toxicology 76:122-159; doi:10.1016/j.aquatox.2005.09.009.

Flores-Nunes F, Gomes T, Company R, Moraes RRM, Sasaki ST, Taniguchi S, et al. 2015. Changes in protein expression of pacific oyster Crassostrea gigas exposed in situ to urban sewage. Environmental Science and Pollution Research 22:17267-17279; doi:10.1007/s11356-014-3821-8.

Fong PP, Molnar N. 2013. Antidepressants cause foot detachment from substrate in five species of marine snail. Marine Environmental Research 84:24-30; doi:10.1016/j.marenvres.2012.11.004.

Freitas AM, Rivas G, Campos-Mañas MC, López JLC, Agüera A, Pérez JAS. 2017. Ecotoxicity evaluation of a WWTP effluent treated by solar photo-Fenton at neutral pH in a raceway pond reactor. Environ Sci Pollut Res 24:1093-1104; doi:10.1007/s11356-016-7101-7.

Galtsoff PS. 1964. Morphology and structure of shell. Ch. 2. Fishery Bulletin of Fish and Wildlife Service 64: 16-47.

Gaw S, Thomas KV, Hutchinson TH. 2014. Sources, impacts and trends of pharmaceuticals in the marine and coastal environment. Philosophical Transactions of the Royal Society B: Biological Sciences 369:2013057220130572; doi:10.1098/rstb.2013.0572. 
Gray MW, Langdon CJ. 2018. Ecophysiology of the Olympia Oyster, Ostrea lurida, and Pacific Oyster, Crassostrea gigas. Estuaries and Coasts 41:521-535; doi:10.1007/s12237-017-0273-7.

Guruge KS, Goswami P, Tanoue R, Nomiyama K, Wijesekara RGS, Dharmaratne TS. 2019. First nationwide investigation and environmental risk assessment of 72 pharmaceuticals and personal care products from Sri Lankan surface waterways. Science of The Total Environment 690:683-695; doi:10.1016/j.scitotenv.2019.07.042.

Harding LB, Schultz IR, da Silva DAM, Ylitalo GM, Ragsdale D, Harris SI, et al. 2016. Wastewater treatment plant effluent alters pituitary gland gonadotropin mRNA levels in juvenile coho salmon (Oncorhynchus kisutch). Aquatic Toxicology 178:118-131; doi:10.1016/j.aquatox.2016.07.013.

Hedgespeth ML, Sapozhnikova Y, Pennington P, Clum A, Fairey A, Wirth E. 2012. Pharmaceuticals and personal care products (PPCPs) in treated wastewater discharges into Charleston Harbor, South Carolina. Science of The Total Environment 437:1-9; doi:10.1016/j.scitotenv.2012.07.076.

Honkoop PJC, Luttikhuizen PC, Piersma T. 1999. Experimentally extending the spawning season of a marine bivalve using temperature change and fluoxetine as synergistic triggers. Marine Ecology Progress Series 180:297-300; doi:10.3354/meps180297. 
Hope BK, Pillsbury L, Boling B. 2012. A state-wide survey in Oregon (USA) of trace metals and organic chemicals in municipal effluent. Science of The Total Environment 417-418:263-272; doi:10.1016/j.scitotenv.2011.12.028.

Ialongo C. 2016. Understanding the effect size and its measures. Biochem Med (Zagreb) 26:150-163; doi:10.11613/BM.2016.015.

Jenkins S, Wang J, Eltoum I, Desmond R, Lamartiniere C. 2011. Chronic Oral Exposure to Bisphenol A Results in a Nonmonotonic Dose Response in Mammary Carcinogenesis and Metastasis in MMTV-erbB2 Mice. Environmental Health Perspectives 119:1604-1609; doi:10.1289/ehp.1103850.

Khan B, Burgess RM, Fogg SA, Cantwell MG, Katz DR, Ho KT. 2018. Cellular responses to in vitro exposures to $\beta$-blocking pharmaceuticals in hard clams and Eastern oysters. Chemosphere 211:360-370;

doi:10.1016/j.chemosphere.2018.07.156.

Kostich MS, Batt AL, Lazorchak JM. 2014. Concentrations of prioritized pharmaceuticals in effluents from 50 large wastewater treatment plants in the US and implications for risk estimation. Environmental Pollution 184:354-359; doi:10.1016/j.envpol.2013.09.013.

Lara-Martín PA, González-Mazo E, Petrovic M, Barceló D, Brownawell BJ. 2014. Occurrence, distribution and partitioning of nonionic surfactants and pharmaceuticals in the urbanized Long Island Sound Estuary (NY). Marine Pollution Bulletin 85:710-719; doi:10.1016/j.marpolbul.2014.01.022. 
Loraine GA, Pettigrove ME. 2006. Seasonal variations in concentrations of pharmaceuticals and personal care products in drinking water and reclaimed wastewater in southern California. Environ Sci Technol 40:687-695; doi:10.1021/es051380x.

Lucas A, Beninger PG. 1985. The use of physiological condition indices in marine bivalve aquaculture. Aquaculture 44:187-200; doi:10.1016/0044-8486(85)902431.

Mair P, Wilcox R. 2020. Robust statistical methods in R using the WRS2 package. Behav Res 52:464-488; doi:10.3758/s13428-019-01246-w.

Meador JP, Yeh A, Young G, Gallagher EP. 2016. Contaminants of emerging concern in a large temperate estuary. Environmental Pollution 213:254-267; doi:10.1016/j.envpol.2016.01.088.

Medeiros ID, Siebert MN, Toledo-Silva G, Rodrigues TB, Marques MRF, Bainy ACD. 2008. Induced gene expression in oyster Crassostrea gigas exposed to sewage. Environmental Toxicology and Pharmacology 26:362-365; doi:10.1016/j.etap.2008.05.004.

Mezzelani M, Gorbi S, Regoli F. 2018. Pharmaceuticals in the aquatic environments: Evidence of emerged threat and future challenges for marine organisms. Marine Environmental Research 140:41-60; doi:10.1016/j.marenvres.2018.05.001.

Minarik TA, Vick JA, Schultz MM, Bartell SE, Martinovic-Weigelt D, Rearick DC, et al. 2014. On-Site Exposure to Treated Wastewater Effluent Has Subtle Effects on 
Male Fathead Minnows and Pronounced Effects on Carp. JAWRA Journal of the American Water Resources Association 50:358-375; doi:10.1111/jawr.12167.

Mo C, Neilson B. 1994. Standardization of oyster soft tissue dry weight measurements. Water Research 28:243-246; doi:10.1016/0043-1354(94)90140-6.

Mottier A, Séguin A, Devos A, Pabic CL, Voiseux C, Lebel JM, et al. 2015. Effects of subchronic exposure to glyphosate in juvenile oysters (Crassostrea gigas): From molecular to individual levels. Marine Pollution Bulletin 95:665-677; doi:10.1016/j.marpolbul.2014.10.026.

Olaniyan LWB, Mkwetshana N, Okoh AI. 2016. Triclosan in water, implications for human and environmental health. SpringerPlus 5:1639; doi:10.1186/s40064-0163287-x.

Oliveira P, Almeida Â, Calisto V, Esteves VI, Schneider RJ, Wrona FJ, et al. 2017. Physiological and biochemical alterations induced in the mussel Mytilus galloprovincialis after short and long-term exposure to carbamazepine. Water Research 117:102-114; doi:10.1016/j.watres.2017.03.052.

Palmer TA, Uehling P, Pollack JB. 2015. Using oyster tissue toxicity as an indicator of disturbed environments. Int J Environ Sci Technol 12:2111-2116; doi:10.1007/s13762-014-0745-2.

Papageorgiou M, Kosma C, Lambropoulou D. 2016. Seasonal occurrence, removal, mass loading and environmental risk assessment of 55 pharmaceuticals and personal care products in a municipal wastewater treatment plant in Central Greece. 
Science of The Total Environment 543:547-569;

doi:10.1016/j.scitotenv.2015.11.047.

Park MS, Kim YD, Kim B-M, Kim Y-J, Kim JK, Rhee J-S. 2016. Effects of Antifouling Biocides on Molecular and Biochemical Defense System in the Gill of the Pacific Oyster Crassostrea gigas. PLOS ONE 11:e0168978;

doi:10.1371/journal.pone.0168978.

Pauley GB, Van Der Raay B, Troutt D. 1988. Species Profiles: Life Histories and Environmental Requirements of Coastal Fishes and Invertebrates (Pacific Northwest), Pacific Oyster.

Peters JR, Granek EF. 2016. Long-term exposure to fluoxetine reduces growth and reproductive potential in the dominant rocky intertidal mussel, Mytilus californianus. Science of The Total Environment 545-546:621-628; doi:10.1016/j.scitotenv.2015.12.118.

Priac A, Morin-Crini N, Druart C, Gavoille S, Bradu C, Lagarrigue C, et al. 2017. Alkylphenol and alkylphenol polyethoxylates in water and wastewater: A review of options for their elimination. Arabian Journal of Chemistry 10:S3749-S3773; doi:10.1016/j.arabjc.2014.05.011.

Prichard E, Granek EF. 2016. Effects of pharmaceuticals and personal care products on marine organisms: from single-species studies to an ecosystem-based approach. Environmental Science and Pollution Research 23:22365-22384; doi:10.1007/s11356-016-7282-0. 
Revel M, Châtel A, Perrein-Ettajani H, Bruneau M, Akcha F, Sussarellu R, et al. 2020. Realistic environmental exposure to microplastics does not induce biological effects in the Pacific oyster Crassostrea gigas. Marine Pollution Bulletin 150:110627; doi:10.1016/j.marpolbul.2019.110627.

Rivera-Jaimes JA, Postigo C, Melgoza-Alemán RM, Aceña J, Barceló D, López de Alda M. 2018. Study of pharmaceuticals in surface and wastewater from Cuernavaca, Morelos, Mexico: Occurrence and environmental risk assessment. Science of The Total Environment 613-614:1263-1274; doi:10.1016/j.scitotenv.2017.09.134.

Rout PR, Zhang TC, Bhunia P, Surampalli RY. 2021. Treatment technologies for emerging contaminants in wastewater treatment plants: A review. Science of The Total Environment 753:141990; doi:10.1016/j.scitotenv.2020.141990.

Salgueiro-González N, Muniategui-Lorenzo S, López-Mahía P, Prada-Rodríguez D. 2017. Trends in analytical methodologies for the determination of alkylphenols and bisphenol A in water samples. Analytica Chimica Acta 962:1-14; doi:10.1016/j.aca.2017.01.035.

Schlüter-Vorberg L, Knopp G, Cornel P, Ternes T, Coors A. 2017. Survival, reproduction, growth, and parasite resistance of aquatic organisms exposed onsite to wastewater treated by advanced treatment processes. Aquatic Toxicology 186:171-179; doi:10.1016/j.aquatox.2017.03.001.

Serrano MA, S, Gonzalez-rey M, Mattos JJ, Flores-nunes F, Mello ÁC, et al. 2015. Differential gene transcription, biochemical responses, and cytotoxicity assessment in Pacific oyster Crassostrea gigas exposed to ibuprofen. 
Environmental Science and Pollution Research International; Heidelberg 22:17375-17385; doi:http://dx.doi.org.proxy.lib.pdx.edu/10.1007/s11356-0144023-0.

Teixeira J. 2016. Effects of Antibiotic Mixtures across Marine Intertidal Trophic Levels: Examining Environmentally-Relevant Contaminant Concentrations. Dissertations and Theses; doi:10.15760/etd.5263.

Teixeira JR, Granek EF. 2017. Effects of environmentally-relevant antibiotic mixtures on marine microalgal growth. Science of The Total Environment 580:43-49; doi:10.1016/j.scitotenv.2016.11.207.

Ternes TA. 1998. Occurrence of drugs in German sewage treatment plants and. Water Research 32:3245-3260; doi:10.1016/S0043-1354(98)00099-2.

Ternes TA, Stüber J, Herrmann N, McDowell D, Ried A, Kampmann M, et al. 2003. Ozonation: a tool for removal of pharmaceuticals, contrast media and musk fragrances from wastewater? Water Research 37:1976-1982; doi:10.1016/S00431354(02)00570-5.

US EPA. 2015. National Recommended Water Quality Criteria - Aquatic Life Criteria Table. US EPA. Available: https://www.epa.gov/wqc/national-recommendedwater-quality-criteria-aquatic-life-criteria-table [accessed 9 November 2020].

US EPA. 2010. Nonylphenol (NP) and Nonylphenol Ethoxylates (NPEs) Action Plan. Assessing and Managing Chemicals under TSCA. Available: https://www.epa.gov/assessing-and-managing-chemicals-under-tsca/nonylphenolnp-and-nonylphenol-ethoxylates-npes [accessed 22 April 2019]. 
US EPA. 2008. White Paper: Aquatic Life Criteria for Contaminants of Emerging Concern Part 1: General Challenges and Recommendations. Available: https://www.epa.gov/sites/production/files/201508/documents/white_paper_aquatic_life_criteria_for_contaminants_of_emerging_ concern_part_i_general_challenges_and_recommendations_1.pdf [accessed 29 October 2020].

Vajda AM, Kumar A, Woods M, Williams M, Doan H, Tolsher P, et al. 2015. Integrated assessment of wastewater treatment plant effluent estrogenicity in the Upper Murray River, Australia, using the native Murray rainbowfish (Melanotaenia fluviatilis). Environ Toxicol Chem 34:1078-1087; doi:10.1002/etc.2895.

Vidal-Dorsch DE, Bay SM, Maruya K, Snyder SA, Trenholm RA, Vanderford BJ. 2012. Contaminants of emerging concern in municipal wastewater effluents and marine receiving water. Environmental Toxicology \& Chemistry 31:2674-2682; doi:10.1002/etc.2004.

Vieno N, Tuhkanen T, Kronberg L. 2007. Elimination of pharmaceuticals in sewage treatment plants in Finland. Water Research 41:1001-1012; doi:10.1016/j.watres.2006.12.017.

Vimalkumar K, Seethappan S, Pugazhendhi A. 2019. Fate of Triclocarban (TCC) in aquatic and terrestrial systems and human exposure. Chemosphere 230:201-209; doi:10.1016/j.chemosphere.2019.04.145.

Wehmas LC, Cavallin JE, Durhan EJ, Kahl MD, Martinovic D, Mayasich J, et al. 2011. Screening complex effluents for estrogenic activity with the T47D-KBluc cell 
bioassay: Assay optimization and comparison with in vivo responses in fish.

Environmental Toxicology and Chemistry 30:439-445; doi:10.1002/etc.388. 


\title{
Chapter 4: Leftover drug disposal: customer behavior, pharmacist recommendations, and obstacles to drug take-back box implementation
}

Published in the peer-reviewed journal, Waste Management, with the following citation:

Ehrhart AL, Granek EF, Nielsen-Pincus M, Horn DA. 2020. Leftover drug disposal:

Customer behavior, pharmacist recommendations, and obstacles to drug take-back box

implementation. Waste Management 118:416-425; doi:10.1016/j.wasman.2020.08.038.

\begin{abstract}
Production and use of pharmaceuticals in the United States is high and continues to grow. This combined with poor wastewater removal rates for drugs in excreted waste, and improper pharmaceutical disposal leads to the presence of pharmaceuticals in freshand marine waters and wildlife. In the United States, safe drug take-back boxes, or dropboxes, were established in pharmacies after federal legislation passed in 2014, allowing for year-round safe collection of leftover pharmaceuticals. The overarching objective of this work was to identify opportunities for improving access to proper pharmaceutical disposal. We assessed consumer behavior regarding drug disposal choices and knowledge of dropboxes at pharmacies, investigated pharmacist recommendations and attitudes towards leftover drug disposal, and compared responses at locations with and without dropboxes. We also explored obstacles to dropbox adoption and usage. We found that customer awareness of dropboxes as well as knowledge about risks of improper disposal are low, however awareness was greater at pharmacies with dropboxes. Additionally, pharmacists at dropbox locations were more consistent in their
\end{abstract}


messaging to customers, more likely to recommend proper disposal methods, and more supportive of drug take-back programs. Through the focus group, we learned that further consumer education would overwhelm the capacity of the existing dropboxes. Based on our findings, we recommend solutions to improper disposal focus on legislation mandating dropboxes at pharmacies and pressure on the pharmaceutical industry to fund proper disposal of unused pharmaceuticals.

\subsection{Introduction}

\subsubsection{Leftover Drug Disposal Estimates}

Pharmaceutical production constitutes a multi-billion-dollar industry in the United States (US), with total spending of $\$ 424.8$ billion in 2015 (Aitken 2016). The number of dispensed prescription drugs has increased by about one to two percent each year and reached 4.37 billion in 2015 (Aitken 2016). From 2008-2016, the US Food and Drug Administration approved an average of 31 new drugs per year (U.S. FDA CDER 2017). According to a study that estimated annual wastage costs from unused medication in consumer homes, approximately 1.6 billion prescription medications and $\$ 117.4$ billion worth of drugs are disposed of annually in the US (Law et al. 2015). However, the actual number and economic value of unused medicines in the US is unknown. Consumed and wasted drugs enter the aquatic environment through two major pathways: excretion from the body of unmetabolized compounds and disposal of unused medications via sewage and landfills (Gaw et al. 2014). Pharmaceuticals and their metabolites are not completely removed by wastewater treatment plants before effluent is released to rivers, estuaries, 
and coastal waters (Vidal-Dorsch et al. 2012) and can leach into groundwater from landfill sites (Slack et al. 2005). Limited data on disposed quantities has led to skepticism about disposal being a significant source of pollution in comparison to excretion (Ruhoy and Daughton 2007). However, modeling, consumer drug disposal estimates, and wastewater concentration tracking research continue to suggest and highlight that disposal contributes to environmental presence (e.g., Stoddard and Huggett 2015, Kümmerer 2010, Daughton and Ruhoy 2009, Bound and Voulvoulis 2005). For example, estimates from 2005 coroner reports in Clark County, Nevada, indicate that 17.9 metric tons of drugs are likely disposed of annually in the US from homes of deceased individuals alone (Ruhoy and Daughton 2007). In 2005 there were approximately 267,500 deaths in the US that would require a coroner report (Ruhoy and Daughton 2007). Most of these drugs (92\% in Clark County) are flushed down the toilet at the residence (Ruhoy and Daughton 2007). Additionally, the volume of drugs collected at drug take-back events demonstrates that large quantities are being stored and disposed of by consumers, constituting a likely source of pollution. Since the fall of 2010, the US Drug Enforcement Administration has collected a total of 5,908 tons of unwanted drugs at bi-annual take-back events across the US (Martin 2019), which has a population of 329.1 million people. In September 2015, alone, the most recent event for which data are available, 4.5 tons of leftover medications were collected in Oregon (population of 4.02 million) through the annual drug take-back event (Oregon Health Authority n.d.). Studies on consumer disposal have reported that up to $94-97 \%$ of consumers have leftover drugs in their home (Abahussain et al. 2006, Kusturica et al. 2012). 


\subsubsection{Drugs in the Environment}

Pharmaceuticals and their metabolites are consistently detected in marine and aquatic environments and species worldwide (Arpin-Pont et al. 2016, Hughes et al. 2013). Since medications are consumed regularly and therefore continually discharged from municipal wastewater year-round, they have been deemed "pseudo-persistent" in the environment (Daughton and Ternes 1999). Exposure to environmentally relevant concentrations of some pharmaceuticals has demonstrated negative effects on biota. For example, the antidepressant, fluoxetine (Prozac), represses growth, feeding rate, and reproductive output in marine mussels (Peters and Granek 2016) and antibiotics such as trimethoprim and sulfamethoxazole affect growth of algal species consumed by bivalves (Teixeira and Granek 2017). Reducing pharmaceutical pollution into aquatic and marine systems will require multiple interventions, including wastewater treatment improvements, increased proper disposal, and changes to drug prescription practices and drug formulation (Kümmerer 2010, Daughton and Ternes 1999). While prioritizing upgrading of wastewater treatment plant technology would likely lead to the highest reduction in pharmaceutical pollution, this is costly and infeasible for most areas in the US to implement in the short-term. Proper disposal is a feasible option to reduce partial loadings to the environment and provides public health benefits (Kümmerer 2010). Understanding pharmaceutical disposal guidelines and resultant practices can shed light on the needs and potential effectiveness of this intervention. 


\subsubsection{Drug Disposal Recommendations}

In the US, recommendations for disposal of leftover medications are provided by the following federal agencies: Food and Drug Administration (FDA), Drug Enforcement Administration (DEA), and Environmental Protection Agency (EPA). Recommendations vary among agencies and include methods that pose threats to the environment (Table 4.1) such as putting in the trash and flushing down the toilet/sink (for harmful substances; US FDA), as well as environmentally safer methods including taking to a semi-annual take-back event organized by the US DEA (U.S. FDA 2019). While the US FDA recommends flushing, the US EPA discourages flushing (US EPA 2015) and the US DEA directs customers to the FDA and EPA websites for household disposal (US DEA n.d.a).

Table 4.1 Pharmaceutical disposal recommendations from federal agencies in the United States.

\begin{tabular}{lccc}
\hline & $\begin{array}{c}\text { Food and Drug } \\
\text { Administration }\end{array}$ & $\begin{array}{c}\text { Drug Enforcement } \\
\text { Agency }\end{array}$ & $\begin{array}{l}\text { Environmental } \\
\text { Protection Agency }\end{array}$ \\
\hline Place in trash & $\checkmark$ & & \\
Flush down sink/toilet & $\checkmark$ & $\checkmark$ & $\checkmark$ \\
Take to semi-annual drug take-back event & $\checkmark$ & $\checkmark$ & $\checkmark$ \\
$\begin{array}{l}\text { Place in trash with undesirable substance } \\
\begin{array}{l}\text { Direct to other federal websites for } \\
\text { instructions }\end{array}\end{array}$ & & & \\
\hline
\end{tabular}

Many of the federally recommended disposal options pose environmental and public health risks. Flushing of drugs contributes directly to contamination of waterways as many pharmaceuticals have low removal rates in wastewater treatment plants (Vieno et al. 2007). Drugs in landfills can leach into groundwater, causing contamination over longer periods of time (Gaw et al. 2014). Storing medications at home for a drug takeback event increases risk of illegal or accidental ingestion (Stewart et al 2015). 


\subsubsection{Drug Take-Back Boxes}

Drug take-back boxes, or dropboxes, located within pharmacies are one option for increasing safe disposal rates. Until recently, pharmacies in the United States were not permitted to collect unused medication from customers. The only safe disposal method was to take drugs to a law enforcement agency (e.g., police station) or a bi-annual drug collection event (US DEA 2014). Federal legislation in 2014 allowed retail pharmacies to become authorized collectors of unused pharmaceuticals and establish dropboxes within the store to collect leftover medications year-round (US DEA 2014). Pharmacies throughout the US have taken advantage of this opportunity. For example, Walgreens currently has dropboxes in 1,500 locations throughout 46 states (Walgreens 2019). Dropbox contents are collected by a DEA-authorized vendor and are typically incinerated or disposed of as hazardous waste, considered the most environmentally sound disposal methods available (US DEA 2014). Improving proper disposal of pharmaceuticals with dropbox usage could provide a convenient, year-round system to alleviate public health concerns and address environmental contamination. Such contamination is evident by occurrence of drugs in landfill leachate, where the known source is landfill disposal. In 2010, leachate from three landfills in Maine that only receive household waste contained pharmaceutical concentrations of $117,000 \mathrm{ng} / \mathrm{L}$ for acetaminophen (pain reliever), 169 ng/L for ciprofloxacin (antibiotic), and $57 \mathrm{ng} / \mathrm{L}$ for cocaine (Lubick 2010). These concentrations are comparable to those found in treated municipal wastewater effluent (Meador et al. 2016, Fent et al. 2006), which is a demonstrated major source of 
pharmaceuticals to the environment due to low removal rates of many drugs during treatment (Jones et al. 2005). Similar concentrations in leachate indicate that disposed drugs may have an impact on aquatic pollution, and proper disposal could be effective in reducing environmental contamination.

\subsubsection{Pharmacist Communication: Drug Use and Disposal}

Pharmacists in retail pharmacies play an important role in the dissemination of customer medication use and disposal information. Research demonstrates that pharmacists can increase efficient use of drugs through patient education and reduction of over-prescription (Singleton et al. 2014), indicating their potential to increase safe drug disposal through communication with their customers. Current research shows that communication about drug disposal between pharmacists and customers occurs variably. In a study in which 142 California pharmacists reported frequency of giving medication disposal information to patients, $13.6 \%$ said they gave instructions once a year, $50.7 \%$ said once a month, and $23.6 \%$ said every week (Tai et al. 2016). Yet only $15.9 \%$ of pharmacists in the same study had knowledge of all appropriate disposal methods (Tai et al. 2016). Interventions to improve frequency and accuracy of pharmacist communication with customers require improved overall knowledge by pharmacists regarding drug disposal to inform recommendations (Singleton et al. 2014).

\subsubsection{Study Objectives}


Given the recent changes in authority to allow dropboxes in retail pharmacies, we examined customer disposal behavior, pharmacist recommendations and attitudes regarding disposal of leftover drugs in the context of dropbox presence, and proper drug disposal implementation challenges. We addressed the following objectives:

1) Assess customer disposal practices for leftover drugs and awareness of dropboxes in retail pharmacies.

2) Investigate pharmacist recommendations and attitudes regarding leftover drug disposal.

3) Compare customer and pharmacist responses at pharmacies with and without dropboxes.

4) Explore obstacles to dropbox adoption and usage and identify information to provide to legislators, pharmacies, and/or the public to increase availability, awareness, and use of dropboxes.

This research was undertaken to identify potential outreach and/or policy decisions to improve proper drug disposal and reduce environmental and human impacts from current disposal methods.. Knowledge of disposal patterns when dropboxes are available can identify their effectiveness in improving proper drug disposal, which in turn, may improve public health outcomes (e.g., reduction in accidental or intentional ingestion of unprescribed pharmaceuticals) and reduce pollution.

\subsection{Methods}

\subsubsection{Study Area}


Research was conducted in the Portland metropolitan area, which includes the major cities of Portland, Beaverton, and Hillsboro, OR and Vancouver, WA, and the surrounding suburbs in seven counties (Clackamas, Columbia, Multnomah, Washington, Yamhill, Clark, and Skamania) (OMB 2006). The most recent census data show a population size of 2,478,996 for this area (US Census Bureau 2018). Our study took place within the four quadrants of the city of Portland (Southwest, Southeast, Northwest, Northeast) and the following surrounding suburbs in Oregon: Tigard, Beaverton, Gresham, Hillsboro. Of the roughly 500 pharmacies in this area, approximately $30(\sim 6 \%)$ are registered as authorized collectors with dropboxes (US DEA n.d.b).

\subsubsection{Surveys and Interviews}

This research was approved by the Institutional Review Board (IRB) at Portland State University and consent was obtained from all participants prior to conducting surveys and interviews. From October 2017 to February 2018, we conducted interviews with pharmacists and surveys with customers at retail pharmacies. We identified pharmacies with and without onsite dropboxes in each quadrant of the city and four surrounding suburbs using Google maps and the DEA registry of authorized drug collectors. Pharmacies were randomly chosen with 1-5 pharmacies in each quadrant and suburb. This resulted in a list of 40 pharmacies, 14 with dropboxes and 26 without dropboxes. At each pharmacy, we contacted the pharmacist or pharmacy technician over the phone and requested a five-minute interview. If the pharmacist agreed to an interview, we asked the following five questions about their recommendations for leftover drug disposal and their attitudes about drug take-back programs: 
1. What is your role in the distribution of pharmaceuticals to patients?

2. What do you typically tell your patients to do with their leftover pharmaceuticals?

3. What do you know about your employer's policies regarding drug take back programs?

4. What are your attitudes regarding drug take-back programs? What do you see as the pros and cons?

5. From your perspective, what are the general attitudes of your co-workers regarding drug take-back programs?

During each interview, we took detailed notes while the pharmacists were speaking that were later entered into a spreadsheet. Responses to each question were reviewed and thematically coded.

At the end of the interview, we asked permission to visit the pharmacy and conduct surveys with customers. Some pharmacists granted permission, some refused, and others directed us to the store or pharmacy manager to obtain permission. At pharmacies where we were permitted to distribute onsite surveys, we identified our sample by standing outside of the store with the pharmacy (e.g., Walgreens) and asking entering and exiting customers to fill out anonymous paper surveys about leftover drug disposal practices. Only participants that were 18 years or older were given the survey. The survey consisted of 19 multiple choice questions organized into the following topics (Figure C2): customer leftover drug disposal practices, recommendations received from pharmacists/doctors/nurses for medication disposal, obstacles to using a drug take-back box, knowledge of the nearest drug take-back box, importance of disposing of drugs 
properly, and demographic information. Questions generally instructed participants to choose one answer. Two questions requested a follow up open-ended response if the participant answered yes: 1) what is the location of the drug take-back box nearest to you? and 2) why is it important to dispose of drugs properly? When appropriate, multiple choice questions included an "other" option with a blank space for a written response. We entered all answers from customer surveys into an electronic Google form, which compiled responses into a spreadsheet that was reviewed for consistency and accuracy before analysis. R Studio version 3.4.1 and Microsoft Excel were used to calculate summary counts and percentages for each question following the methods of similar studies that reported disposal rates (Law et al. 2015, Wieczorkiewicz et al. 2013, Kusturica et al. 2012, Seehusen and Edwards 2006, Abahussain et al. 2005). We compared responses of customers that took the survey at locations with and without dropboxes, though customers may have encountered dropoxes at other locations previously. Due to the small sample size $(n=129)$, data analysis beyond summary statistics was not employed.

\subsubsection{Focus Group}

On February 21, 2018, we facilitated a focus group consisting of individuals with expert knowledge on pharmaceutical disposal practices, dropbox implementation at pharmacies, and current legislation efforts. The overarching goal of the focus group was to explore obstacles for pharmacies to establish drug take-back boxes and obtain input on what type of information would be helpful to provide to pharmacies and/or the public to 
increase the presence, awareness, and use of dropboxes. We identified potential participants by contacting pharmacy managers who had given permission for a site visit and through discussion with medical professionals involved in project development. Some invitees put us in touch with other organizations that would be interested and able to provide relevant information in the focus group. We contacted a total of ten individuals via email to assess their interest in participating, and sent an official invitation to seven people. The two-hour evening focus group occurred at Portland State University and included an overview presentation of the research context and preliminary interview and survey results, and a facilitated discussion of the following questions:

1. What are the challenges to improving proper disposal of leftover drugs?

2. What did you/do student pharmacists learn in your/their training about leftover drug disposal?

3. In your experience, what have you seen that works to improve public use and awareness of dropboxes and proper leftover drug disposal?

4. How could information about dropboxes best be delivered to customers and pharmacists (e.g., pamphlet, stickers for bags/pill bottles)?

The focus group discussion was recorded and detailed notes, including quotes and major themes discussed, were taken during the focus group. Notes were summarized into a narrative following the focus group and from this summary, we identified major themes relevant to our goals and the body of literature regarding leftover drug disposal. The summary and themes were reviewed by the three facilitators for accuracy. 


\subsection{Results}

\subsubsection{Customer Surveys}

We collected a total of 129 customer surveys from 14 pharmacies, five with a dropbox, and nine without a dropbox. A roughly equal number of participants were male and female $(48.1 \%, \mathrm{n}=62)$ with $3.9 \%(\mathrm{n}=5)$ identifying as other genders. The majority of respondents were white $(76.7 \%, \mathrm{n}=99)$ and from the age ranges of $45-54(32.6 \%, \mathrm{n}=42)$ and 55-64 (20.9\%, $\mathrm{n}=27)$ years old. Annual household income mode was $\$ 75,000$ $\$ 95,000$ at $26.8 \%(n=34)$. Detailed demographic characteristics are presented in Table

\section{2 .}

Table 4.2 Demographic information of survey respondents. Difference in sample size by question is due to exclusion of unanswered questions.

\begin{tabular}{|c|c|}
\hline Variable & Frequency \\
\hline \multicolumn{2}{|l|}{ Gender } \\
\hline Female & $48.1 \%(62)$ \\
\hline Male & $48.1 \%(62)$ \\
\hline Other & $3.9 \%(5)$ \\
\hline \multicolumn{2}{|l|}{ Age } \\
\hline 18-24 years & $8.5 \%(11)$ \\
\hline $25-34$ years & $13.2 \%(17)$ \\
\hline $35-44$ years & $10.9 \%(14)$ \\
\hline $45-54$ years & $32.6 \%(42)$ \\
\hline 55-64 years & $20.9 \%(27)$ \\
\hline $65-75$ years & $9.3 \%(12)$ \\
\hline Over 75 years & $4.7 \%(6)$ \\
\hline \multicolumn{2}{|l|}{ Race } \\
\hline White & $76.6 \%(99)$ \\
\hline Hispanic/Latino & $11.6 \%(15)$ \\
\hline Black or African American & $8.5 \%(11)$ \\
\hline American Indian/Alaska Native & $0.8 \%(1)$ \\
\hline Japanese & $0.8 \%(1)$ \\
\hline Korean & $0.8 \%(1)$ \\
\hline Other Asian & $0.8 \%(1)$ \\
\hline \multicolumn{2}{|l|}{ Education } \\
\hline Graduate School & $11.7 \%(15)$ \\
\hline 4-year College & $36.7 \%(47)$ \\
\hline Associates Degree & $10.2 \%(13)$ \\
\hline Some College & $14.8 \%(19)$ \\
\hline
\end{tabular}




$\begin{array}{ll}\text { Vocational School } & 8.6 \%(11) \\ \text { High School or Diploma } & 17.2 \%(22) \\ \text { Elementary/Junior High } & 0.8 \%(1) \\ & \\ \text { Household Annual Income } & \\ \$ 10,000-\$ 14,000 & 3.9 \%(5) \\ \$ 15,000-\$ 24,000 & 3.1 \%(4) \\ \$ 25,000-\$ 34,000 & 12.6 \%(16) \\ \$ 35,000-\$ 49,000 & 19.7 \%(25) \\ \$ 50,000-\$ 74,000 & 19.7 \%(25) \\ \$ 75,000-\$ 95,000 & 26.8 \%(34) \\ \$ 100,000-\$ 149,000 & 12.6 \%(16) \\ \$ 150,000 \text { and above } & 1.6 \%(2) \\ & \\ \text { Household Size }(\mathrm{n}=129) & \\ 1 & 10.9 \%(14) \\ 2 & 34.9 \%(45) \\ 3 & 30.2 \%(39) \\ 4 & 14.7 \%(19) \\ 6 & 7.0 \%(9) \\ 8 \text { to } 7 & 0.8 \%(1) \\ 10 \text { or more } & 0.8 \%(1) \\ \end{array}$

When asked about leftover drug disposal, $41.7 \%$ of customers reported storing drugs at home $(n=50)$, with a negligible difference at locations with $(40.4 \%, n=19)$ and without dropboxes $(42.5 \%, \mathrm{n}=31)$. For the remaining disposal methods, $27.5 \%$ put them in the trash $(n=33), 15.8 \%$ flushed down the toilet $(n=19), 8.3 \%$ used a dropbox $(n=10)$, and $4.2 \%$ took to a police station $(n=5)$ (Table 4.3). Differences were apparent based on dropbox presence in all categories; notable among customers surveyed at dropbox locations, $6.7 \%$ fewer respondents reported throwing away leftover pharmaceuticals and $3.8 \%$ more respondents reported using dropboxes than respondents at locations without a dropbox (Table 4.3). To further explore customer disposal, we grouped responses by behaviors that were safe (taking to a dropbox, police station, or pharmacy) and unsafe (storing at home, flushing, throwing away). Overall, most customers used unsafe options 
, but a higher percentage of safe disposal behaviors were reported at dropbox sites than at locations lacking a dropbox (Table 4.3).

With respect to obtaining information about disposal, 60\% ( $\mathrm{n}=75$ ) of customers said they received instructions from pharmacists, doctors, or nurses, with the majority reporting that these individuals recommended throwing in the trash $(25.6 \%, \mathrm{n}=32)$, followed by flushing $(20 \%, \mathrm{n}=25)$ and using a dropbox $(8.8 \%, \mathrm{n}=11)$. At locations with dropboxes, $11.8 \%(\mathrm{n}=6)$ of customers reported being told to flush, compared to $25.7 \%$ $(n=19)$ at locations without dropboxes (Table 4.3). Additionally, a higher percentage of customers reported being told to use a dropbox at locations with dropboxes $(15.7 \%, \mathrm{n}=8)$ compared to those without dropboxes $(4.1 \%, \mathrm{n}=3)$ (Table 4.3). When grouped into safe and unsafe recommendations, a similar pattern emerges with four times as many customers at dropbox sites reportedly receiving instructions for safe disposal (Table 4.3). Customers stated that they would seek varied sources of information for disposal instructions, including online sources $(51.6 \%, \mathrm{n}=63)$, asking a pharmacist $(30.3 \%, \mathrm{n}=37)$, and checking the medicine label $(18.0 \%, \mathrm{n}=22)$ (Table 4.3). Online sources were the preferred method at both location types, but at locations with dropboxes more customers preferred checking the medicine label (dropbox: $24.5 \%$, $\mathrm{n}=12$; no dropbox: $13.5 \%$, $\mathrm{n}=10$ ), and fewer preferred asking a pharmacist (dropbox: $22.4 \%, \mathrm{n}=11$; no dropbox: $35.1 \%, \mathrm{n}=26)$ (Table 4.3).

In general, customers had low awareness of dropboxes and drug disposal implications; this was marginally improved by dropbox presence. When asked about knowledge of the nearest drug take-back box, only $14.0 \%(\mathrm{n}=18)$ of customers said they 
knew the nearest location. A higher percentage reported knowledge of a dropbox at dropbox locations $(23.5 \%, \mathrm{n}=12)$ compared to non-dropbox locations $(7.7 \%, \mathrm{n}=6)$, indicating that presence of a dropbox may increase awareness (Table 4.3). However, awareness was surprisingly low considering the proximity of the dropbox at these locations during survey administration. Just over a third of customers $(35 \%, \mathrm{n}=46)$ said they knew why it was important to dispose of drugs properly (Table 4.3). This percentage was higher at locations with dropboxes $(42.1 \%, \mathrm{n}=21)$ compared to locations without dropboxes $(32.5 \%, \mathrm{n}=25)$ (Table 4.3). Thirty customers listed a reason to dispose of drugs properly and five individuals listed two reasons $(n=35)$. The highest percentage mentioned environmental concerns or pollution $(51.4 \%, \mathrm{n}=18)$, and others listed safety $(45.7 \%, \mathrm{n}=16)$ and drug expiration $(2.9 \%, \mathrm{n}=1)$. When asked about obstacles to using dropboxes, $56 \%(n=70)$ of customers said they did not know dropboxes existed until taking the survey, again showing low awareness. However, this percentage was lower at locations with dropboxes (dropbox: 50\%, $n=25$; no dropbox: $60.0 \%, n=45$ ). When examining relationships between awareness and behavior, we find that there is a disconnect between these factors. Many more customers reported awareness of importance of proper disposal (dropbox: $41.2 \%, \mathrm{n}=21$; no dropbox: $32.5 \%, \mathrm{n}=25$ ) and knowledge of dropbox locations (dropbox: $23.5 \%, \mathrm{n}=12$; no dropbox: $7.7 \%, \mathrm{n}=6$ ), than actually said they used a dropbox (dropbox: 10.6\%, n=5; no dropbox: 6.8\%, n=5 ) (Table 4.3), indicating that other factors may inhibit consumer use of dropboxes. This gap was larger at locations with dropboxes. 
Table 4.3 Responses to multiple-choice customer survey questions at locations with and without dropboxes. In the first two questions, responses are split into safe and unsafe disposal behaviors with subtotals reported in bold for each category. Sample size differences between questions are due to exclusion of unanswered questions.

\begin{tabular}{llll}
\hline & Total \% (n) & Dropbox \% (n) & No Dropbox \% (n) \\
\hline What do you do with leftover drugs? & & & \\
Store at home & $41.7 \%(50)$ & $40.4 \%(19)$ & $42.5 \%(31)$ \\
Throw in trash & $27.5 \%(33)$ & $23.4 \%(11)$ & $30.1 \%(22)$ \\
Flush & $15.8 \%(19)$ & $14.9 \%(7)$ & $16.4 \%(12)$ \\
Unsafe Disposal & $\mathbf{8 5 . 0 \% ( 9 9 )}$ & $\mathbf{7 8 . 7 \% ( 3 7 )}$ & $\mathbf{8 9 . 0 \% ( 6 5 )}$ \\
Use a Dropbox & $8.3 \%(10)$ & $10.6 \%(5)$ & $6.8 \%(5)$ \\
Take to Police Station & $4.2 \%(5)$ & $6.4 \%(3)$ & $2.7 \%(2)$ \\
Return to pharmacy & $1.7 \%(2)$ & $4.3 \%(2)$ & $0 \%(0)$ \\
Safe Disposal & $\mathbf{1 4 . 2 \% ( 1 7 )}$ & $\mathbf{2 1 . 3 \% ( 1 0 )}$ & $\mathbf{9 . 5 \% ( 7 )}$ \\
Other & $0.8 \%(1)$ & $0 \%(0)$ & $1.4 \%(1)$
\end{tabular}

What do doctors, nurses and pharmacists recommend for drug disposal?

$\begin{array}{llll}\text { Throw in trash } & 25.6 \%(32) & 23.5 \%(12) & 27.0 \%(20) \\ \text { Flush } & 20.0 \%(25) & 11.8 \%(6) & 25.7 \%(19) \\ \text { nsafe Disposal } & \mathbf{4 5 . 6 \% ( 5 7 )} & \mathbf{3 5 . 3 \%}(\mathbf{1 8}) & \mathbf{5 2 . 7 \% ( 3 9 )} \\ \text { Use a dropbox } & 8.8 \%(11) & 15.7 \%(8) & 4.1 \%(3) \\ \text { Return to pharmacy } & 4.8 \%(6) & 7.8 \%(4) & 2.7 \%(2) \\ \text { Take to Police Station } & 0.8 \%(1) & 2.0 \%(1) & 0 \%(0) \\ \text { afe Disposal }^{\text {Never been told }}{ }^{1} & \mathbf{1 4 . 4 \% ( 1 8 )} & \mathbf{2 5 . 5 \% ( 1 3 )} & \mathbf{6 . 8 \% ( 5 )} \\ & 40.0 \%(50) & 39.2 \%(20) & 40.5 \%(30)\end{array}$

Where would you look for information regarding disposal of leftover drugs?

Online

Ask a pharmacist

Check the medicine label

Other

$\begin{array}{lll}51.6 \%(63) & 51.0 \%(25) & 51.4 \%(38) \\ 30.3 \%(37) & 22.4 \%(11) & 35.1 \%(26) \\ 18.0 \%(22) & 24.5 \%(12) & 13.5 \%(10) \\ 0.8 \%(1) & 2.0 \%(1) & 0 \%(0)\end{array}$

Do you know where the nearest dropbox is located?
No
Yes
$86.0 \%(111) \quad 76.5 \%(39)$
$14.0 \%(18) \quad 23.5 \%(12)$
$92.3 \%(72)$
$7.7 \%(6)$
What are the obstacles for you for using a

$\begin{array}{llll}\text { Until now, did not know about droboxes } & 56.0 \%(70) & 50.0 \%(25) & 60.0 \%(45) \\ \text { Take them somewhere else } & 14.4 \%(18) & 20.0 \%(10) & 10.7 \%(8) \\ \text { Usually flush drugs or throw them in the trash } 12.8 \%(16) & 10.0 \%(5) & 14.7 \%(11) \\ \text { Keep them for the future } & 8.0 \%(10) & 14.0 \%(7) & 4.0 \%(3) \\ \text { Never remember to bring them with me } & 7.2 \%(9) & 6.0 \%(3) & 8.0 \%(6) \\ \text { Other } & 1.6 \%(2) & 0 \%(0) & 2.7 \%(2)\end{array}$
dropbox?

If asked, could you explain why it matters where leftover pharmaceuticals are disposed?

$\begin{array}{llll}\text { No } & 64.1 \%(82) & 58.8 \%(30) & 67.5 \%(52) \\ \text { Yes } & 35.9 \%(46) & 41.2 \%(21) & 32.5 \%(25)\end{array}$


${ }^{1}$ Excluded from unsafe/safe disposal categorization

\subsubsection{Pharmacist Interviews}

Of the 42 pharmacists and pharmacy technicians we contacted, 29 at 25

pharmacies agreed to an interview (response rate $=69 \%$ ), eight with a dropbox and 17 without a dropbox. At four locations, we interviewed two pharmacists and at all other locations we interviewed one pharmacist ( $\mathrm{n}=9$ dropbox; $\mathrm{n}=20$ no dropbox). Pharmacists gave the following responses for recommendations to customers: using a pharmacy dropbox (onsite or at a nearby pharmacy), taking to a police station, looking at the DEA website, throwing in the trash with an undesirable substance (e.g., kitty litter, coffee grounds), contacting garbage/recycling collectors, flushing, taking to a drug take-back day, and throwing directly in the trash (Figure 4.1). Many pharmacists shared two or more ways to dispose of drugs, often including both environmentally safe and unsafe methods, such as throwing drugs in the trash and taking them to a police station $(\mathrm{n}=1)$. Two pharmacists explicitly stated disposal methods should depend on the type of drugs and recommended flushing for dangerous drugs and throwing away or saving for a collection event for others. Many pharmacists redirected customers to look elsewhere, such as the DEA website, $(n=7)$ or their local garbage collector $(n=3)$ for the answer.

At locations with dropboxes, pharmacist recommendations were more consistent and environmentally sound than at locations without dropboxes (Figure 4.1). Pharmacists with dropboxes onsite only suggested three methods for disposal: using an onsite dropbox $(89.9 \%, \mathrm{n}=8)$, contacting law enforcement $(55.6 \%, \mathrm{n}=5)$, or looking at the DEA website for instructions $(11.1 \%, \mathrm{n}=1)$. They never recommended flushing or throwing drugs in 
the trash. Except for one individual, the first recommendation given by all pharmacists at locations with dropboxes was to bring their drugs to the onsite dropbox $(n=8)$. Four pharmacists included additional recommendations of contacting the police station or looking at the DEA website, but only for liquids, sharps, and narcotics which are not accepted in these pharmacy dropboxes. One pharmacist recommended calling local law enforcement, rather than bringing drugs to the onsite dropbox. Although this one pharmacist's onsite dropbox was not the subject of their first recalled recommendation, the individual did recall the presence of the onsite dropbox when discussing employer policy for leftover drug disposal. This individual also had a positive attitude towards the dropbox indicating that the pharmacist was aware and understood its value, but could benefit from some training to commit to its use.

At locations without dropboxes, pharmacist recommendations were highly variable (Figure 4.1). The most common response was contacting or taking drugs to a police station $(55.0 \%, \mathrm{n}=11)$, followed by using a dropbox $(35.0 \%, \mathrm{n}=7)$, throwing in the trash with an undesirable substance $(30.0 \%, \mathrm{n}=6)$ and checking the DEA website $(30.0 \%$, $\mathrm{n}=6$ ). Using a dropbox was mentioned, especially by pharmacists working in the same chain of stores that had dropboxes at other locations $(20.0 \%, \mathrm{n}=4)$. Only two pharmacists (10.0\%) recommended flushing drugs and two others shared that customers should avoid flushing because drugs may enter the water system, indicating some awareness of environmental impacts of improper disposal. 


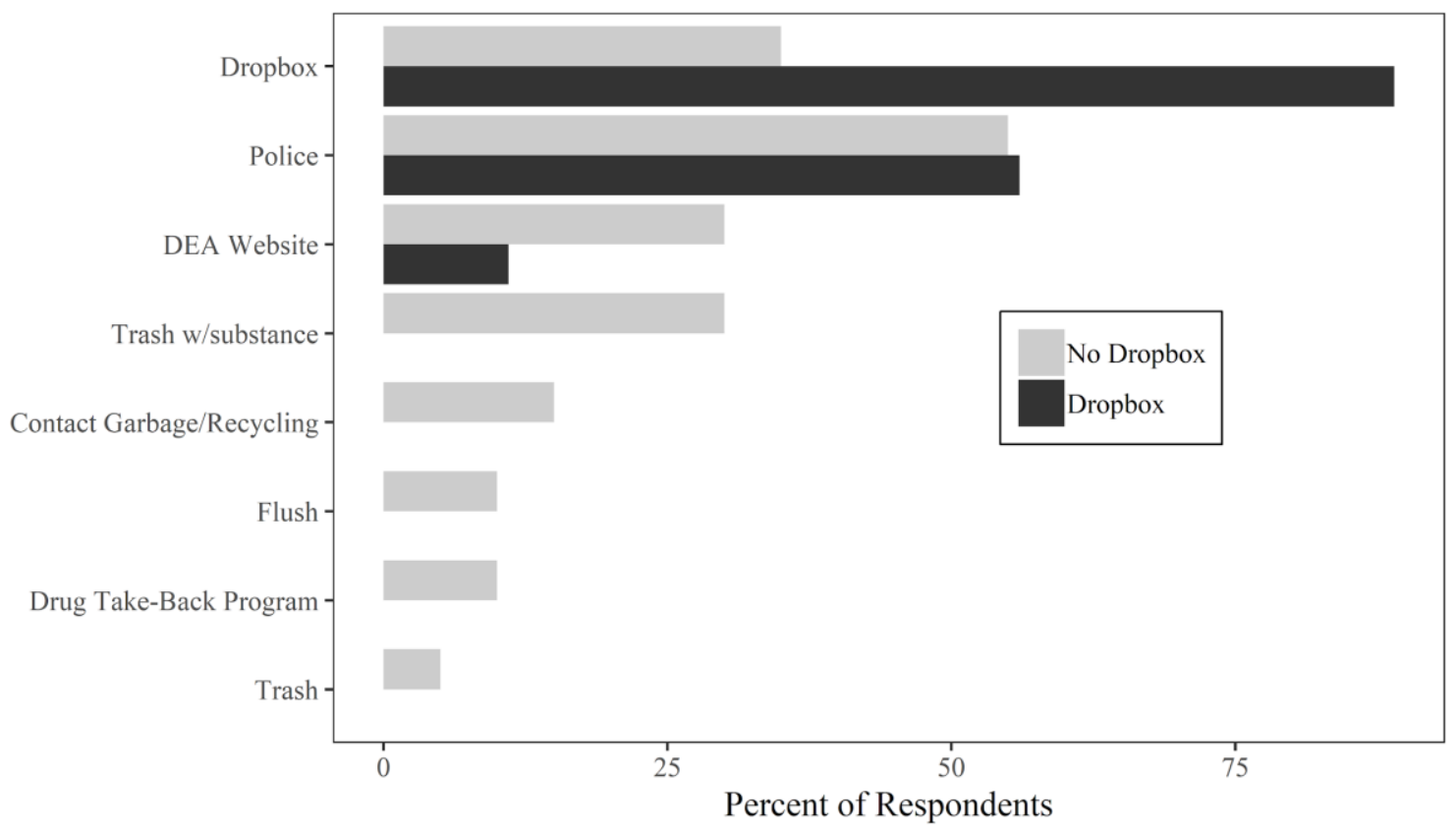

Figure 4.1 Percent of pharmacists that recommended each type of disposal method to customers at locations with $(n=9)$ and without $(n=20)$ dropboxes.

We asked pharmacists about their attitudes regarding drug take-back programs and categorized these responses into positive, neutral, and negative attitudes. If a pharmacist explicitly said that programs were "good," "great," "necessary," or another positive sentiment, this was categorized as a positive attitude. A total of 19 pharmacists $(65.5 \%)$ expressed positive attitudes. Pharmacists that either stated they had no opinion or did not express a strong positive or negative attitude were classified as a neutral attitude. A total of nine pharmacists $(31.0 \%)$ had neutral attitudes. One pharmacist $(3.4 \%)$ working at a dropbox location had a negative attitude sharing that drug take-back programs are a "hassle" and it is preferred to take drugs to a police station. All other pharmacists at dropbox locations expressed positive attitudes towards take-back programs $(n=8)$. When asked about their co-workers' attitudes toward drug take-back 
programs, most pharmacists stated that their co-workers agreed with their opinion (Appendix C1).

Pharmacists mentioned several pros and cons to drug take-back programs (Table 4.4). Three reported benefits were safety (the most common; $n=12$ ), followed by an even number of pharmacists mentioning pollution reduction $(n=2)$ and easy disposal for customers $(\mathrm{n}=2)$. Pharmacists also shared several hindrances to establishment and use of dropboxes. The most common response was cost $(n=7)$, followed by lack of public education/awareness $(n=5)$, and liability for the pharmacy $(n=3)$, among others (see Table 4.4 for full list).

Table 4.4 Pharmacist responses to open-ended phone interview question regarding pros and cons of drug take-back programs at locations with $(n=9)$ and without $(n=20)$ dropboxes.

\begin{tabular}{llll}
\hline & Total \# & Dropbox \# & No Dropbox \# \\
\hline Pros & & & \\
$\quad$ Safety & 12 & 5 & 7 \\
Reduces pollution & 2 & 1 & 1 \\
Easy disposal for customers & 2 & 1 & 1 \\
No Answer & 15 & 4 & 11 \\
& & & \\
Cons & & & \\
Cost & 7 & 2 & 5 \\
Lack of public education & 5 & 2 & 3 \\
Liability for pharmacy & 3 & 0 & 3 \\
Hassle for pharmacist/pharmacy & 2 & 1 & 1 \\
There are no cons & 2 & 1 & 1 \\
Inconsistent information from regulatory agencies & 1 & 1 & 0 \\
Cannot accept all medications & 1 & 1 & 0 \\
Inconvenient for customers & 1 & 0 & 1 \\
Requires a third party & 1 & 0 & 1 \\
Time to implement & 1 & 0 & 1 \\
Regulations & 1 & 0 & 1 \\
No Answer & 11 & 3 & 8 \\
\hline
\end{tabular}

\subsubsection{Focus Group}

With such varied information from pharmacists regarding challenges of drug takeback programs, we aimed to explore the major obstacles to dropbox implementation and 
use through discussion with individuals that held expertise in establishment or policies surrounding dropboxes in Oregon. The focus group consisted of five participants, three in person and two remotely. Participants discussed three major challenges to implementing dropboxes: cost, floor space, and policy inconsistencies. The primary issue identified was the cost of long-term maintenance of an onsite dropbox, as stores are responsible for paying a fee for each pick up, approximately \$275 in Oregon. One participant stated that when dropboxes were installed at a chain of pharmacies in Portland, OR, they were popular and heavily used, which was described as expensive to empty frequently and resulted in dropboxes being temporarily closed while waiting for dropbox servicing. This individual shared that initial setup of the box, which costs around $\$ 2,000$, was more affordable because it is a one-time fee and grant money was provided to some pharmacies to cover half the cost. Focus group participants indicated that the high costs of installation and maintenance of a dropbox and a lack of revenue for the pharmacy disincentivizes pharmacies from establishing dropboxes. Focus group participants also highlighted a need for legislation or funding opportunities to increase dropbox installation. Participants emphasized that the pharmaceutical industry should be responsible for the costs of dropbox setup and maintenance, rather than the retail pharmacies, but there is currently strong industry opposition. The participants noted that the pharmaceutical industry already collects and disposes of unsold expired drugs from the pharmacy, and therefore should already have protocols in place that could be applied to customer disposal. Floor space can present a significant problem for small stores but could be worked around if dropbox installation and disposal costs were not an issue. Policy inconsistencies in terms 
of variability in drug types and forms permissible for collection at different dropboxes can lead to contamination at dropboxes with more restrictive third-party collection policies. For example, if controlled substances (drugs that are regulated under US federal law based on medical use, potential for abuse, and safety) are found in a dropbox with restrictions on drug type (per DEA regulations; U.S. DEA 2014), that shipment of disposed drugs is considered contaminated and may not be properly disposed of.

When asked about training for pharmacists, participants shared concerns about "ignorance among pharmacists" because they are prohibited from collecting drugs, but also noted the great opportunity for improvement by adding such training to pharmacy schools. One individual was instructed at pharmacy school to mix drugs with an undesirable substance (e.g., kitty litter or coffee grounds) and throw away ten years prior to the focus group. Shifting the pharmacy school curriculum and new pharmacy employee training to focus on appropriate disposal methods could improve communication to customers. In general, participants expressed a need for better initial training and continuing education for pharmacists.

When asked about public use and awareness of dropboxes, participants said the predominant issue is a lack of dropboxes, and that increasing public awareness without more infrastructure would be problematic. One focus group participant reported dropboxes fill up within 3-7 days with little to no educational intervention. Participants shared that once a dropbox is established, its presence acts as an educational tool, and customers are likely to use it. Pamphlets, brochures, and stickers on medication bottles were discussed as options to deliver information to customers about proper disposal. 
Stickers on the medication bottle or associated materials from the pharmacy with a QR code or link were the most favorable option to focus group participants. However, it was further emphasized that a successful educational campaign would likely increase dropbox disposal beyond the capacity of current retail pharmacies; thus increased availability of dropboxes is needed before education will be useful.

One focus group participant felt strongly that state legislation requiring dropboxes in every pharmacy is needed in order to install an adequate number of dropboxes to meet the needs of consumers. Participants emphasized that the current messaging used in lobbying for legislative efforts is focused on the opioid crisis, with little information on environmental issues. Participants mentioned legislation might be more successful if the environmental perspective was added to the opioid risks information, particularly on the US West Coast where environmental issues are important to the public (Mazur and Welch 1999). This point is important as dropboxes take most drug types and therefore benefit multiple consumers, not just those concerned about opioid abuse.

\subsection{Discussion}

Customer drug disposal practices are variable and differ among pharmacies with and without dropboxes. Over a third of customers in our sample (41.7\%) are storing unused medications at home, with potential safety and environmental implications. The most common disposal methods reported by our participants were throwing in the trash (27.5\%), flushing (15.8\%), and using a dropbox (8.3\%). These rates are lower than other studies investigating customer disposal of various drug types in the United States, but this 
is likely due to the high number of customers surveyed that reported storing drugs at home. Three studies reported that $45-62 \%$ of customers throw drugs in the trash and 18$31 \%$ flush drugs down the toilet or sink, with only $12-17 \%$ never disposing or storing at home (Law et al. 2014, Wieczorkiewicz et al. 2013, Kotchen et al. 2009). These studies were published prior to legislation permitting dropboxes within pharmacies, so it is difficult to compare dropbox usage. However, $6-11 \%$ of customers in these studies reported returning drugs to a pharmacy, which is within the range of dropbox usage in our study (Law et al. 2014, Wieczorkiewicz et al. 2013, Kotchen et al. 2009). Customer disposal methods were improved at dropbox locations with more customers reporting using a dropbox, and fewer customers throwing drugs in the trash, indicating that dropbox presence may well increase proper disposal. Although we found low customer awareness of dropboxes and risks of improper disposal, awareness was greater in pharmacies with a dropbox present, supporting the idea that pharmacy dropboxes act as educational tools. The few customers that reported awareness and understanding of dropboxes but not use also reported flushing, throwing away, storing at home and forgetting to bring drugs with them to the dropbox. This shows that a marketing campaign to raise awareness and focus on intent could be useful.

Pharmacists can be an important source of information to increase proper disposal, particularly with expansion of onsite dropbox locations. Several customers reported never receiving instructions from pharmacists regarding drug disposal (40.0\%), but $30.3 \%$ said pharmacists are their preferred source of information. Hence, customer drug disposal could be improved with small educational efforts, especially directly from 
pharmacists. For example, in a study in New York, nearly $60 \%$ of surveyed pharmacy customers $(\mathrm{N}=242)$ indicated that they would change disposal behavior to a safer method following pharmacy student-facilitated education (Abrons et al. 2010). Those that reported no intention to change behavior mentioned inconvenience and a lack of takeback locations as reasons (Abrons et al. 2010). Although customer education is important, it may have limited impact until more dropboxes are established for yearround collection to provide easy access to open dropboxes (full dropboxes are 'closed' to collection until emptied).

Pharmacists gave variable recommendations for customer drug disposal, but this variability was substantially reduced at locations with dropboxes (Figure 4.1). Pharmacists at dropbox locations recommended proper disposal methods, primarily to use the onsite dropbox, and never told customers to flush or throw away drugs. This indicates pharmacy dropbox presence greatly improved pharmacist communication with their customers about leftover drug disposal. Direct educational interventions may further improve pharmacist recommendations to patients. A pre- and post-survey of 158 pharmacists in Massachusetts provided an educational brochure to pharmacists and found that this reduced recommendations to flush and wash drugs down the sink by $5 \%$ and $13 \%$ respectively, and increased knowledge of environmental impacts of improper disposal by $10 \%$ (Jarvis et al. 2009). Just over a third of these pharmacists had never learned about proper disposal of drugs (36\%), and only $19 \%$ said they learned about disposal in pharmacy school (Jarvis et al. 2009). This study demonstrated that an educational intervention increased pharmacist knowledge and changed recommendations 
(Jarvis et al. 2009), hence further initial education at pharmacy school and onboarding education for new hires at pharmacies could be a powerful driver of change. Participants in our focus group reported similar views, specifically that it is most valuable to teach pharmacists before they establish a routine by encouraging changes to pharmacy school curricula. Despite a general lack of education on drug disposal, most pharmacists are supportive of drug take-back programs and showed particularly high enthusiasm at locations with dropboxes. They recognized the benefits of take-back programs in increasing public safety but were relatively unaware of environmental concerns. Additionally, they focused less on cost, liability, and inconvenience as obstacles compared to no dropbox locations, indicating that these views are more associated with establishment of a program. Once a dropbox is established in the pharmacy, pharmacists are more supportive and informed about drug take-back, and fewer barriers are apparent.

Several major themes surrounding proper drug disposal were identified in the focus group with pharmacy professionals. The first was that dropboxes serve as important educational tools in pharmacies. Customers notice them, ask questions, and use them frequently. While changes in customer disposal based on presence of dropboxes were smaller than expected, the positive effect on pharmacist recommendations was strong. Although the predominant issue identified was a lack of dropboxes, rather than education or awareness, some useful educational methods were identified. Specifically a sticker on medication bottles was identified as a good option. In our surveys, a higher percentage of customers said they seek information online or from a pharmacist than on a medication bottle, indicating that educational interventions focused on streamlining 
online information from agencies and improving pharmacist knowledge and communication are at least as important as clear labeling on medication. The lack of reliance on medication packaging could be due to the current absence of information on pill bottles regarding disposal. Adding consistent instructions could make this a more convenient option for seeking information.

A major hindrance to dropbox adoption is cost. Options to address cost include government grants, customer fees, and the pharmaceutical industry fronting the costs. As explained by one pharmacy manager in the focus group, grants were provided in Oregon to cover $50 \%$ of the cost of establishing dropboxes, indicating that even cost shares can be effective. A California study of 1,008 people found consumers would be willing to pay approximately $\$ 1.50$ per prescription to go towards disposal, an amount that would support a year-round drug take-back program within pharmacies (Kotchen et al. 2009). There is some evidence that dropboxes could increase profit by attracting more customers that want to dispose of drugs properly. In a survey of consumer perceptions of a drug take-back program within a pharmacy, $84 \%$ of respondents said they would be more likely to choose a pharmacy offering this service and 59\% said they would be willing to pay for disposal on a per weight basis (Thach et al. 2013). Our focus group participants heavily emphasized that the pharmaceutical industry should be responsible for costs, yet we could find little evidence that the industry or the federal government currently supports this recommendation. Focus group participants felt that the lack of support is due to the industry position that excretion is the major contributor to environmental pollution and disposal is negligible. However, the documented quantities of collected 
drugs, particularly from drug take-back events, indicate a potentially large environmental impact of improper disposal. Moreover, recent studies find pharmaceutical disposal can contribute significantly to contamination of waterways. Bound and Voulvoulis (2005) used a model to evaluate excretion and disposal routes of certain drugs based on percent consumed, body metabolism, and wastewater treatment removal, and found that for drugs with low metabolic and wastewater treatment removal rates, and those for which consumers do not finish the whole prescription, disposal may contribute a similar percentage as excretion. Additionally, the concentration of hydrocodone in wastewater treatment plant effluent decreased after a drug take-back event in Texas, indicating that proper disposal has the potential to reduce pharmaceutical loadings to the environment (Stoddard and Huggett 2015). More research examining the effects of disposal on environmental contamination may be needed to convince drug distributors of the role improper disposal plays in environmental contamination.

Although our study reports findings based on a small sample size, uneven site numbers between dropbox and no dropbox pharmacies, and the short timescale since dropbox implementation, our results provide a useful understanding of our study sample and were similar to findings from other studies in the US. The few dropbox sites available resulting in uneven sampling represent the reality of an uneven distribution of dropboxes across our study area and across the US. Finally, as pharmacy dropboxes are a relatively new innovation, their long-term impacts may not yet be apparent, and our results may reflect the challenges of transitioning to pharmacy-based leftover drug disposal. Despite these limitations, this study provides useful information as the first 
research to evaluate effects of dropbox presence on customers and pharmacists. We recommend that future studies seek to validate our findings with larger samples over a longer term as dropboxes become more prominent in retail pharmacies. Additionally, future studies could benefit from asking pharmacists how drug take-back programs could be improved and including customer questions to assess factors that limit use of dropboxes among those who are aware of but don't use dropboxes.

\subsection{Conclusion}

Our findings indicate high rates of drug storage and an overall lack of awareness of dropboxes among customers, with high variation in leftover drug disposal recommendations by pharmacists, particularly at pharmacies without dropboxes. The presence of a dropbox at a pharmacy was associated with greater customer awareness of proper drug disposal and safer pharmacist recommendations to customers. These findings support the value of legislative efforts to increase the number of established dropboxes at pharmacies in Oregon and throughout the country. Based on feedback from customers, pharmacists, and other pharmacy professionals, we recommend: (1) further efforts focus on the increased establishment of dropboxes in pharmacies, (2) development of pharmacy school and employment training programs on appropriate drug disposal that include communication recommendations for pharmacists to patients, (3) changes to online information from federal and local agencies to improve consistency, and (4) addition of safe disposal information on medication bottles. 


\subsection{Acknowledgements}

We thank the customers, pharmacists and professionals that participated in our surveys, interviews, and focus group. We also thank A. Lubitow for input on data presentation and manuscript framing. This work was supported by the Portland State University Institute for Sustainable Solutions with a grant awarded to EFG and MNP. We appreciate comments from two anonymous reviewers and the journal Associate Editor that helped improve the manuscript.

\subsection{References}

Aitken, M. 2016. Medicines use and spending in the U.S. A review of 2015 and outlook to 2020. IMS Institute for Healthcare Informatics. Available: https://morningconsult.com/wp-content/uploads/2016/04/IMS-Institute-US-DrugSpending-2015.pdf [accessed 30 August 2019].

Abahussain EA, Ball DE, Matowe WC. 2006. Practice and Opinion towards Disposal of Unused Medication in Kuwait. Medical Principles and Practice 15:352-357; doi: $10.1159 / 000094268$.

Abrons J, Vadala T, Miller S, Cerulli J. 2010. Encouraging safe medication disposal through student pharmacist intervention. Journal of the American Pharmacists Association 50:169-173; doi:10.1331/JAPhA.2010.09208.

Arpin-Pont L, Bueno MJM, Gomez E, Fenet H. 2016. Occurrence of PPCPs in the marine environment: a review. Environmental Science and Pollution Research 23:4978-4991; doi:10.1007/s11356-014-3617-X. 
Bound JP, Voulvoulis N. 2005. Household Disposal of Pharmaceuticals as a Pathway for Aquatic Contamination in the United Kingdom. Environmental Health Perspectives 113:1705-1711; doi:10.1289/ehp.8315.

Daughton CG, Ruhoy IS. 2009. Environmental footprint of pharmaceuticals: the significance of factors beyond direct excretion to sewers. Environ Toxicol Chem 28:2495-2521; doi:10.1897/08-382.1.

Daughton CG, Ternes TA. 1999. Pharmaceuticals and personal care products in the environment: agents of subtle change? Environmental Health Perspectives 107: 907-938; doi:10.1289/ehp.99107s6907

Fent K, Weston AA, Caminada D. 2006. Ecotoxicology of human pharmaceuticals. Aquatic Toxicology 76:122-159; doi:10.1016/j.aquatox.2005.09.009.

Gaw S, Thomas KV, Hutchinson TH. 2014. Sources, impacts and trends of pharmaceuticals in the marine and coastal environment. Philosophical Transactions of the Royal Society B: Biological Sciences 369:20130572-20130572; doi:10.1098/rstb.2013.0572.

Hughes SR, Kay P, Brown LE. 2013. Global Synthesis and Critical Evaluation of Pharmaceutical Data Sets Collected from River Systems. Environmental Science \& Technology 47:661-677; doi:10.1021/es3030148.

Jarvis CI, Seed SM, Silva M, Sullivan KM. 2009. Educational campaign for proper medication disposal. Journal of the American Pharmacists Association 49:65-68; doi:10.1331/JAPhA.2009.08032. 
Jones OAH, Voulvoulis N, Lester JN. 2005. Human Pharmaceuticals in Wastewater Treatment Processes. Critical Reviews in Environmental Science and Technology 35:401-427; doi:10.1080/10643380590956966.

Kotchen M, Kallaos J, Wheeler K, Wong C, Zahller M. 2009. Pharmaceuticals in wastewater: Behavior, preferences, and willingness to pay for a disposal program. Journal of Environmental Management 90:1476-1482; doi:10.1016/j.jenvman.2008.10.002.

Kümmerer K. 2010. Pharmaceuticals in the Environment. Annual Review of Environment and Resources 35:57-75; doi:10.1146/annurev-environ-052809161223.

Kusturica MP, Sabo A, Tomic Z, Horvat O, Šolak Z. 2012. Storage and disposal of unused medications: knowledge, behavior, and attitudes among Serbian people. International Journal of Clinical Pharmacy 34:604-610; doi:10.1007/s11096-012$\underline{9652-0 .}$

Law AV, Sakharkar P, Zargarzadeh A, Tai BWB, Hess K, Hata M, et al. 2015. Taking stock of medication wastage: Unused medications in US households. Research in Social and Administrative Pharmacy 11:571-578; doi:10.1016/j.sapharm.2014.10.003.

Lubick, N. 2010. Drugs in the Environment: Do Pharmaceutical Take-Back Programs Make a Difference? Environmental Health Perspectives 118:A210-A214; doi:10.1289/ehp.118-a210. 
Martin, K. 2019. DEA's 17th National Prescription Drug Take Back Day has highestever partner participation. Available: https://www.dea.gov/press$\underline{\text { releases/2019/05/06/deas-17th-national-prescription-drug-take-back-day-has- }}$ highest-ever [accessed 30 August 2019].

Mazur A, Welch EW. 1999. The geography of American environmentalism. Environmental Science \& Policy 2:389-396; doi:10.1016/S1462-9011(99)00033-7. Meador JP, Yeh A, Young G, Gallagher EP. 2016. Contaminants of emerging concern in a large temperate estuary. Environmental Pollution 213:254-267; doi:10.1016/j.envpol.2016.01.088.

Office of Management and Budget (OMB). 2006. Update of Statistical Area Definitions and Guidance on Their Uses. Available: https://www.whitehouse.gov/sites/whitehouse.gov/files/omb/bulletins/20012008/b07-01.pdf [accessesd 15 October 2019]

Oregon Health Authority. N.D. Drug Take-Back and Disposal: Groundwater \& Source Water Protection: State of Oregon. Available:https://www.oregon.gov/oha/PH/HEALTHYENVIRONMENTS/DRINKI NGWATER/SOURCEWATER/Pages/takeback.aspx [accessed 22 April 2019].

Peters JR, Granek EF. 2016. Long-term exposure to fluoxetine reduces growth and reproductive potential in the dominant rocky intertidal mussel, Mytilus californianus. Science of The Total Environment 545-546:621-628; doi:10.1016/j.scitotenv.2015.12.118. 
Ruhoy IS, Daughton CG. 2007. Types and quantities of leftover drugs entering the environment via disposal to sewage - Revealed by coroner records. Science of The Total Environment 388:137-148; doi:10.1016/j.scitotenv.2007.08.013.

Seehusen DA, Edwards J. 2006. Patient Practices and Beliefs Concerning Disposal of Medications. J Am Board Fam Med 19:542-547; doi:10.3122/jabfm.19.6.542.

Singleton J, Nissen L, Barter N, McIntosh M. 2014. The global public health issue of pharmaceutical waste: what role for pharmacists? Journal of Global Responsibility 5:126-137; doi:10.1108/JGR-03-2014-0009.

Slack RJ, Gronow JR, Voulvoulis N. 2005. Household hazardous waste in municipal landfills: contaminants in leachate. Science of The Total Environment 337:119-137; doi:10.1016/j.scitotenv.2004.07.002.

Stewart H, Malinowski A, Ochs L, Jaramillo J, McCall K, Sullivan M. 2014. Inside Maine's Medicine Cabinet: Findings From the Drug Enforcement Administration's Medication Take-Back Events. American Journal of Public Health 105:e65-e71; doi:10.2105/AJPH.2014.302207.

Stoddard KI, Huggett DB. 2015. Wastewater Effluent Hydrocodone Concentrations as an Indicator of Drug Disposal Program Success. Bulletin of Environmental Contamination and Toxicology; New York 95:139-144; doi:http://dx.doi.org/10.1007/s00128-015-1574-9.

Tai B-WB, Hata M, Wu S, Frausto S, Law AV. 2016. Prediction of pharmacist intention to provide medication disposal education using the theory of planned behaviour. Journal of Evaluation in Clinical Practice 22:653-661; doi:10.1111/jep.12511. 
Teixeira JR, Granek EF. 2017. Effects of environmentally-relevant antibiotic mixtures on marine microalgal growth. Science of The Total Environment 580:43-49; doi:10.1016/j.scitotenv.2016.11.207.

Thach AV, Brown CM, Pope N. 2013. Consumer perceptions about a community pharmacy-based medication take back program. Journal of Environmental Management 127:23-27; doi:10.1016/j.jenvman.2013.04.025.

U.S. Census Bureau. 2018. American Community Survey 1-year estimates Census Reporter Profile page for Portland-Vancouver-Hillsboro, OR-WA Metro Area. Available: http://censusreporter.org/profiles/31000US38900-portland-vancouverhillsboro-or-wa-metro-area/ [accessed 15 October 2019].

U.S. Drug Enforcement Administration (DEA). N.D. (a). Drug Disposal Information. Available: https://www.deadiversion.usdoj.gov/drug_disposal/ [accessed 22 April 2019].

U.S. Drug Enforcement Administration (DEA). N.D. (b). Controlled Substance Public Disposal

Locations. Available: https://apps2.deadiversion.usdoj.gov/pubdispsearch/spring/ma in?execution=e1s1 [accessed 22 April 2019]

U.S. Drug Enforcement Administration (DEA). 2014. Disposal Regulations: Registrant Fact Sheet. Available: https://www.deadiversion.usdoj.gov/drug_disposal/fact_sheets/dis posal_registrant.pdf [accessed 13 September 2019] 
U.S. Environmental Protection Agency (EPA). 2015. Collecting and Disposing of Unwanted Medicines. Available: https://www.epa.gov/hwgenerators/collecting-anddisposing-unwanted-medicines [accessed 30 August 2019].

U.S. Food and Drug Administration (FDA) Center for Drug Evaluation and Research (CDER). 2017. New Drug Therapy Approvals. Available: https://www.fda.gov/media/110526/download [accessed 13 September 2019]

U.S. Food and Drug Administration (FDA). 2018. Development \& Approval Process (Drugs). FDA. Available: http://www.fda.gov/drugs/development-approval-processdrugs [accessed 2 August 2019]

U.S. Food and Drug Administration (FDA). 2019. Where and How to Dispose of Unused Medicines. Available: https://www.fda.gov/consumers/consumer-updates/whereand-how-dispose-unused-medicines [accessed 30 August 2019]

Vidal-Dorsch DE, Bay SM, Maruya K, Snyder SA, Trenholm RA, Vanderford BJ. 2012. Contaminants of emerging concern in municipal wastewater effluents and marine receiving water. Environmental Toxicology \& Chemistry 31:2674-2682; doi:10.1002/etc.2004.

Vieno N, Tuhkanen T, Kronberg L. 2007. Elimination of pharmaceuticals in sewage treatment plants in Finland. Water Research 41:1001-1012; doi:10.1016/j.watres.2006.12.017.

Walgreens. 2019. Safe medication disposal. Available: https://www.walgreens.com/topic/ pharmacy/safe-medication-disposal.jsp [accessed 22 October 2019]. 
Wieczorkiewicz SM, Kassamali Z, Danziger LH. 2013. Behind Closed Doors:

Medication Storage and Disposal in the Home. Ann Pharmacother 47:482-489; doi:10.1345/aph.1R706. 


\section{Chapter 5: Conclusion}

Marine ecosystems face challenges of multiple stressors, many of which have the potential to interact, and upend delicate ecological interactions that allow these systems to thrive. The ocean provides abundant resources to humans, including food, oxygen, and climate regulation, and is essential to human life. Understanding the impacts of anthropogenic pollution on marine ecosystems is important for managing and conserving these diverse and valuable places. Many marine contaminants are invisible, difficult to measure, and come with huge challenges in identifying long-term impacts. PPCPs and other emerging contaminants are present in our oceans, yet little is known about their effects on organisms, communities, and ecological interactions. Additionally, remediation options, such as WWTP improvements, are expensive, impractical, and/or require more data to inform appropriate methods. In my dissertation research, I set out to fill some of the gaps in quantifying PPCPs in marine environments, identifying effects on commercially important species, and exploring a possible remediation opportunity.

\section{Summary of Research Findings}

In chapter 2, I conducted a field experiment in which Pacific oysters were transplanted to sites near WWTP outfalls and aquaculture to compare bioaccumulation and health effects. I found that Pacific oysters accumulated PPCPs in OR and WA estuaries, at sites near and far from wastewater sources, including areas where they are being commercially produced. Distance to WWTP outfalls did not drive variation at a small spatial scale, though pharmaceutical detections were more frequent at wastewater 
sites compared to oyster growout sites. In chapter 3, I exposed oysters directly to effluent from coastal WWTPs in a lab experiment to evaluate organismal effects and uptake, and quantify PPCP levels in effluent. I found that oysters experienced more PPCP uptake in the lab when exposed directly to WWTP effluent, compared to the field. An array of PPCPs were detected in effluent from two small coastal wastewater treatment plants, adding to the body of literature on occurrence in effluent and providing concentration ranges from less populated regions. Effluent and tissue detections support other research showing that PPCP contamination is ubiquitous, even in areas with low development. Overall, concentrations of PPCPs in tissue and effluent were lower than previously published ranges, which makes sense given the lack of urbanization, small surrounding populations, and associated usage patterns.

Based on examination of growth, health, and feeding rates in the field and lab, exposures to these toxins resulted in a few detectable effects on oysters at the organism level. In the field, oysters transplanted to aquaculture sites had higher condition index than those near wastewater. In the lab, oysters exposed to effluent from one WWTP $(<1$ mgd discharge capacity) had slower shell growth rates and higher feeding rates (10\% effluent exposure only). These results suggest that even at low, environmentally relevant concentrations, PPCP mixtures have some subtle effects on oysters. I found that the different concentrations of effluent did not drive these differences and expected more effects to be present following effluent exposure. To explain the lack of effects on oysters, I have three hypotheses: 1) oysters are less sensitive to pollutants; 2) effects were not detectable at the organism level, but may be present at lower biological levels (e.g., 
molecular, cellular, tissue, organ), and 3) stress induced by the tank environment overshadowed concentration level effects. Prior research supports these hypotheses and it is possible that all contributed to the results. Pacific oysters can thrive in variable environmental conditions and Oregon estuaries are relatively pristine compared to those on the U.S. East and South coasts. Additionally, previous experiments examining pollution effects on Pacific oysters tend to detect effects at lower biological levels more often than at the organism level (e.g., (Mottier et al. 2015; Akcha et al. 2016).

In chapter 4, I conducted surveys with pharmacy customers and interviews with pharmacists about drug disposal practices and recommendations. Drug disposal may be a prominent route of pharmaceuticals to the environment and improving disposal practices is a practical method to reduce loadings from this source. Customer surveys revealed that most consumers store leftover drugs at home and have low awareness of drug take-back boxes. Pharmacist recommendations for drug disposal were highly variable, but were substantially more consistent and safer at locations with established drug take-back boxes. Additionally, customer use of dropboxes was marginally improved at these locations. Federal recommendations for disposal continue to include throwing away, flushing, and saving for a take-back event which pose risks to public health and the environment. My research findings indicate that establishment of drug take-back boxes in a majority of pharmacies in Oregon, and eventually the country, is a promising path to improve drug disposal practices. This issue is of importance to local communities and in 2019, the OR legislature passed a bill to establish a drug manufacturer funded drug take back program in the state by summer of 2021 (OR DEQ 2020). 


\section{Future Research Directions}

Future research on PPCP occurrence, effects, and remediation could expand on the findings of this dissertation in several ways. Organism transplantation and collection from the wild is important to document detections and concentrations for contaminant monitoring. In future transplant studies, I would recommend measuring multiple sample matrices (e.g., sediment, seawater, and tissue concentrations) at each site to improve the ability to detect and quantify PPCPs with varying chemical properties. This may also elucidate exposure routes when tissue detections are low and allow for clearer conclusions about whether or not organisms are exposed even if they are not accumulating toxins. Lab experiments that address mixtures of PPCPs and examine environmentally relevant effects are necessary to identify toxicity of these compounds to sensitive organisms and ecosystem processes. I recommend that these studies include as many biological levels as possible (spanning DNA to whole organism), and take the time to explain the significance of observed effects to management and policy decision makers. Previous toxicological studies that examine cellular and subcellular endpoints often fail to highlight the significance of their findings at organism, population, and ecosystem levels. Partnerships among biologists, toxicologists, and ecologists and environmental managers could facilitate better identification and communication of large-scale impacts. Toxicity experiments can be expanded to include the effects of multiple stressors and how other major ocean changes (e.g., ocean acidification, elevated temperature, eutrophication, etc.) interact with PPCPs. These stressors are occurring 
simultaneously and therefore should be evaluated in tandem for major management decisions. The potential human health effects of consuming small amounts of PPCPs in seafood remain unknown. Examining human exposure through consumption, potential effects, and setting safe consumption standards should be priorities for future work. Lastly, drug take-back boxes may reduce pharmaceutical loadings from disposal routes and their effectiveness should be evaluated on a larger scale as they become more established in communities.

\section{Remediation Options and Recommendations}

PPCPs have received little recognition as pollutants from regulators and the public and are typically not considered a predominant stressor in aquatic and coastal ecosystems. While PPCPs are unlikely to cause immediate and substantial damage, they present a potential long term threat to ecosystem health (Richmond et al. 2017). Despite the limited number of studies documenting the occurrence of PPCPs, especially in developing countries and coastal areas with lower populations, their occurrence appears to be widespread in aquatic and marine systems. Few other compounds are used and discharged year-round, regardless of season or rain events, and have such low removal rates from WWTPs. This continual deposition into marine ecosystems at low concentrations may be having subtle, largely undetected chronic effects on wildlife. Challenges are abundant in revealing and describing these impacts due to a lack of acute toxic effects, possible synergistic and antagonistic effects from exposure to multiple compounds, and the potential for effects to occur over multiple generations. These 
impacts are difficult to observe and measure and may be overshadowed by impacts from other prominent stressors (e.g., climate change, habitat loss, fisheries) that are more apparent.

Several options may be considered for reduction of PPCP loadings to aquatic and marine environments. Pharmaceutical use and production are increasing and regulations are not limiting this growth. Therefore, with excretion of drugs as a major contributor to loadings in wastewater, changes to prescription practices and drug formulation may be beneficial. For example, Daughton and Ruhoy (2013) recommend implementation of environmentally sustainable prescription practices, which includes prescribing lower doses of certain drugs, choosing drug types that are more likely to biodegrade, and considering the duration of treatment. There are a few known drugs that deliver the desired therapeutic response at a lower dose, but information is limited and most physicians don't have consistent access to data from clinical trials (Daughton and Ruhoy 2013). More research is needed to identify lower doses that are effective, along with data access for physicians, and continued physician education on the advantages of sustainable prescription practices (Daughton and Ruhoy 2013; Klatte et al. 2017). Another important change to prescribing practices is reduction of unnecessary antibiotic prescriptions in humans, and only as necessary use in agriculture (Klatte et al. 2017).

Many currently available pharmaceuticals are relatively stable during metabolism and wastewater treatment, but recent research shows that innovative drug development could produce pharmaceuticals that readily degrade. For example, (Kümmerer 2019) used three design approaches to improve the biodegradability of three common pharmaceutical 
classes, beta-blockers, antibiotics, and a cytotoxic. Development of these "Green Pharmaceuticals" that are pharmacologically potent, but environmentally benign, could result in reduced pharmaceutical loadings, but will require incentives for the pharmaceutical manufacturers to participate (Straub 2016). Improvements to wastewater treatment technology, and upgrades to tertiary treatment would improve the removal of PPCPs by wastewater treatment plants, but may be impractical with associated costs.

While excretion is likely the prominent contributor to environmental pollution, disposed drugs should not be overlooked as an influential source. Pharmaceutical presence in the environment could be reduced with implementation of drug take-back boxes in more pharmacies and additional education such as drug disposal training for pharmacists during pharmacy school and stickers on medicine bottles with disposal instructions. For personal care and cleaning products with alkylphenols, cultural changes that lead to reductions in public usage patterns will be essential. This would require increasing public awareness about presence and potential effects of chemicals in products, encouraging use of fewer personal care products, and education about purchasing household products that contain non-toxic compounds. Unfortunately, many labels on household products do not list ingredients, which presents challenges for consumers trying to make informed choices. The EPA has begun to address this issue by implementing a "safer choice" label, mainly on detergents, soaps, and cleaners, to indicate that the product does not contain environmentally harmful ingredients, including alkylphenols (US EPA 2020). More transparent labeling on a variety of products, combined with education about potential harm to humans and the environment could 
reduce consumer use of certain products. Educational campaigns could be led by scientists and environmental organizations/groups to target consumers. Overall, remediation and reduction of PPCPs in the environment will require a combination of implementation of best practices regarding drug prescription and use, improved consumer choices, and legislation to support better product labeling, proper drug disposal, and when feasible, improvements to wastewater treatment. Implementing and improving these interventions will require continued research from ecological, toxicological, social, and human health perspectives to determine if actions are having an impact on prescribing practices, consumer behaviors, and pollution reduction.

\subsection{References}

Akcha F, Barranger A, Bachère E, Berthelin CH, Piquemal D, Alonso P, et al. 2016. Effects of an environmentally relevant concentration of diuron on oyster genitors during gametogenesis: responses of early molecular and cellular markers and physiological impacts. Environ Sci Pollut Res 23:8008-8020; doi:10.1007/s11356-015-5969-2.

Daughton C, Ruhoy I. 2013. Lower-dose prescribing: Minimizing "side effects" of pharmaceuticals on society and the environment. Science of The Total Environment 443:324-337; doi:10.1016/j.scitotenv.2012.10.092.

Klatte S, Schaefer H-C, Hempel M. 2017. Pharmaceuticals in the environment - A short review on options to minimize the exposure of humans, animals and ecosystems. Sustainable Chemistry and Pharmacy 5:61-66; doi:10.1016/j.scp.2016.07.001. 
Kümmerer K. 2019. From a problem to a business opportunity-design of pharmaceuticals for environmental biodegradability. Sustainable Chemistry and Pharmacy 12:100136; doi:10.1016/j.scp.2019.100136.

Mottier A, Séguin A, Devos A, Pabic CL, Voiseux C, Lebel JM, et al. 2015. Effects of subchronic exposure to glyphosate in juvenile oysters (Crassostrea gigas): From molecular to individual levels. Marine Pollution Bulletin 95:665-677; doi:10.1016/j.marpolbul.2014.10.026.

OR DEQ. 2020. State of Oregon: Rulemaking - Drug Take-Back Program 2020. Available: https://www.oregon.gov/deq/Regulations/rulemaking/Pages/rdrugtakeback2020.a spx [accessed 20 October 2020].

Richmond EK, Grace MR, Kelly JJ, Reisinger AJ, Rosi EJ, Walters DM. 2017. Pharmaceuticals and personal care products (PPCPs) are ecological disrupting compounds (EcoDC). Elem Sci Anth 5:66; doi:10.1525/elementa.252.

Straub JO. 2016. Reduction in the environmental exposure of pharmaceuticals through diagnostics, Personalised Healthcare and other approaches. A mini review and discussion paper. Sustainable Chemistry and Pharmacy 3:1-7; doi:10.1016/j.scp.2015.12.001.

US EPA. 2020. Learn About the Safer Choice Label. US EPA. Available: https://www.epa.gov/saferchoice/learn-about-safer-choice-label [accessed 29 October 2020]. 


\section{Appendix A: Supporting tables, figures, and information for chapter 2}

Table A1. Shell height and length for 1 bag of oysters from each rack collected in April 2017. Oysters were transplanted for 9 months at wastewater sites (Coos, North Bend) and oyster growout sites (Westport, Netarts, Valino Island). Distance from the nearest wastewater treatment plant outfall is listed in meters for each oyster rack at the wastewater sites.

\begin{tabular}{llllll}
\hline Site & Rack & $\begin{array}{l}\text { Distance to } \\
\text { WWTP } \\
\text { Outfall }(\mathbf{m})\end{array}$ & $\begin{array}{l}\text { Oyster } \\
\text { Count } \\
\text { bag) }\end{array}$ & $\begin{array}{l}\text { Avg Shell Height } \\
(\mathbf{m m})(\mathbf{S D})\end{array}$ & $\begin{array}{l}\text { Avg Shell } \\
\text { Length (mm) } \\
\text { (SD) }\end{array}$ \\
\hline Coos Bay & COOSa & $250 \mathrm{~m}$ & 181 & $37.17(12.09)$ & $25.21(8.04)$ \\
Coos Bay & COOSb & $750 \mathrm{~m}$ & 151 & $36.62(10.92)$ & $26.59(7.56)$ \\
Coos Bay & COOSc & $1,500 \mathrm{~m}$ & 301 & $30.02(9.05)$ & $21.82(6.15)$ \\
North Bend & NBc & 245 & 71 & $34.08(10.21)$ & $24.07(6.63)$ \\
North Bend & NBb & 265 & 55 & $37.54(10.38)$ & $26.30(5.98)$ \\
North Bend & NBa & 465 & 125 & $30.92(10.12)$ & $23.34(9.02)$ \\
North Bend & NBd & 480 & 184 & $34.67(11.09)$ & $23.57(8.51)$ \\
Valino Island & VALa & N/A & 144 & $41.63(12.73)$ & $27.65(7.59)$ \\
Valino Island & VALb & N/A & 189 & $40.38(14.99)$ & $24.18(9.41)$ \\
Valino Island & VALc & N/A & 145 & $43.87(13.01)$ & $30.05(9.12)$ \\
Netarts Bay & NETa & N/A & 202 & $35.54(9.45)$ & $25.36(6.63)$ \\
Netarts Bay & NETb & N/A & 224 & $37.49(12.15)$ & $24.70(7.34)$ \\
Netarts Bay & NETc & N/A & 208 & $29.69(8.08)$ & $20.88(5.98)$ \\
Westport & WESTa & N/A & 402 & $32.91(8.96)$ & $21.96(6.13)$ \\
Westport & WESTb & N/A & 340 & $35.04(8.63)$ & $23.15(6.30)$ \\
\hline
\end{tabular}

Table A2. Shell dimensions (height, length, width) for two bags of oysters from each rack collected in July 2017. Oysters were transplanted for 1 year at wastewater sites (Coos, North Bend) and oyster growout sites (Westport, Netarts, Valino Island). Distance from the nearest wastewater treatment plant outfall is listed in meters for each oyster rack at the wastewater sites.

\begin{tabular}{|c|c|c|c|c|c|c|c|c|}
\hline Site & Rack & Bag & $\begin{array}{l}\text { Distance to } \\
\text { WWTP } \\
\text { Outfall } \\
\text { (m) }\end{array}$ & $\begin{array}{l}\text { Oyster } \\
\text { Count }\end{array}$ & $\begin{array}{l}\text { Avg } \\
\text { Shell } \\
\text { Height } \\
\text { (mm) } \\
\text { (SD) }\end{array}$ & $\begin{array}{l}\text { Avg } \\
\text { Shell } \\
\text { Length } \\
\text { (mm) } \\
\text { (SD) }\end{array}$ & $\begin{array}{l}\text { Avg } \\
\text { Shell } \\
\text { Width } \\
\text { (mm) } \\
\text { (SD) }\end{array}$ & $\begin{array}{l}\text { Avg } \\
\text { Whole } \\
\text { Mass } \\
\text { (g) } \\
\text { (SD) }\end{array}$ \\
\hline Coos Bay & COOSa & Bag 1 & 250 & 303 & $\begin{array}{l}41.05 \\
(13.04)\end{array}$ & $\begin{array}{l}31.4 \\
(10.17)\end{array}$ & $\begin{array}{l}11.77 \\
(3.34)\end{array}$ & $\begin{array}{l}9.53 \\
(4.99)\end{array}$ \\
\hline Coos Bay & COOSa & Bag 2 & 250 & 183 & $\begin{array}{l}46.9 \\
(13.19)\end{array}$ & $\begin{array}{l}35.91 \\
(8.79)\end{array}$ & $\begin{array}{l}14.38 \\
(3.79)\end{array}$ & $\begin{array}{l}11.3 \\
(5.69)\end{array}$ \\
\hline Coos Bay & $\mathrm{COOSb}$ & Bag 1 & 750 & 203 & $\begin{array}{l}44.5 \\
(13.7)\end{array}$ & $\begin{array}{l}33.23 \\
(12.04)\end{array}$ & $\begin{array}{l}12.38 \\
(3.98)\end{array}$ & $\begin{array}{l}12.12 \\
(6.7)\end{array}$ \\
\hline Coos Bay & $\mathrm{COOSb}$ & Bag 2 & 750 & 406 & $\begin{array}{l}50.6 \\
(11.94)\end{array}$ & $\begin{array}{l}35.08 \\
(9.26)\end{array}$ & $\begin{array}{l}15.4 \\
(3.87)\end{array}$ & $\begin{array}{l}13.35 \\
(6.55)\end{array}$ \\
\hline North Bend & $\mathrm{NBc}$ & Bag 1 & 245 & 95 & $\begin{array}{l}42.52 \\
(13.71)\end{array}$ & $\begin{array}{l}33.56 \\
(10.81)\end{array}$ & $\begin{array}{l}14.06 \\
(4.22)\end{array}$ & $\begin{array}{l}12.9 \\
(8.83)\end{array}$ \\
\hline North Bend & $\mathrm{NBc}$ & Bag 2 & 245 & 47 & $\begin{array}{l}45 \\
(10.16)\end{array}$ & $\begin{array}{l}39.88 \\
(12.6) \\
\end{array}$ & $\begin{array}{l}12.16 \\
(2.93) \\
\end{array}$ & $\begin{array}{l}16.18 \\
(8.12) \\
\end{array}$ \\
\hline
\end{tabular}




\begin{tabular}{|c|c|c|c|c|c|c|c|c|}
\hline North Bend & $\mathrm{NBb}$ & Bag 1 & 265 & 51 & $\begin{array}{l}40.54 \\
(9.19)\end{array}$ & $\begin{array}{l}32.23 \\
(9.36)\end{array}$ & $\begin{array}{l}10.36 \\
(3.02)\end{array}$ & $\begin{array}{l}10.71 \\
(4.91)\end{array}$ \\
\hline North Bend & $\mathrm{NBb}$ & Bag 2 & 265 & 111 & $\begin{array}{l}38.76 \\
(10.84)\end{array}$ & $\begin{array}{l}30.32 \\
(9.44)\end{array}$ & $\begin{array}{l}13.2 \\
(4.15)\end{array}$ & $\begin{array}{l}9.97 \\
(5.32)\end{array}$ \\
\hline North Bend & $\mathrm{Nba}$ & Bag 1 & 465 & 71 & $\begin{array}{l}47.96 \\
(13.65)\end{array}$ & $\begin{array}{l}37.5 \\
(10.95)\end{array}$ & $\begin{array}{l}13.51 \\
(4.33)\end{array}$ & $\begin{array}{l}14.67 \\
(8.63)\end{array}$ \\
\hline North Bend & $\mathrm{Nba}$ & Bag 2 & 465 & 155 & $\begin{array}{l}41.56 \\
(12.77)\end{array}$ & $\begin{array}{l}28.19 \\
(7.8)\end{array}$ & $\begin{array}{l}12.26 \\
(3.55)\end{array}$ & $\begin{array}{l}11.31 \\
(7.66)\end{array}$ \\
\hline North Bend & NBd & Bag 1 & 480 & 115 & $\begin{array}{l}42.28 \\
(12.17)\end{array}$ & $\begin{array}{l}34.07 \\
(11.39)\end{array}$ & $\begin{array}{l}11.8 \\
(3.98)\end{array}$ & $\begin{array}{l}11.31 \\
(6.94)\end{array}$ \\
\hline North Bend & NBd & Bag 2 & 480 & 83 & $\begin{array}{l}43.86 \\
(13.38)\end{array}$ & $\begin{array}{l}33.72 \\
(8.54)\end{array}$ & $\begin{array}{l}10.61 \\
(3.12)\end{array}$ & $\begin{array}{l}12.55 \\
(6.39)\end{array}$ \\
\hline Netarts Bay & NETa & Bag 1 & N/A & 201 & $\begin{array}{l}44.41 \\
(13.1)\end{array}$ & $\begin{array}{l}31.34 \\
(9.06)\end{array}$ & $\begin{array}{l}11.84 \\
(4.23)\end{array}$ & $\begin{array}{l}12.7 \\
(7.58)\end{array}$ \\
\hline Netarts Bay & NETa & Bag 2 & N/A & 220 & $\begin{array}{l}42.4 \\
(9.53)\end{array}$ & $\begin{array}{l}30.45 \\
(9.18)\end{array}$ & $\begin{array}{l}11.74 \\
(3.8)\end{array}$ & $\begin{array}{l}11.46 \\
(10.85)\end{array}$ \\
\hline Netarts Bay & $\mathrm{NETb}$ & Bag 1 & N/A & 183 & $\begin{array}{l}44.79 \\
(12.8)\end{array}$ & $\begin{array}{l}33.09 \\
(9.36)\end{array}$ & $\begin{array}{l}12.76 \\
(4.62)\end{array}$ & $\begin{array}{l}13.59 \\
(7.58)\end{array}$ \\
\hline Netarts Bay & $\mathrm{NETb}$ & Bag 2 & N/A & 288 & $\begin{array}{l}44.34 \\
(12.6)\end{array}$ & $\begin{array}{l}28.61 \\
(7.61)\end{array}$ & $\begin{array}{l}13.16 \\
(3.81)\end{array}$ & $\begin{array}{l}13.21 \\
(7.57)\end{array}$ \\
\hline Netarts Bay & NETc & Bag 1 & N/A & 148 & $\begin{array}{l}41.39 \\
(10.74)\end{array}$ & $\begin{array}{l}30.63 \\
(6.88)\end{array}$ & $\begin{array}{l}10.47 \\
(2.38)\end{array}$ & $\begin{array}{l}9.56 \\
(4.44)\end{array}$ \\
\hline Netarts Bay & NETc & Bag 2 & N/A & 183 & $\begin{array}{l}36.89 \\
(10.6)\end{array}$ & $\begin{array}{l}29.51 \\
(9.73)\end{array}$ & $\begin{array}{l}10.26 \\
(2.94)\end{array}$ & $\begin{array}{l}7.88 \\
(4.12)\end{array}$ \\
\hline Valino Island & VALa & Bag 1 & N/A & 248 & $\begin{array}{l}46.93 \\
(14.76)\end{array}$ & $\begin{array}{l}32.46 \\
(10.72)\end{array}$ & $\begin{array}{l}10.97 \\
(3.48)\end{array}$ & $\begin{array}{l}13.83 \\
(9.67)\end{array}$ \\
\hline Valino Island & VALa & Bag 2 & N/A & 217 & $\begin{array}{l}43.07 \\
(13.59)\end{array}$ & $\begin{array}{l}28.4 \\
(8.43)\end{array}$ & $\begin{array}{l}11.94 \\
(4.14)\end{array}$ & $\begin{array}{l}11.11 \\
(7.15)\end{array}$ \\
\hline Valino Island & VALb & Bag 1 & N/A & 203 & $\begin{array}{l}49.51 \\
(14.92)\end{array}$ & $\begin{array}{l}31.93 \\
(11.61)\end{array}$ & $\begin{array}{l}10.98 \\
(3.74)\end{array}$ & $\begin{array}{l}14.38 \\
(9.38)\end{array}$ \\
\hline Valino Island & VALb & Bag 2 & N/A & 256 & $\begin{array}{l}46.09 \\
(14.58)\end{array}$ & $\begin{array}{l}29.9 \\
(9.91)\end{array}$ & $\begin{array}{l}12.28 \\
(3.75)\end{array}$ & $\begin{array}{l}12.73 \\
(7.78)\end{array}$ \\
\hline Valino Island & VALc & Bag 1 & N/A & 363 & $\begin{array}{l}48.64 \\
(16.14)\end{array}$ & $\begin{array}{l}32.51 \\
(9.93)\end{array}$ & $\begin{array}{l}10.72 \\
(3.17)\end{array}$ & $\begin{array}{l}13.82 \\
(7.05)\end{array}$ \\
\hline Valino Island & VALc & Bag 2 & N/A & 392 & $\begin{array}{l}51.31 \\
(14.78)\end{array}$ & $\begin{array}{l}33.81 \\
(7.71)\end{array}$ & $\begin{array}{l}14.53 \\
(3.67)\end{array}$ & $\begin{array}{l}12.66 \\
(6.44)\end{array}$ \\
\hline Westport & WESTa & Bag 1 & N/A & 425 & $\begin{array}{l}40.83 \\
(11.63)\end{array}$ & $\begin{array}{l}29.87 \\
(9.63)\end{array}$ & $\begin{array}{l}11.53 \\
(3.47)\end{array}$ & $\begin{array}{l}10.63 \\
(6.78)\end{array}$ \\
\hline Westport & WESTa & Bag 2 & N/A & 578 & $\begin{array}{l}45.37 \\
(12.07)\end{array}$ & $\begin{array}{l}32.45 \\
(8.45)\end{array}$ & $\begin{array}{l}11.5 \\
(3.53)\end{array}$ & $\begin{array}{l}13.07 \\
(6.26)\end{array}$ \\
\hline Westport & WESTb & Bag 1 & N/A & 445 & $\begin{array}{l}44.68 \\
(14.22)\end{array}$ & $\begin{array}{l}29.61 \\
(8.7)\end{array}$ & $\begin{array}{l}11.16 \\
(2.94)\end{array}$ & $\begin{array}{l}11.05 \\
(5.84)\end{array}$ \\
\hline Westport & WESTb & Bag 2 & N/A & 516 & $\begin{array}{l}43.02 \\
(12.17)\end{array}$ & $\begin{array}{l}27.92 \\
(7.79)\end{array}$ & $\begin{array}{l}10 \\
(2.94)\end{array}$ & $\begin{array}{l}10.02 \\
(5.81)\end{array}$ \\
\hline
\end{tabular}

Table A3. Fouling organisms (FOs) present in oyster bags collected in April and July 2017. For the July bags, the three most abundant FOs were identified. In some instances, only one or two dominant fouling organisms were identified.

\begin{tabular}{lllll}
\hline Site & Rack & Bag & Top 3 FOs & Remaining FOs \\
\hline April & & & & \\
\hline
\end{tabular}




\begin{tabular}{|c|c|c|c|c|}
\hline Coos Bay & COOSa & Bag 1 & Not identified & $\begin{array}{l}\text { Barnacles, bryozoan, crabs, } \\
\text { isopods, mussels }\end{array}$ \\
\hline Coos Bay & $\mathrm{COOSb}$ & Bag 1 & Not identified & $\begin{array}{l}\text { Amphipods, barnacles, bryozoan, } \\
\text { crabs, isopods, mussels, } \\
\text { polychaetes }\end{array}$ \\
\hline Coos Bay & COOSc & Bag 1 & Not identified & $\begin{array}{l}\text { Amphipods, barnacles, bryozoan, } \\
\text { crabs, isopods, mussels, } \\
\text { polychaetes }\end{array}$ \\
\hline North Bend & $\mathrm{NBa}$ & Bag 1 & Not identified & $\begin{array}{l}\text { Anemone, barnacle, bryozoan, } \\
\text { crab, mussel, polychaete }\end{array}$ \\
\hline North Bend & $\mathrm{NBb}$ & Bag 1 & Not identified & $\begin{array}{l}\text { Amphipods, barnacles, crabs, } \\
\text { limpet, mussels, polychaetes }\end{array}$ \\
\hline North Bend & $\mathrm{NBc}$ & Bag 1 & Not identified & $\begin{array}{l}\text { Barnacles, bryozoan, crabs, } \\
\text { isopods, mussels }\end{array}$ \\
\hline North Bend & NBd & Bag 1 & Not identified & $\begin{array}{l}\text { Barnacles, bryozoans, crabs, } \\
\text { mussels, polychaetes }\end{array}$ \\
\hline Netarts Bay & NETa & Bag 1 & Not identified & $\begin{array}{l}\text { Amphipods, barnacles, bryozoan, } \\
\text { crabs, mussels, polychaetes }\end{array}$ \\
\hline Netarts Bay & NETb & Bag 1 & Not identified & $\begin{array}{l}\text { Amphipods, barnacles, bryozoan, } \\
\text { crabs, isopods, mussels, tunicate }\end{array}$ \\
\hline Netarts Bay & NETc & Bag 1 & Not identified & $\begin{array}{l}\text { Amphipods, barnacles, bryozoan, } \\
\text { crabs, gastropod, mussels, } \\
\text { polychaetes }\end{array}$ \\
\hline Valino Island & VALa & Bag 1 & Not identified & $\begin{array}{l}\text { Amphipods, barnacles, bryozoan, } \\
\text { crabs, mussels, tunicate, } \\
\text { polychaetes }\end{array}$ \\
\hline Valino Island & VALb & Bag 1 & Not identified & $\begin{array}{l}\text { Amphipods, barnacles, bryozoan, } \\
\text { crabs, isopods, mussels, } \\
\text { polychaetes }\end{array}$ \\
\hline Valino Island & VALc & Bag 1 & Not identified & $\begin{array}{l}\text { Amphipods, barnacles, bryozoan, } \\
\text { crabs, mussels, polychaetes }\end{array}$ \\
\hline Westport & WESTa & Bag 1 & Not identified & $\begin{array}{l}\text { Amphipods, barnacles, bryozoan, } \\
\text { crabs, hermit crabs, macroalgae, } \\
\text { mussels, nudibranch, polychaetes }\end{array}$ \\
\hline Westport & WESTb & Bag 1 & Not identified & $\begin{array}{l}\text { Amphipods, barnacles, bryozoan, } \\
\text { crabs, hermit crabs, macroalgae, } \\
\text { mussels, polychaetes }\end{array}$ \\
\hline \multicolumn{5}{|l|}{ July } \\
\hline Coos Bay & COOSa & Bag 1 & $\begin{array}{l}\text { Amphipods, barnacles, } \\
\text { bryozoan }\end{array}$ & $\begin{array}{l}\text { Crabs, isopods, mussels, } \\
\text { polychaetes }\end{array}$ \\
\hline Coos Bay & COOSa & Bag 2 & $\begin{array}{l}\text { Amphipods, barnacles, } \\
\text { bryozoan }\end{array}$ & $\begin{array}{l}\text { Crabs, isopods, macroalgae, } \\
\text { polychaetes }\end{array}$ \\
\hline Coos Bay & COOSb & Bag 1 & $\begin{array}{l}\text { Barnacles, bryozoan, } \\
\text { microalgae }\end{array}$ & $\begin{array}{l}\text { Amphipods, crabs, isopods, } \\
\text { mussels }\end{array}$ \\
\hline Coos Bay & $\mathrm{COOSb}$ & Bag 2 & $\begin{array}{l}\text { Barnacles, bryozoan, } \\
\text { isopods }\end{array}$ & Amphipods, mussels, polychaetes \\
\hline North Bend & $\mathrm{NBa}$ & Bag 1 & $\begin{array}{l}\text { Bryozoan, mussels, } \\
\text { polychaetes }\end{array}$ & Tunicates, crabs \\
\hline North Bend & $\mathrm{NBa}$ & Bag 2 & $\begin{array}{l}\text { Barnacles, bryozoan, } \\
\text { mussels }\end{array}$ & Polychaetes \\
\hline North Bend & $\mathrm{NBb}$ & Bag 1 & $\begin{array}{l}\text { Barnacles, bryozoan, } \\
\text { mussels }\end{array}$ & Crabs, polychaetes \\
\hline
\end{tabular}




\begin{tabular}{|c|c|c|c|c|}
\hline North Bend & $\mathrm{NBb}$ & Bag 2 & $\begin{array}{l}\text { Barnacles, bryozoan, } \\
\text { mussels }\end{array}$ & $\begin{array}{l}\text { Amphipods, crabs, limpets, } \\
\text { polychaetes }\end{array}$ \\
\hline North Bend & $\mathrm{NBc}$ & Bag 1 & $\begin{array}{l}\text { Barnacles, bryozoan, } \\
\text { crabs }\end{array}$ & Amphipods, limpets, polychaetes \\
\hline North Bend & $\mathrm{NBc}$ & Bag 2 & $\begin{array}{l}\text { Barnacles, bryozoan, } \\
\text { mussels }\end{array}$ & Crabs, isopods, polychaetes \\
\hline North Bend & NBd & Bag 1 & $\begin{array}{l}\text { Barnacles, bryozoan, } \\
\text { mussels }\end{array}$ & Crabs, polychaetes \\
\hline North Bend & NBd & Bag 2 & $\begin{array}{l}\text { Barnacles, mussels, } \\
\text { polychaetes }\end{array}$ & Crabs \\
\hline Netarts Bay & NETa & Bag 1 & Barnacles, mussels & Crabs, isopods, polychaetes \\
\hline Netarts Bay & NETa & Bag 2 & $\begin{array}{l}\text { Amphipods, barnacles, } \\
\text { microalgae }\end{array}$ & Mussels \\
\hline Netarts Bay & $\mathrm{NETb}$ & Bag 1 & Barnacles & Isopods, mussels \\
\hline Netarts Bay & NETb & Bag 2 & Barnacles, tunicate & $\begin{array}{l}\text { Amphipods, crabs, mussels, } \\
\text { polychaetas, sponge }\end{array}$ \\
\hline Netarts Bay & NETc & Bag 1 & Barnacles & Microalgae, mussels, polychaetes \\
\hline Netarts Bay & NETc & Bag 2 & Barnacles, microalgae & Amphipods, polychaetes \\
\hline Valino Island & VALa & Bag 1 & Barnacles, bryozoan & Amphipods, mussels, polychaetes \\
\hline Valino Island & VALa & Bag 2 & $\begin{array}{l}\text { Barnacles, bryozoan, } \\
\text { mussels }\end{array}$ & $\begin{array}{l}\text { Amphipods, bryozoan, crabs, } \\
\text { isopods, polychaetes }\end{array}$ \\
\hline Valino Island & VALb & Bag 1 & $\begin{array}{l}\text { Barnacles, bryozoan, } \\
\text { mussels }\end{array}$ & $\begin{array}{l}\text { Amphipods, isopods, crabs, } \\
\text { polychaetes, sponge }\end{array}$ \\
\hline Valino Island & VALb & Bag 2 & Barnacles, bryozoan & $\begin{array}{l}\text { Amphipods, crabs, mussels, } \\
\text { polychaetes, sponge }\end{array}$ \\
\hline Valino Island & VALc & Bag 1 & Barnacles, bryozoan & $\begin{array}{l}\text { Amphipods, crabs, mussels, } \\
\text { polychaetes }\end{array}$ \\
\hline Valino Island & VALc & Bag 2 & $\begin{array}{l}\text { Barnacles, bryozoan, } \\
\text { crabs }\end{array}$ & $\begin{array}{l}\text { Amphipods, microalgae, mussels, } \\
\text { nudibranch }\end{array}$ \\
\hline Westport & WESTa & Bag 1 & $\begin{array}{l}\text { Barnacles, bryozoan, } \\
\text { isopods }\end{array}$ & $\begin{array}{l}\text { Hermit crabs, macroalgae, mussels, } \\
\text { polychaetes }\end{array}$ \\
\hline Westport & WESTa & Bag 2 & $\begin{array}{l}\text { Barnacles, bryozoan, } \\
\text { isopods }\end{array}$ & Hermit crabs, polychaetes \\
\hline Westport & WESTb & Bag 1 & $\begin{array}{l}\text { Barnacles, bryozoan, } \\
\text { polychaetes }\end{array}$ & $\begin{array}{l}\text { Amphipods, isopods, microalgae, } \\
\text { mussels }\end{array}$ \\
\hline Westport & WESTb & Bag 2 & $\begin{array}{l}\text { Barnacles, isopods, } \\
\text { polychaetes }\end{array}$ & $\begin{array}{l}\text { Bryozoan, hermit crabs, } \\
\text { microalgae, mussels }\end{array}$ \\
\hline
\end{tabular}

Appendix A4: Reflections on what I have learned from this field study (requested by dissertation committee)

When I conducted this field experiment, there were some things I could have done differently to improve the outcomes of the research. Therefore, this work was a learning experience for future studies. Below is a list of lessons that I would implement in future research: 


\section{Lesson 1: Scope out field sites in advance}

When I planned this study, I chose to compare sites near wastewater and aquaculture in OR and WA. To identify appropriate wastewater sites, I searched for places with outfalls and adjacent mudflat (suitable habitat for oysters) using Google Earth, internet sources, and personal communication with agency staff from Oregon and Washington Departments of Fish and Wildlife (ODFW/WDFW) and the South Slough National Estuarine Research Reserve (NERRS). However, I did not visit all of the chosen sites before setting up the experiment. I had limited research funding that was only enough to pay for the supplies and travel to set things up and take them down the following year, but did not allow for an additional site scoping trip. I also had a deadline to spend this money and needed to set up the experiment by July 2016. I was able to visit one site (Netarts Bay) thanks to ODFW taking me on a day trip while they conducted field work. This visit resulted in the setup going relatively smoothly and as planned. When I got to Grays Harbor, WA and Coos Bay, OR, I ran into several issues, mainly due to my unfamiliarity with the proposed sites and having to rush to make decisions about the study. Upon reflection of this field work, I think it would have been worth the time, effort, and perhaps revisiting the budget to visit the sites beforehand and plan the study accordingly in advance. If I conduct future field work, I now recognize the importance of this step and would be very hesitant to start a field study without visiting the proposed and potential backup sites first.

Lesson 2: Implement randomization and replication at the right level into the field design 
The overarching goal of this study was to look at effects and concentrations of PPCPs along a pollution gradient, and also compare wastewater and oyster growout sites. While I had ample replication of individual oysters at each rack, the replication at the site level could have been improved to draw higher order conclusions about exposure to wastewater. Ideally, there should have been an even number of site types (wastewater and oyster growout), at least three replicates of each site type, and randomly chosen sites. More specifically, multiple appropriate sites should have been identified, and then a few randomly chosen from each category. I do think that having racks at multiple distances from the outfall may be helpful in examining small scale spatial variation, but these distances should be the same at every outfall for better comparison. This was not possible at the sites I chose, but this could potentially be fixed with improved site identification (as discussed above). Lastly, it is important to consider data analysis from the beginning of the experiment. I had little experience in this area and would have benefited from taking the ESM univariate data analysis course in my first year, something I often recommend to incoming graduate students, or consulting with an expert (e.g., Dr. Pan).

\section{Lesson 3: Utilize consistent sampling when comparing seasons}

In this experiment, I planned to compare oyster growth and health between two seasons, spring and summer. I wasn't able to do this effectively because the oysters I collected in the spring were too small/brittle to separate without breaking most of them. Therefore, I couldn’t get an adequate sample to measure mass and condition index. Originally, I only had funding to run PPCP analyses on spring samples, but I acquired 
some additional funding to analyze some summer samples, though not enough to repeat the same sampling. So instead I ran analyses for different compounds at a few sites. While this resulted in some interesting findings, it was impossible to compare to the spring samples. This was an unfortunate situation, primarily driven by funding, and it is difficult to say what I could have done differently, but in the future, I would certainly consider the importance of having consistent sampling data when comparing seasons.

\section{Lesson 4: Collaborate with stakeholders}

The one thing that made this work successful was collaboration with stakeholders. I relied heavily on advice and field assistance from experts working in marine science and management in OR and WA. Being a student at inland PSU made it especially challenging to do coastal field work, but partnerships with agency staff made it happen. These experiences really emphasized the importance of collaboration in science and I would hesitate to do any coastal research without consulting stakeholders. Additionally, I think it would have been beneficial to consult with more diverse stakeholders about the research questions and study design.

These important lessons have allowed me to reflect on how I would do this experiment differently with the knowledge I have now, and with increased resources. If I were to redo this experiment, and had the resources to make improvements, I would:

- Identify all possible wastewater and oyster growout sites in OR and WA

- Randomly choose 5 (or more) sites of each type (wastewater/oyster growout)

- Visit potential sites to make sure they are adequate for the field design 
- If not, identify backup sites or adjust study design to be consistent across sites

- At wastewater sites, make sure I could put the first oyster rack at the same distance from each outfall to compare wastewater to oyster growout, and put remaining racks at consistent distances from the outfall

- Rather than placing racks at different distances at oyster growout sites, measure environmental covariates that could add confounding variation to the results

- Reach out to more stakeholders for input on research objectives and study design 


\section{Appendix B: Supporting tables, figures, and information for chapter 3}

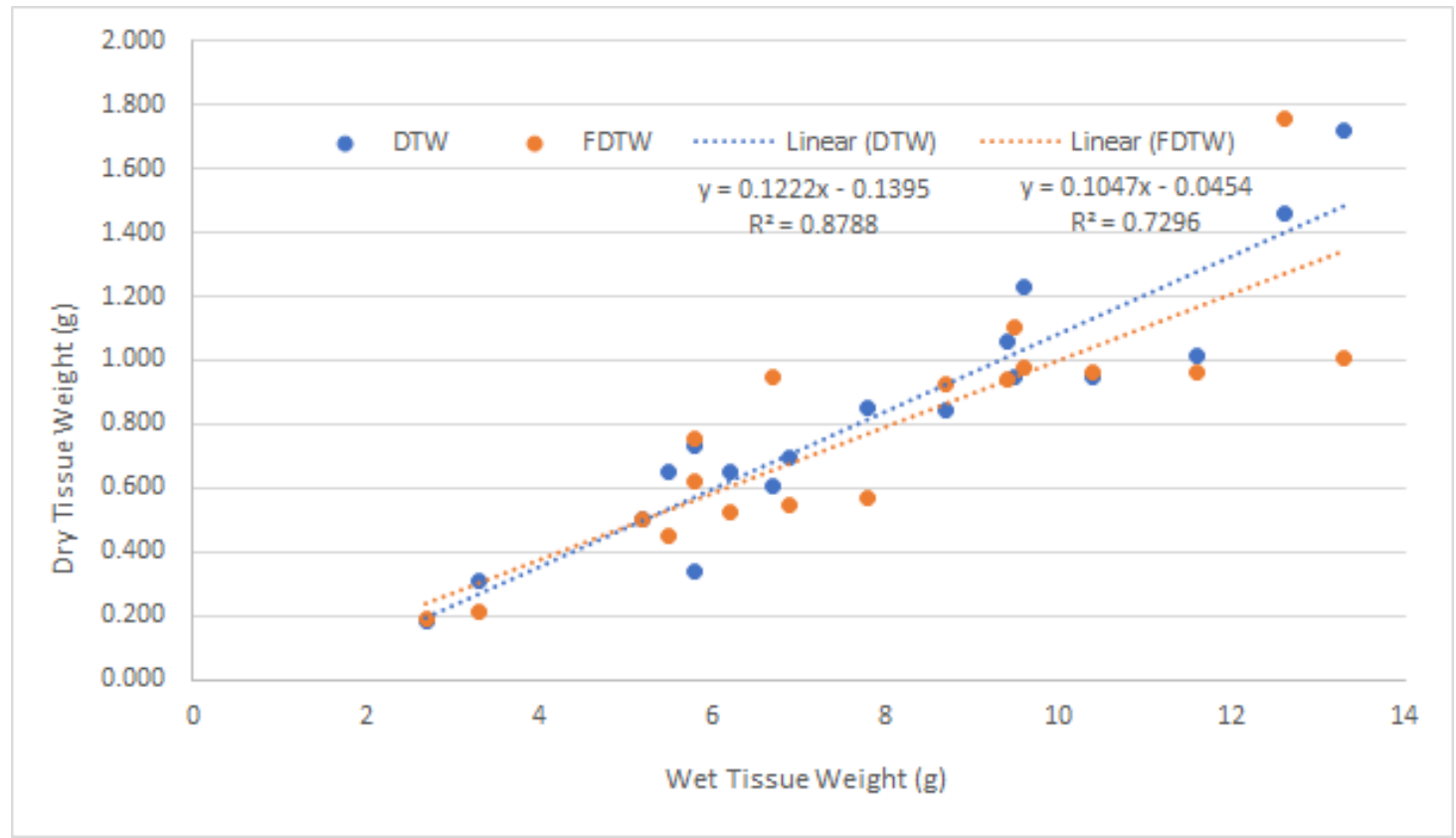

Figure B1. Comparison of oven dried tissue weights (DTW) and freeze dried tissue weights (FDTW) of oysters with similar wet tissues weights.

Appendix B2: Summary of lab experiment challenges (requested by dissertation committee)

This lab experiment had many external challenges and unforeseen issues that influenced the experimental design and data collection. First of all, it was difficult to get two treatment plants on board for a full experiment. One treatment plant operator agreed to provide effluent for 12 weeks, and then asked to be recused from the experiment after the third week. At that point, I did not have enough funding or resources to start the experiment over and therefore had to replace the treatment plant with another.

Additionally, I planned the experiment to take place during the summer tourist season, which would have higher human populations and lower rain events with resulting sewer overflows. Changing the timing of the experiment could have affected the results more 
than switching the treatment plant early in the experiment. Secondly, both treatment plants were able to provide a very limited amount of composite effluent, which resulted in using small tanks with small/slow filters, and fewer organisms per tank (lower replication) to get the desired effluent dilutions (10\% and 25\%). With two tanks in our lab not in working condition and no budget to fix them, there were not enough to include a 50\% effluent exposure from both treatment plants, resulting in an unbalanced design. Because of the small tanks with low flow filters, and malfunctions with the Coulter cell counter, the feeding rate trials resulted in inconsistent algal clearance rate data. Lastly, gaining access to a reliable freeze drier was exceedingly difficult and took months of searching, coordinating, setting up a machine and testing the methods. I spent several weeks working with USGS (emails, meetings, taking online and in-person lab safety assessments) to find out that their freeze drier could not handle the capacity of samples that I needed to run. Eventually I learned that a former professor in our department (Dr. Strecker) had an available freeze drier and I spent weeks setting it up and testing my methods. I started the process of finding a freeze drier in November 2019 and was preparing to dry my samples in March 2020, when covid-19 restrictions were put in place, further delaying the process.

Changes made to the experiment to troubleshoot these issues led to low replication, limited high effluent treatments, inadequate water flow, stressful tank conditions, different methods for oyster drying at different time points, and introducing potentially confounding factors (e.g., replacing WWTP2). Despite these challenges, the experiment ran for a full 12 weeks with low mortality. Oyster growth measurements were 
deemed reliable and some significant effects were identified. Effluent and tissue analysis resulted in several PPCP detections. Therefore, this experiment had some interesting outcomes and adds important information to the literature. 


\section{Appendix C: Supporting tables, figures, and information for chapter 4}

Appendix C1: Pharmacist answers to question about co-workers' attitudes regarding drug take-back programs.

When asked about their co-workers' attitudes toward drug take-back programs, pharmacists generally felt that their co-workers agreed with their opinion. At locations with dropboxes, one pharmacist said their co-workers had no opinion, but all others said co-workers had positive attitudes and rarely mentioned issues or hindrances associated with drug take-back programs. At locations without dropboxes, pharmacists said their coworkers were supportive of drug take-back programs but were very likely to mention the many difficulties associated with dropboxes. Some commonly mentioned issues were a need for education, better and clearer options to recommend to customers, and consistent information from regulatory agencies. Two said this issue was not discussed among coworkers, and two said they did not know.

Figure C2. Customer survey questions.

PSU Public Opinion Survey Version $10.2 \quad$ Date Location

\section{Pharmaceutical Waste Drop-off}

This questionnaire is part of a pilot research study being conducted by Portland State University aimed to better understand public disposal practices around leftover pharmaceuticals (prescription and over the counter) in the greater Portland area. Thank you for consenting to participate by completing this brief questionnaire. The survey takes about 10 minutes to finish. If you have any questions or are interested in our results please contact Dr. Elise Granek (graneke@pdx.edu). Please note that your responses are anonymous and you are not identified in any way with this information.

\section{By participating in the survey you consent to participating in this interview (or} questionnaire) and have been made aware of the potential risks and benefits of participations. 
1. How did you get to the pharmacy today?

$\square$ By Car $\square$ By foot $\square$ By Bicycle $\square$ By Bus $\square$ Other

2. Home (primary residence) zip code:

3. Is this current pharmacy trip typical for you (in terms of location, time onsite)? $\square$ Yes $\square$ No

4. How many times have you been to the pharmacy in the last month? $\square 0 \quad \square 1 \quad \square 2-3 \quad \square$ 4-10 $\square$ more than 10

5. If you answered zero to question number 4 , then approximately how many trips to the pharmacy have you made in the last 6 months?
$\square 0 \quad \square$
$\square 2-3$
$\square$ 4-10
$\square$ more than 10

6. How many members of your household have used pharmaceuticals over the past 6 months?
$\square 0 \quad \square 1$
$\square$ 2-3 $\square$ 4-10

7. What is the main reason for your trip to the pharmacy today (choose one)?

$\square$ Pick up a new prescription

$\square$ Pick up a prescription refill

$\square$ Drop off left over medication

$\square$ Ask the pharmacist a question

$\square$ Other

Pharmaceutical Disposal: As mentioned above, the focus of this study is on disposal of leftover pharmaceuticals. The following question are about your knowledge and practices with your leftover medicine.

8. When you have leftover medications, what do you typically do with them? (choose one)

$\square$ Drop at a pharmaceutical drop location

$\square$ Return to pharmacy

$\square$ Flush down toilet

$\square$ Throw away in trash

$\square$ Store at home

$\square$ Other

8. What does your doctor, nurse or pharmacist typically tell you to do with leftover medications? 
$\square$ Drop at a drop location

$\square$ Return to pharmacy

$\square$ Flush down toilet

$\square$ Throw away in trash

$\square$ I have never been told what to do with them

$\square$ Other

10. If you wanted to find the information or instructions on how to dispose of unused medication where would you look?

$\square$ I would read the label on the medicine

$\square$ I would look it up online

$\square$ I would ask my pharmacist, nurse, or doctor

$\square$ Other

11. Drug take back boxes are a good way to dispose of unneeded pharmaceuticals. What are the main obstacles for you for using a drug take back drop box (choose one)?

$\square$ Until now, I didn't know about the drug take back box

$\square$ I never remember to bring them with me

$\square$ I take them somewhere else (e.g., the police station)

$\square$ I usually flush extra drugs down the drain or put them in the trash

$\square$ I keep them in case I need them in the future

$\square$ Other

12. Do you know where the nearest drug take back location is to you?

$\square$ YES $\square$ NO

If yes, please provide approximate name and location:

13. If you were asked, could you explain why it matters where left over pharmaceuticals are disposed of?

$\square$ YES $\square$ NO

If yes, what would you say:

Demographic Information: The following questions are designed to give us a better idea of the characteristics of visitors to this pharmacy. Please note that your responses are anonymous and you will not be identified in any way with this information. 
14. What is your age:
$\square 18$ to 24 years
$\square 25$ to 34 years
$\square 35$ to 44 years
$\square 45$ to 54 years
$\square 55$ to 64 years
$\square 65$ to 74 years
$\square 75$ years and over

15. Do you identify as: $\square$ Male $\quad \square$ Female $\square$ Other

\section{Race/Ethnicity (choose all that apply):}

$\square$ White

$\square$ Hispanic or Latino

$\square$ Black or African American

$\square$ American Indian or Alaskan Native

$\square$ Pacific Islander

$\square$ Indian/South Asian

$\square$ Chinese

$\square$ Filipino

$\square$ Japanese

$\square$ Korean

$\square$ Vietnamese

$\square$ Other Asian

$\square$ Other

17. What is your highest level of education completed (choose only one):

$\square$ No formal education $\square$ Elementary/Junior High

$\square$ High School or Diploma $\square$ Vocational School $\square$ Some College

$\square$ Associates Degree $\quad \square$ Four-year College $\square$ Graduate School

18. Including yourself, how many people live in your current household?
$\square 1$
$\square 2$
$\square 3$
$\square 4$
$\square 5$
$\square 6-7 \quad \square 8-9$
10 or more

19. What was your total annual household income for the 2016 calendar year before taxes:

$\begin{array}{lll}\square \text { Less than } \$ 10,000 & \square \$ 10,000 \text { to } \$ 14,999 & \square \$ 15,000 \text { to } \$ 24,999 \\ \square \$ 25,000 \text { to } \$ 34,999 & \square \$ 35,000 \text { to } \$ 49,999 & \square \$ 50,000 \text { to } \$ 74,999 \\ \square \$ 75,000 \text { to } \$ 99,999 & \square \$ 100,000 \text { to } \$ 149,999 & \square \$ 150,000 \text { or more }\end{array}$ 


\section{Appendix D: PPCP Analyte Lists}

Figure D1. SGS AXYS PPCPs list 1 analyte list.

\begin{tabular}{|l|l|}
\hline \multicolumn{2}{|c|}{$\begin{array}{r}\text { PPCP List } 1 \text { - APOS } \\
\text { (Acid extraction, positive E SI) }\end{array}$} \\
\hline Acetaminophen & Norfloxacin \\
\hline Azithromycin & Norgestimate \\
\hline Caffeine & Ofloxacin \\
\hline Carbadox & Ormetoprim \\
\hline Carbamazepine & Oxacillin ${ }^{1}$ \\
\hline Cefotaxime & Oxolinic acid \\
\hline Ciprofloxacin & Penicillin $\mathrm{G}^{1}$ \\
\hline Clarithromycin & Penicillin V \\
\hline Clinafloxacin & Roxithromycin \\
\hline cloxacillin ${ }^{1}$ & Sarafloxacin \\
\hline Dehydronifedipine & Sulfachloropyridazine \\
\hline Digoxigenin & Sulfadiazine \\
\hline Digoxin & Sulfadimethoxine \\
\hline Dittiazem & Sulfamerazine \\
\hline 1,7-Dimethylxanthine & Sulfamethazine \\
\hline Diphenhydramine & Sulfamethiz ole \\
\hline Enrofloxacin & Sulfamethoxaz ole \\
\hline Erythromycin & Sulfanilamide \\
\hline Flumequine & Sulfathiaz ole \\
\hline Fluoxetine & Thiabendaz ole \\
\hline Lincomycin & Trimethoprim \\
\hline Lomefloxacin & Tylosin \\
\hline Miconazole & Virginiamycin M1 \\
\hline \hline
\end{tabular}

Figure D2. SGS AXYS PPCPs list 3 analyte list.

\begin{tabular}{|l|l||}
\hline \multicolumn{2}{|c||}{$\begin{array}{c}\text { PPCP List 3 - ANEG } \\
\text { Aqueous, solid and tissue samples } \\
\text { (Acid extraction, negative ESI) }\end{array}$} \\
\hline Bisphenol A & 2-hydroxy-ibuprofen \\
\hline Furosemide & Ibuprofen \\
\hline Gem fibrozil & Naproxen \\
\hline Glipizide & Triclocarban \\
\hline Glyburide & Tric losan \\
\hline Hydrochlorothiazide & Warfarin \\
\hline \hline
\end{tabular}

